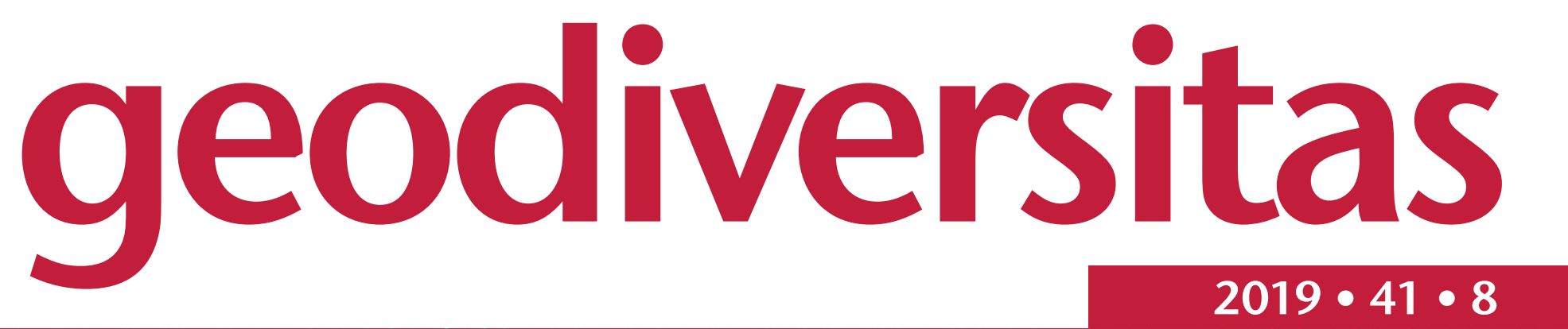

8). 310

1)

je

$\Delta$ eto

aldesto

\title{
Early Miocene Gastropods from the Felli Section (Proto-Mediterranean Sea, NW Greece)
}
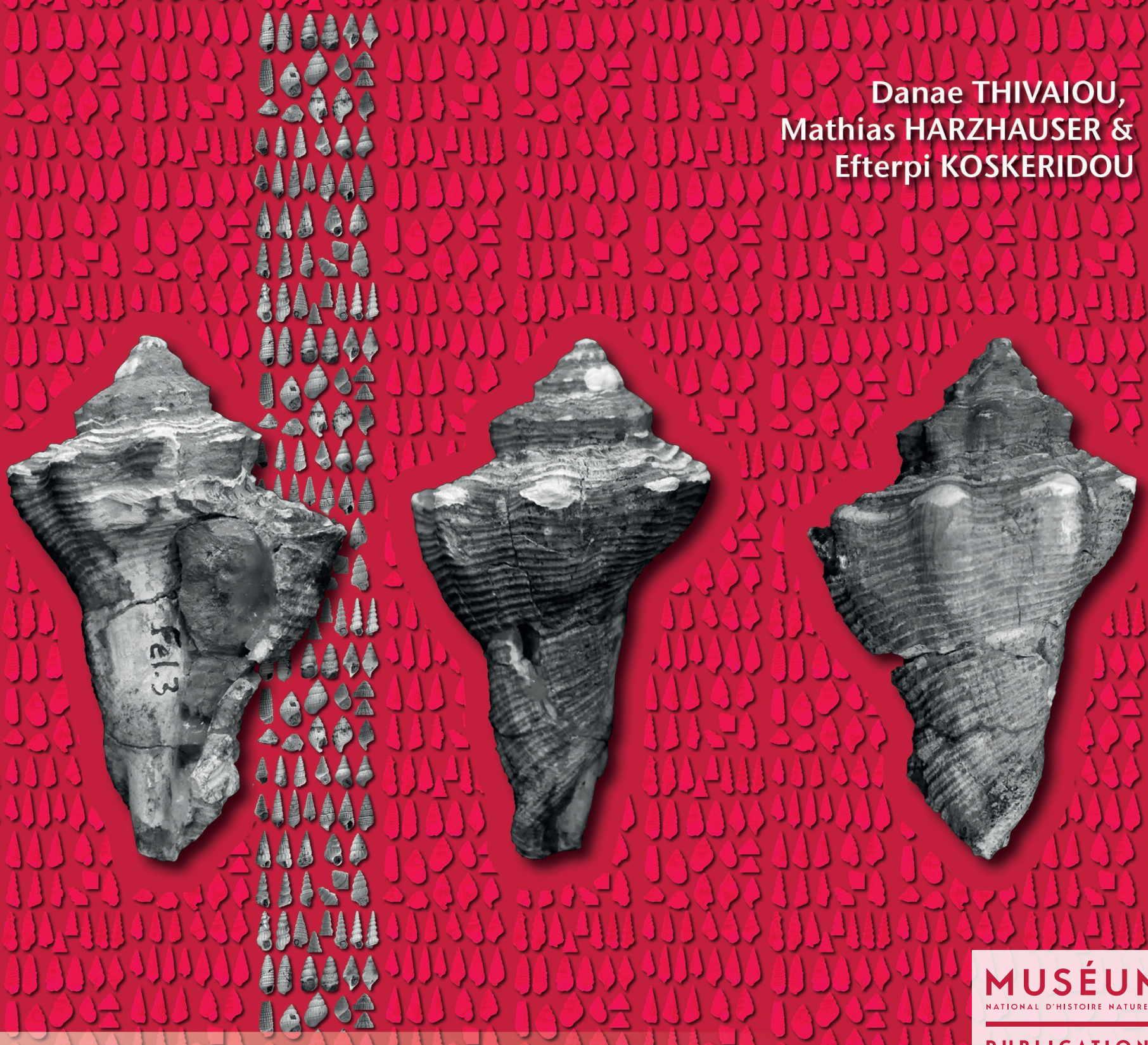
DiRECTEUR DE LA PUblication: Bruno David,

Président du Muséum national d'Histoire naturelle

RÉdACTEUR EN CHEF / EDITOR-IN-CHIEF: Didier Merle

ASSISTANTS DE RÉDACTION / ASSISTANT EDITORS: Emmanuel Côtez (geodiv@mnhn.fr)

Mise EN PAGE / PAGE LAYOUT: Emmanuel Côtez

COMITÉ SCIENTIFIQUE / SCIENTIFIC BOARD:

Christine Argot (MNHN, Paris)

Beatrix Azanza (Museo Nacional de Ciencias Naturales, Madrid)

Raymond L. Bernor (Howard University, Washington DC)

Alain Blieck (chercheur CNRS retraité, Haubourdin)

Henning Blom (Uppsala University)

Jean Broutin (UPMC, Paris)

Gaël Clément (MNHN, Paris)

Ted Daeschler (Academy of Natural Sciences, Philadelphie)

Bruno David (MNHN, Paris)

Gregory D. Edgecombe (The Natural History Museum, Londres)

Ursula Göhlich (Natural History Museum Vienna)

Jin Meng (American Museum of Natural History, New York)

Brigitte Meyer-Berthaud (CIRAD, Montpellier)

Zhu Min (Chinese Academy of Sciences, Pékin)

Isabelle Rouget (UPMC, Paris)

Sevket Sen (MNHN, Paris)

Stanislav Štamberg (Museum of Eastern Bohemia, Hradec Králové)

Paul Taylor (The Natural History Museum, Londres)

Couverture / COVER

Melongena lainei (de Basterot, 1825), AMPG(IV) 2467.

Geodiversitas est indexé dans / Geodiversitas is indexed in:

- Science Citation Index Expanded (SciSearch $\left.{ }^{\circledR}\right)$

- ISI Alerting Services ${ }^{\circledR}$

- Current Contents ${ }^{\circledR} /$ Physical, Chemical, and Earth Sciences ${ }^{\circledR}$

- Scopus ${ }^{\circledR}$

Geodiversitas est distribué en version électronique par / Geodiversitas is distributed electronically by:

- BioOne ${ }^{\circledR}$ (http://www.bioone.org)

Les articles ainsi que les nouveautés nomenclaturales publiés dans Geodiversitas sont référencés par / Articles and nomenclatural novelties published in Geodiversitas are referenced by:

- ZooBank ${ }^{\circledR}$ (http://zoobank.org)

Geodiversitas est une revue en flux continu publiée par les Publications scientifiques du Muséum, Paris Geodiversitas is a fast track journal published by the Museum Science Press, Paris

Les Publications scientifiques du Muséum publient aussi / The Museum Science Press also publish:

Adansonia, Zoosystema, Anthropozoologica, European Journal of Taxonomy, Naturae, Cryptogamie sous-sections Algologie, Bryologie, Mycologie.

Diffusion - Publications scientifiques Muséum national d'Histoire naturelle

CP $41-57$ rue Cuvier F-75231 Paris cedex 05 (France)

Tél. : 33 (0)1 40794805 / Fax: 33 (0)1 40793840

diff.pub@mnhn.fr / http://sciencepress.mnhn.fr

(C) Publications scientifiques du Muséum national d'Histoire naturelle, Paris, 2019

ISSN (imprimé / print): 1280-9659/ ISSN (électronique / electronic): 1638-9395 


\section{Early Miocene Gastropods from the Felli Section (Proto-Mediterranean Sea, NW Greece)}

Danae THIVAIOU

National and Kapodistrian University of Athens, University Campus 15784 Zografou (Greece) dthivaiou@geol.uoa.gr (corresponding author)

Mathias HARZHAUSER

Natural History Museum Vienna, Burgring 71010 Vienna (Austria) mathias.harzhauser@nhm-wien.ac.at

Efterpi KOSKERIDOU National and Kapodistrian University of Athens, University Campus 15784 Zografou (Greece) ekosker@geol.uoa.gr

KEY WORDS

Gastropoda,

Greece,

Miocene,

Neogene,

new combination,

new species.

\footnotetext{
MOTS CLÉS

Gastéropodes,

Miocène,

Grèce,

combinaison nouvelle,

espèces nouvelles.
}

Submitted on 5 July 2018 | accepted on 10 December 2018 | published on 15 April 2019
Thivaiou D., Harzhauser M. \& Koskeridou E. 2019. - Early Miocene Gastropods from the Felli Section (Proto-Mediterranean Sea, NW Greece). Geodiversitas 41 (8): 323-366. https://doi.org/10.5252/geodiversitas2019v41a8. http:// geodiversitas.com/41/8

\section{ABSTRACT}

The early Miocene mollusc faunas from the Proto-Mediterranean Sea are still poorly-known. Herein, Aquitanian gastropod assemblages from the Felli section in NW Greece are described. Two assemblages were recovered, a low-diversity coastal mudflat assemblage dominated by Granulolabium plicatum (Bruguière, 1792) and Mesohalina margaritacea (Brocchi, 1814), and a high-diversity marine assemblage dominated by Bittium larrieyense (Vignal, 1911). The marine assemblage yielded 44 species, of which three species are described as new and 23 are left in open nomenclature. A new combination is proposed for Finella perpusilla (Grateloup, 1827). The family Pyramidellidae is exceptionally represented by 15 species. 17 new occurences are reported for the Proto-Mediterranean Sea. Alvania amphitrite n. sp., Homalopoma acaste n. sp. and Pyramistomia aliakmoni n. sp. are introduced as new species.

\section{RÉSUMÉ}

Gastéropodes du Miocène inférieur de proto-Méditerrannée (NO de la Grèce).

Les mollusques du Miocène inférieur de Proto-Méditerannée sont peu connus. Une faune de gastéropodes de l'Aquitanien d'une section du NO de la Grèce y est décrite. Deux assemblages ont été déterminés, le premier présentant une faible diversité dans un environnement de vasière lagunaire et dominé par Granulolabium plicatum (Bruguière, 1792) et Mesohalina margaritacea (Brocchi, 1814), le second présentant une haute diversité d'environnement marin dominé par Bittium larrieyense (Vignal, 1911). L'assemblage marin est composé de 44 espèces, dont trois nouvelles et 23 laissées en nomenclature ouverte. Une nouvelle combinaison est proposée pour Finella perpusilla (Grateloup, 1827). La famille Pyramidellidae est exceptionnellement représentée par un total de 15 espèces. 17 nouvelles occurences sont signalées pour la Proto-Méditerrannée. Alvania amphitrite n. sp., Homalopoma acaste n. sp. et Pyramistomia aliakmoni n. sp. sont introduites comme nouvelles espèces. 


\section{INTRODUCTION}

The early Miocene marine mollusc faunas of the Eastern Mediterranean are relatively poorly known compared to the coeval faunas of the north-eastern Atlantic (Cossmann \& Peyrot 1909-1935; Lozouet et al. 2001; Lozouet 2014). This is partly due to the poor preservation of fossils in the Mediterranean region (Lozouet 2014) and the limited amount of available outcrops. The best documented early Miocene (Burdigalian) faunas from the proto-Mediterranean Sea were described in the late $19^{\text {th }}$ century from the Turin Hills in northern Italy (Sacco 1888, 1892, 1895a, b, 1896, 1897; Zunino \& Pavia 2009).

During the last decades, additional occurrences were reported from various basins in Turkey (İslamoğlu \& Taner 2003; İslamoğlu 2004; Mandic et al. 2004; Büyükmeriç 2017) and some localities in north-western Greece, with brackish water and marine species, have been reported by Harzhauser et al. (2002), Harzhauser \& Kowalke (2001) and WielandtSchuster et al. (2004).

The geographic position of the Greek part of the ProtoMediterranean Sea offers the possibility to trace species known from the north-eastern Atlantic Ocean and the Paratethys, as well as to assess their diversity and palaeogeographic dispersal (Harzhauser et al. 2002). Indeed, gastropod diversity plummets at the Paleogene/Neogene boundary as shown by well preserved faunas of the Aquitaine Basin of France (Lozouet 2014). This transition has yet to be assessed for the Proto-Mediterranean Sea, where few fossiliferous localities of Aquitanian age are known. In order to determine the effect of these climatic changes on the molluscan fauna, we investigated the Proto-Mediterranean deposits of the Mesohellenic Basin in north-western Greece. The aim of the present study is to report and describe gastropods of this age from northwestern Greece in order to contribute to the knowledge of the taxonomic composition and environmental conditions of the region.

\section{GEOLOGICAL SETTING}

This study deals with the Aquitanian gastropod fauna of the Pentalofos Formation of the Mesohellenic Basin (MHB, NW Greece). The MHB is a molasse basin active from the late Eocene to the middle Miocene (Ferrière et al. 2004; Zelilidis et al. 2002)narrow and elongated basin containing up to $c .5 \mathrm{~km}$ of Cenozoic sediments, which partially covers the tectonic boundary between the external, western zones (Pindos). It is composed of five main formations often rich in fossils (Wielandt-Schuster et al. 2004). The present material originates from the Pentalofos Formation, which consists of sandstone sediments of late Oligocene (Chattian) to the early Miocene (late Aquitanian-Burdigalian) age (Mavridis et al. 1985; Ferrière et al. 2004; Kilias et al. 2015; WielandtSchuster et al. 2004).

The section is mainly composed of sandy beds, fine conglomerates, and the top of the section is richer in finer particles (marls to clays). A change in sediment colour occurs between samples F9 and F10, going from darker to lighter colour and resulting in greenish clay for the topmost bed (sample F12).

The gastropods described here come from sandy marl (samples F1-F3 and F7-F8) to marly and clayey beds (samples F10-F12). Samples F4 to F6 contained scarce and fragmented shells whereas sample F9 was barren. No bivalves are preserved at the lower part of the section; samples F10-F12 contain fragmented bivalves of which few can be identified below family-level.

\section{MATERIAL AND METHODS}

Sampling was carried out at one small section, east of the village of Felli (Fig. 1), SE of Grevena City, by the river Aliakmon, where 12 bulk samples were taken (samples F1-F12). Two specimens of Melongena lainei were picked by hand at the lower part of the section. About $1 \mathrm{~kg}$ of the bulk samples were sieved using a $250 \mu \mathrm{m}$ size mesh in order to retrieve small-sized molluscs.

Taxonomy follows Bouchet et al. (2017).

Hierarchical cluster analysis (Fig. 2) was performed using RStudio version 1.1.453 with the Vegan package version 2.4-4. For this analysis, all gastropods and bivalves from the sieved samples that were identifiable up to the family-level were used.

\section{RESULTS AND DISCUSSION}

The best preserved specimens are described, including a new species of the family Pyramidellidae, a new species of the genus Alvania Risso, 1826 and three are left in open nomenclature, probably representing new species. The most abundant species is Bittium larrieyense Vignal, 1911, whereas the most diverse family is Pyramidellidae, which is represented by 15 species. In total, 17 species are reported for the first time in this part of the Proto-Mediterranean.

Two assemblages are recovered: 1) characterising a coastal mudflat environment; and 2) characterising a shallow marine environment. The differences between the two assemblages are clearly illustrated in a hierarchical cluster analysis (Fig. 2). The coastal mudflat assemblage is clustered together (samples F2-F8), with richer samples F2 and F7 being more similar. The marine assemblage is composed of three samples with little variability. Sample F10 has a lower diversity, and samples F11 and F12 have more species in common.

Seven species from the brackish assemblage are in common with those reported by Harzhauser et al. (2002) in the Burdigalian of the Mesohellenic Basin, whereas most of the marine gastropods mentioned therein have not been found in the present assemblages (perhaps due to different preservation conditions in the particular study section or due to a different paleoenvironmental setting).

\section{COASTAL MUDFLAT}

For the coastal mudflat assemblage, Granulolabium plicatum is the most abundant species followed by Mesohalina marga- 


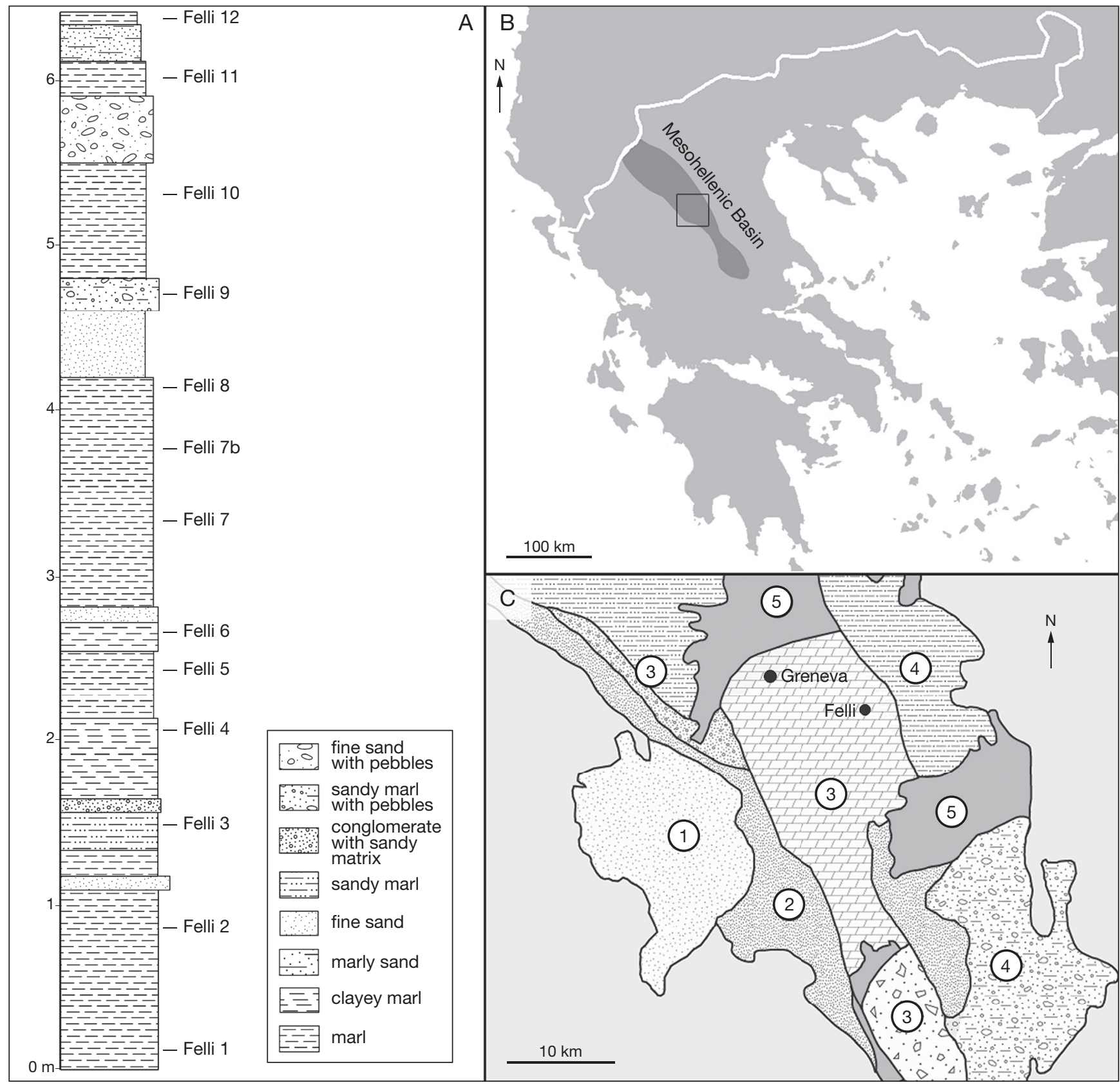

FIG. 1. - A, Lithostratigraphic column of the section of Felli; B, Geographical map of Greece and the Mesohellenic Basin; square indicates sampling area; C, Geological map of the studied area. Numbers: 1, Krania formation (Eocene); 2, Eptachori formation (lower-upper Oligocene); 3, Pentalofos formation (upper Oligocene-lower Miocene); 4, Tsotyli Formation (middle Miocene); 5, Quaternary. (Modified after Zelilidis et al. 2002).

ritacea and Vitta picta. Recent species of Potamididae inhabit coastal environments usually associated with mangrove environments (Reid et al. 2008).

The extant species Granulolabium diemenensis is able to withstand higher salinities associated with tidal flats with permanent water flow (Lozouet et al. 2001). On the other hand, recent podamidids (Tympanotonos, Telescopium and Terebralia) inhabit similar microhabitats within mangroves (Reid et al. 2008). The family Neritidae, represented here by Vitta picta, has free-swimming larvae developing in marine environments, and adults that inhabit lower reaches of streams as well as estuaries (Strong et al. 2008). Another relatively abundant species in this assemblage is Neritilia neritinoides (Cossmann \& Peyrot, 1918). This genus comprises recent species with very particular ecological needs, with adults living in freshwater environments with a proximity to the sea (Lozouet 2004), submarine caves, brackish estuaries and anchialine lakes (Kano et al. 2003), or freshwater streams (Kano \& Kase 2004) and larvae developing in saline environments (Symonds \& Tracey 2014).

In Felli, the specimens of Neritilia neritinoides (Cossmann \& Peyrot, 1917) are all fragmented, therefore transportation 
is inferred. This could also be the case for the freshwater gastropod Melanopsis sp., all specimens of which are always found, incomplete.

The gastropods of this assemblage point to a mudflat environment with patches of mangrove or at the fringe of the mangrove, with freshwater input.

\section{SHALLOW MARINE}

The shallow marine assemblage is largely dominated by Bittium larrieyense, followed by Finella perpusilla and Ringicula minor.

Modern representatives of Bittium feed on microalgae commonly occurring on seegrasses (Houbrick 1993), whereas Recent species of Ringicula are carnivores and have been recorded to feed on different species of benthic foraminifera (Chaban et al. 2017). The type species Finella pupoides A. Adams, 1860 lives on muds and muddy sands and more rarely on seagrasses (Janssen et al. 2011). Turritellidae are suspension feeders partially borrowed in sand (Allmon 2011). Extant Mediterranean species of Gibborissoia have been recorded to live on hard substrates (Öztürk et al. 2014), whereas G. varicosa seems to have been associated with seagrass environments (Lozouet et al. 2001).

The Rissoidae, represented here by two species, is a family whose members are usually found in shallow water depths with the majority of the species living on algae and sheltered environments (e.g. beneath stones or coral slabs); only a few species are found on the continental slopes and abyssal depths (Ponder 1984). In the Mediterranean Sea they are also reported from sands, muds and coralligenous algae (Bitlis \& Öztürk 2017). Species of the genus Alvania are known to be deposit feeders but also feed on benthic foraminifera (Ponder 1984).

The taxonomically most diverse family with moderate abundances is the parasitic family Pyramidellidae. Another moderately diverse group of gastropods of the assemblage is the Cephalaspidea represented by the families Retusidae, Rhizoridae and Cylichnidae. All three families are predators of diatoms and foraminifers, living in the top few centimetres of the sediment from mudflats to depths greater than $5500 \mathrm{~m}$ (Burn \& Thompson 1998). The family Columbellidae, represented in this fauna by Costoanachis cf. terebralis, live in shallow water environments, preferentially in rock or coral crevices, under stones, at the base of algae beds or associated with plant rhizomes (Oliverio 1995).

The most abundant species in this assemblage indicate a vegetated sandy environment. Accompanying fauna consists of species that live on hard bottoms such as Mathilda sp., Nodiscala cf. rugatina or Zebinella sp. This suggests the presence of elements that provide shelter, including vegetation elements (including seagrass rhizomes), rocks and corals. Coral remains were found in sample F11, thus confirming the information provided by the gastropod fauna.

Lastly, the presence of Smaragdia merignacensis is indicative of seagrasses as its modern representatives (Smaragdia viridis for example) are restricted to such environments (Rueda \& Salas 2007).

The species found in these Greek deposits are common in assemblages of the European Oligocene and Miocene, and the dominating species, Granulolabium plicatum and Mesohalina margaritacea, composing the mudflat assemblage are found from the NE Atlantic to the Paratethys and the Proto-Mediterranean (Lozouet et al. 2001; Harzhauser 2004; İslamoğlu 2004; Reid et al. 2008). In the fossil record, these species are believed to have inhabited shallow lagoons or saline inland lakes (Lozouet et al. 2001; Esu \& Girotti 2010); furthermore, $M$. margaritacea can be considered as an indicator of mangroves (Esu \& Girotti 2010) although usually it is known from brackish-lagoonal environments (Lozouet 2004). When associated with Granulolabium plicatum it implies a coastal mud flat (Harzhauser 2004).

Vitta picta has been reported in the Aquitanian of France as a species inhabiting the intertidal zone with low salinities or a freshwater influx (Cahuzac et al. 2012). In the brackish-lagoonal assemblages of the stratotype region of the Aquitanian, the most abundant species is Vitta picta, with Granulolabium plicatum and Mesohalina margaritacea being less abundant (Lozouet et al. 2001).

The association of Granulolabium plicatum, Mesohalina margaritacea, Vitta picta and Melanopsis sp. is known from multiple locations of the Western Tethys and the Paratethys as early as the Oligocene (Báldi 1973; İslamoğlu 2008). This association persists in the Western Tethys-Proto-Mediterranean until the Aquitanian for the same types of environments with fluviatile influence (İslamoğlu 2008). In Felli, this association also includes Neritilia neritinoides, which is a rarely reported species from the European Oligocene and Miocene, yet has been found with Melanopsis sp. in the Aquitaine Basin accompanied solely by freshwater species as Gyraulus balizacencis (Peyrot, 1931) and Hydrobia spp. (Lozouet 2004).

Comparable marine assemblages are found in the Aquitaine Basin, where the most abundant gastropod is Gibborissoia varicosa closely followed by Bittium larrieyense. The present assemblage has a similar composition and differs in abundances. Finella perpusilla is mostly known from the Paratethys where it can contribute up to $65 \%$ of shells in recovered tempestite beds (Zuschin et al. 2004). Ringicula species have been found in the Aquitaine Basin in muddy detrital assemblages (Lozouet 2004); in the Burdigalian Kerala Basin in India, Ringicula occur in seagrass samples (Harzhauser 2014). Associations of burrowing gastropods such as Pyrunculus sp. with Retusa truncatula, have been described in the Badenian of the Vienna Basin (Švagrovský 1984).

\section{CONCLUDING REMARKS}

Herein, we present a new assemblage of mainly small-sized gastropod species from the Aquitanian of the Mesohellenic Basin in NW Greece. Only very limited information on the Aquitanian mollusc fauna of the Proto-Mediterranean Sea was available so far and the preservation of the shells is usually very poor. Thus, the new material provides a rare opportunity to describe the taxonomic composition if this early Miocene fauna and to evaluate its paleoecological requirements and its paleobiogeographic significance. 


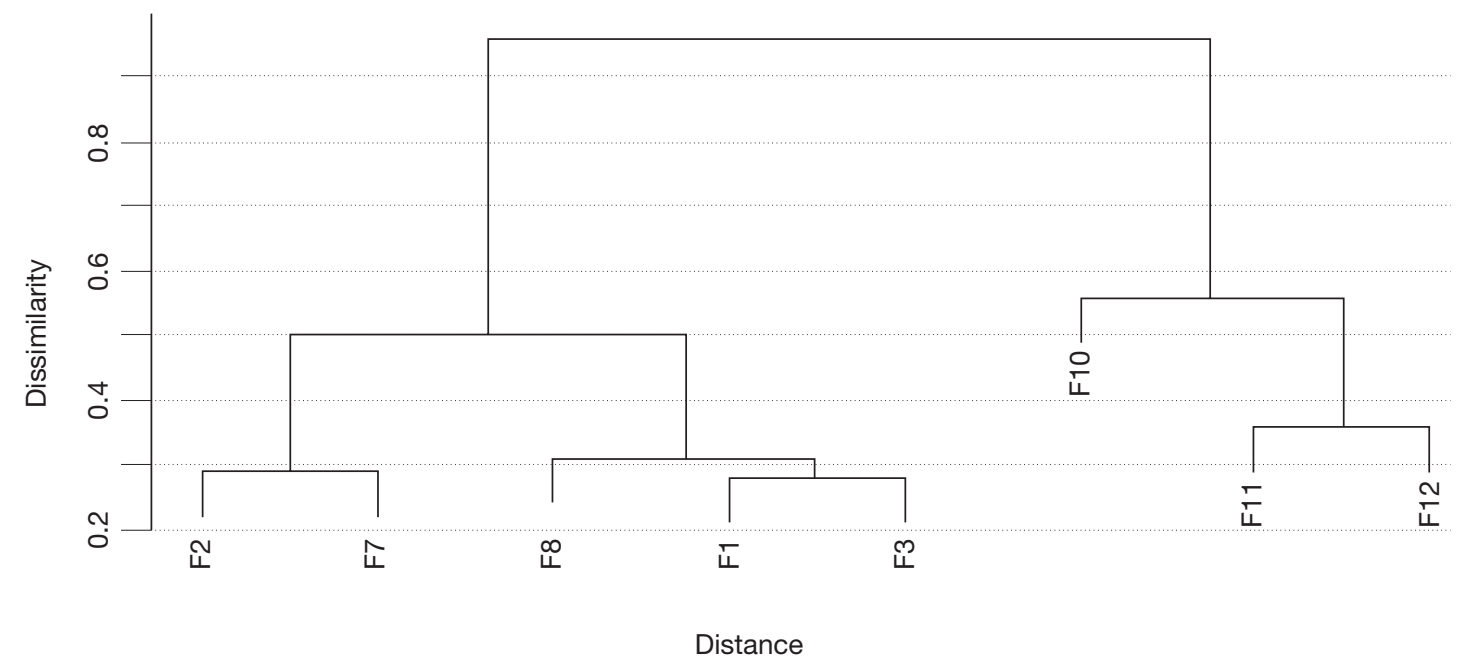

FIG. 2. - Hierarchal cluster analysis of the fossil-bearing samples of the section Felli. Distances were calculated using Bray-Curtis distances and single linkage.

\section{SYSTEMATIC PALAEONTOLOGY}

Subclass VETIGASTROPODA Salvini-Plawen, 1980

Order TROCHIDA Rafinesque, 1815

Superfamily TrochoideA Rafinesque, 1815

Family TROCHIDAE Rafinesque, 1815

Genus Paroxystele Schultz, 1969

TYPE SPECIES. - Trochus patulus Brocchi, 1814, by original designation. Late Miocene-Pliocene, Mediterranean Sea.

\section{Paroxystele orientale (Cossmann \& Peyrot, 1917)}

(Fig. 3A1-A4)

Oxystele orientalis Cossmann \& Peyrot, 1917: 102.

Paroxystele orientale - Landau et al. 2013: 28, pl. 1, fig. 8 (cum syn.).

Material EXAmined. - Sample F11: AMPG(IV) 1506-1508 (three specimens).

Dimensions. - Maximum height: $3.2 \mathrm{~mm}$ (incomplete); maximum diameter: $4.2 \mathrm{~mm}$.

Distribution. - Early Miocene. Paratethys: Austria (Schaffer 1912); Proto-Mediterranean Sea: Greece (this paper).

Middle Miocene. Proto-Mediterranean Sea: Turkey (Landau et al. 2013); Paratethys: Austria (Hörnes 1855), Poland (Bałuk 1975), Hungary (Strausz 1966).

\section{DESCRIPTION}

Protonch of about 150-160 $\mu$ m, corroded. First three teleoconch whorls high spired, later whorls much more flat-sided. Spiral sculpture of 10-11 spiral cords of alternating strength. Discrete axial sculpture present with inconspicuous growth lines giving a rough appearance in spaces between spiral cords; these growth lines become more prominent in later whorls, forming very fine lamellae. Umbilicus not preserved. Colour is preserved in all specimens, almost white apically, grading into darker orange-brown with some irregularly spaced white blotches in later whorls.

\section{REMARKS}

Although the specimens recovered are incomplete, the characters available are in agreement with the description of the species by Landau et al. (2013). Furthermore, a complete list of synonymy is provided by Landau et al. (2013), followed by a comparison with other Miocene species.

Species of Trochidae are commonly associated with hard substrata (Williams et al. 2010).

\section{Family COLlONIIDAE Cossmann, 1917 \\ Genus Homalopoma Carpenter, 1864}

TYPE SPECIES. - Turbo sanguineus Linnaeus, 1758, by original designation. Recent, Mediterranean Sea.

\section{Homalopoma acaste $\mathrm{n} . \mathrm{sp}$.}

(Fig. 3B1-B3)

urn:Isid:zoobank.org:act:59B2AFC6-2AF5-40BF-B619-5B3229CC64E8

TyPe Material. - Holotype: sample F11: AMPG(IV) 1512. — Paratype: sample F11: AMPG(IV) 1513.

OTHER MATERIAL EXAMINED. - Sample F10: AMPG(IV) 15091511 (three juveniles); sample F11: AMPG(IV) 1516, 1517 (two juveniles).

Dimensions. - Maximum height: $4.80 \mathrm{~mm}$; maximum diameter: $6 \mathrm{~mm}$.

Etymology. - Named after the Oceanid Acaste of Greek mythology, one of the companions of Persephone when abducted by Hades (as noun in apposition).

Type Locality. - Felli village section, $40^{\circ} 01^{\prime} 4.55^{\prime \prime} \mathrm{N}$, 2133’34.37”E. Mesohellenic Basin, Grevena area, Greece.

TyPe LEVEL. - Pentalofos Formation, Aquitanian, lower Miocene. 
DiAgnosis. - A small Homalopoma species, with a granulated aspect of the spiral sculpture on top of whorls, prominent spiral sculpture and an umbilicus with strongly crenulated edge.

Distribution. - Early Miocene. Proto-Mediterranean Sea: Greece (this paper).

\section{DESCRIPTION}

Shell small, solid, turbiniform. Teleoconch consisting of 3.5 slightly depressed convex whorls, suture impressed and linear. Spiral sculpture consists of four primary cords, adapical cord beaded to crenulated; four secondary spiral cords beneath the primary cords. Last whorl inflated, convex. Base with seven weakly granulose cords. Axial sculpture consists of very thin prosocline ribs. Aperture subcircular; umbilicus moderately wide, bordered by beaded edge.

\section{REMARKS}

In the present material the protoconch measures about 105 $\mu \mathrm{m}$ in all specimens. The colour patterns are still preserved as is often the case with other members of the genus in the Aquitaine Basin (Cossmann \& Peyrot 1917). The granulose appearance of the primary cords is irregular with weak beads of different sizes cords on the base of the shell having a more granulose aspect, whereas the cords adjacent to the umbilicus have larger but weaker beads. Two morphotypes were found in similar sandy sediments; they have the same spiral sculpture (number of primary and secondary cords) with one morphotype having more prominent, finer spiral cords, and more prominent axial sculpture.

The present Homalopoma differs from H. granulosa, a species from the Oligocene and Miocene of France (Lozouet et al. 2001), in having a granulose aspect in its spiral sculpture, a wider umbilicus, as well as wider spirals. Another species from the early Miocene (Burdigalian) of the Aquitaine region of France is $H$. degrangei (Cossmann \& Peyrot, 1917). It differs with the present species in having weak spiral sculpture and more convex whorls. Homalopoma laleensis Landau, Harzhauser, from the middle Miocene (Serravalian) of Turkey is smaller in size, has weak spiral sculpture and weaker umbilical crenulations.

Homalopoma includes hard-bottom dwellers and species that are adapted to cryptic environments (Lozouet 2004), including the type species $H$. sanguineum, which is frequent in Mediterranean submarine caves (Di Geronimo et al. 1997).

\author{
Subclass NERITIMORPHA \\ Golikov \& Starobogatov, 1975 \\ Order CYCLONERITIDA Frýda, 1998 \\ Superfamily HeLiCINOIDEA Férussac, 1822 \\ Family NeritiLIIDAE Schepman, 1908
}

Genus Neritilia Martens, 1879

Type SPECIES. - Neritina rubida Pease, 1865 , by monotypy. Recent, Indo-Pacific.
Neritilia neritinoides (Cossmann \& Peyrot, 1917)

(Fig. 3D1-D4)

Tinostoma (Megatyloma) neritinoides Cossmann \& Peyrot, 1917: 14 , no. 126 , pl. 7 , figs 11-13.

Agapilia picta - Harzhauser \& Kowalke 2001: 356, fig. 2/5-8 (non Férussac, 1823).

Neritilia neritinoides - Lozouet 2004: 450, fig. 3.

Material eXamined. - Sample F2: AMPG(IV) 1517-1533 (16 specimens); sample F3: AMPG(IV) 1534-1540 (seven specimens); sample F7: AMPG(IV) 1541-1542 (two specimens).

Dimensions. - Maximum height: $1.21 \mathrm{~mm}$ (incomplete), maximum diameter: $1.23 \mathrm{~mm}$.

Distribution. - Oligocene. NE Atlantic: France (Lozouet 2004). Early Miocene. NE Atlantic: France (Cossmann \& Peyrot 1917); Proto-Mediterranean Sea: Greece (this paper).

\section{REMARKS}

A complete description was provided by Lozouet (2004) in his review of the European Tertiary Neritiliidae, with remarks on this poorly known family of small gastropods. The most characteristic feature of the family is the structure of the protoconch, with a characteristic embryonic shell that has a different orientation to that of the rest of the protoconch; furthermore, it bears a semi-circular to circular scar and spiral ridges (Kano et al. 2003; Lozouet 2004). In $N$. neritinoides the protoconch has regularly-spaced minute pits, observable in the Greek specimens despite their poorer preservation compared to the well-preserved French specimens. Almost all of the specimens have a hyaline shell and a broken outer lip; the protoconch measures about $270 \mu \mathrm{m}$; the largest specimen measures approximately $1.20 \mathrm{~mm}$ in height.

$N$. neritinoides seems to be the most common species of the family during the early Miocene, being found in France as well as Greece. In recent species, the planktotrophic larval phase occurs in saline environments before returning to estuaries for settling and migrating upstream as juveniles after metamorphosis (Kano et al. 2003). This supports the dispersal of species through the saline-water barrier, thus explaining the dispersal of a single Miocene species throughout Europe.

Superfamily NERITOIDEA Rafinesque, 1815

Family Neritidae Rafinesque, 1815

Genus Vitta Mörch, 1852

TyPE SPECIES. - Nerita virginea Linnaeus, 1758; subsequent designation by Baker (1923). Recent, Western Atlantic.

Vitta picta (Férussac, 1823)

(Fig. 3C1-C4)

Neritina picta Férussac in Férussac \& Deshayes, 1823: pl. 2, figs 4-7.

Agapilia picta - Landau et al. 2013: 36, pl. 2, figs 11-14; pl. 54, fig. 7 (cum syn.). 


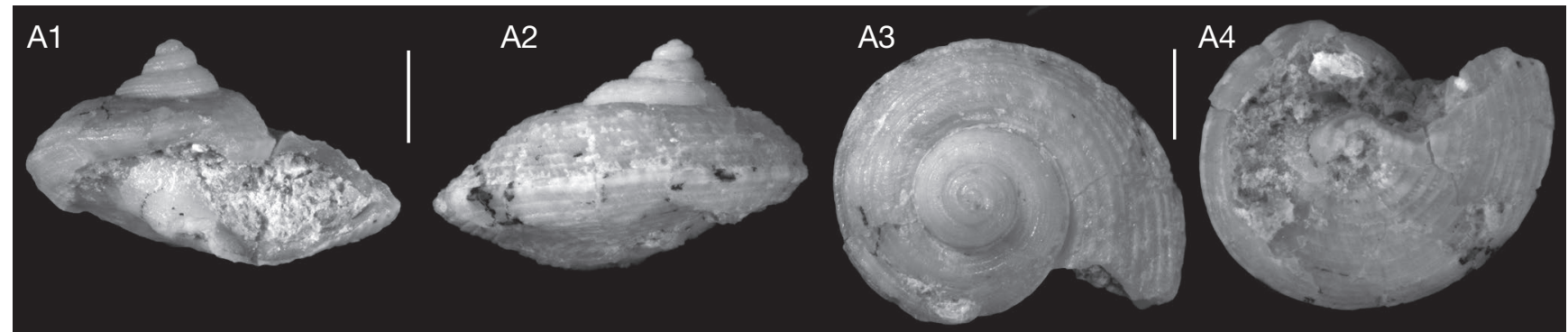

B1
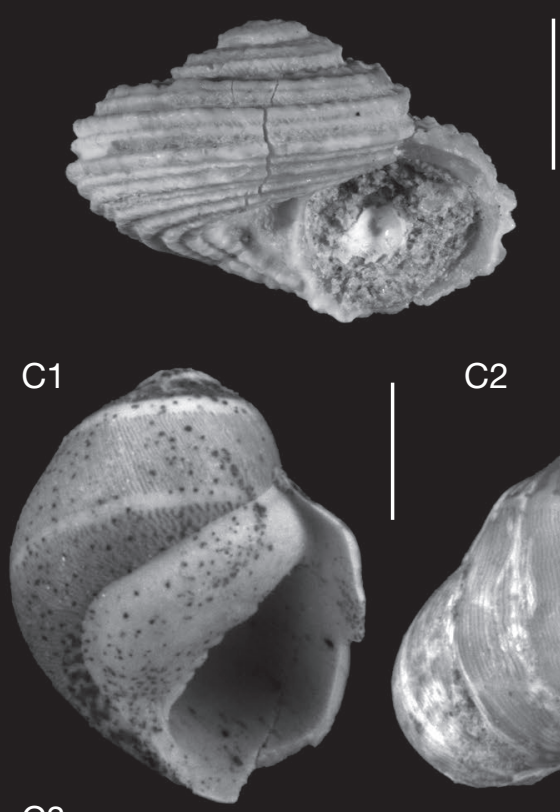

C2
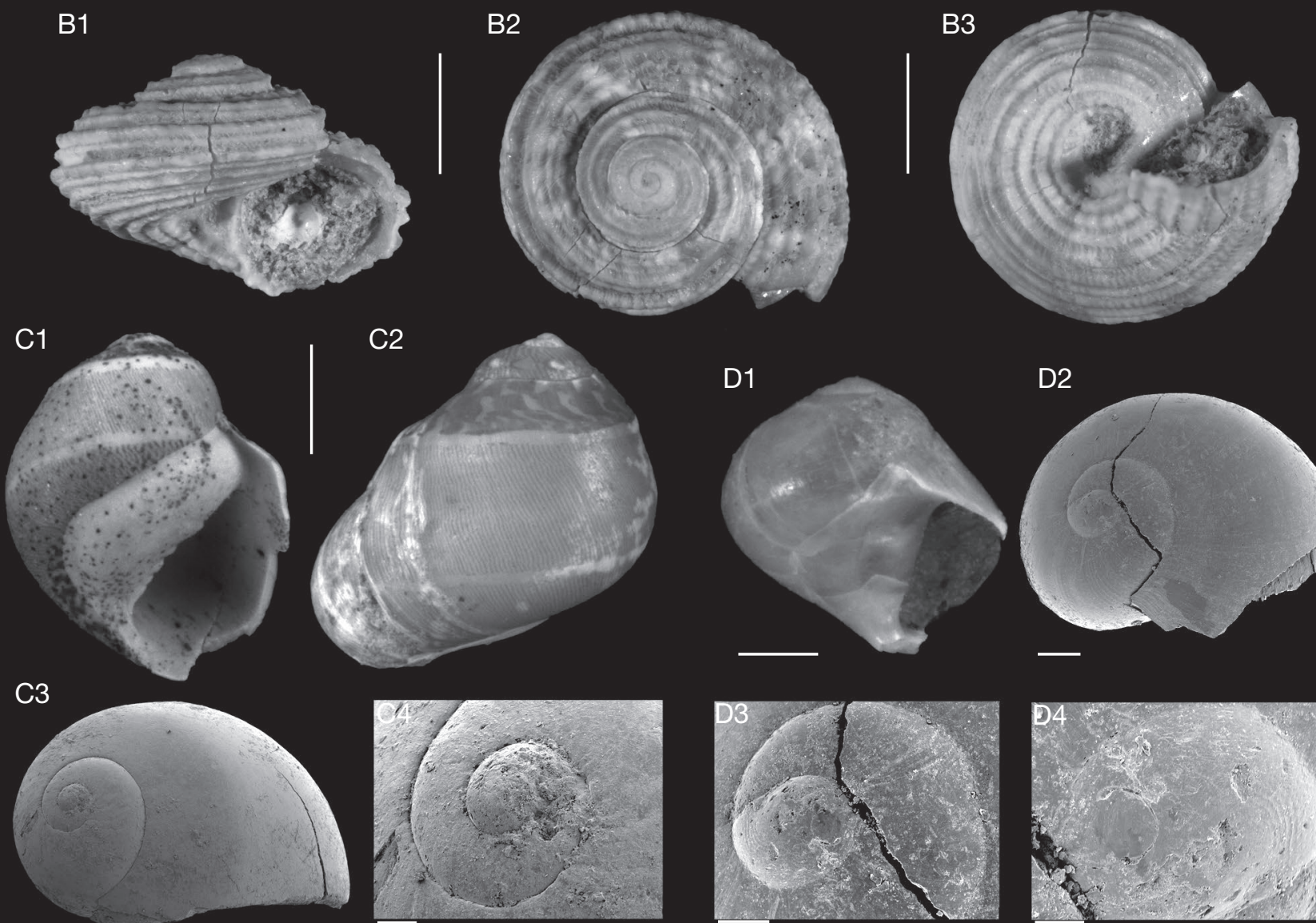

D2

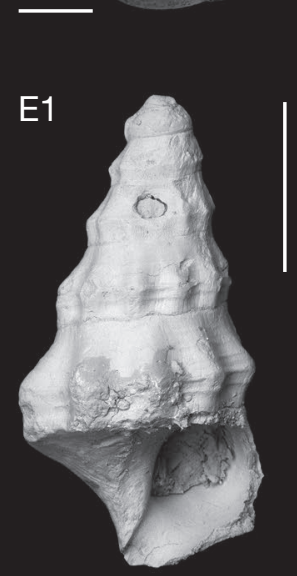

E2

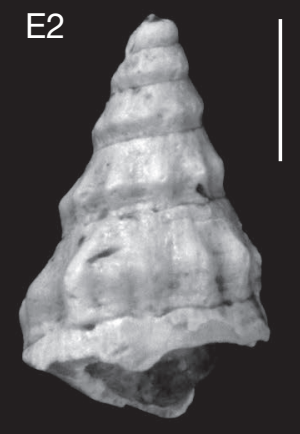

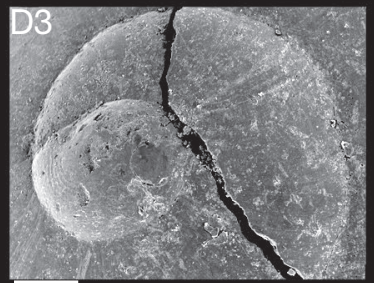
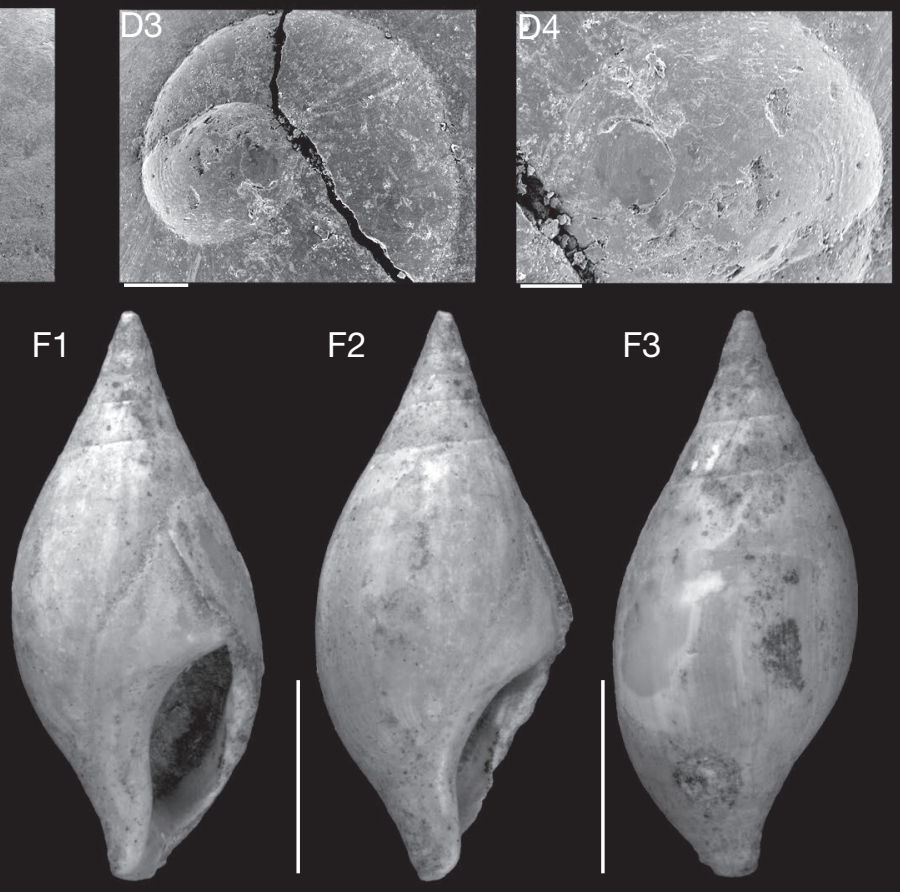

FIG. 3. - A1-A4, Paroxystele orientale (Cossmann \& Peyrot, 1917), AMPG(IV) 1506; B1-B3, Homalopoma acaste n. sp., holotype, AMPG(IV) 1512; C1, C2, Vitta picta (Férussac, 1823), AMPG(IV) 1517; C3, AMPG(IV) 1543 (SEM image); C4, AMPG(IV) 1544 protoconch (SEM image); D1-D4, Neritilia neritinoides (Cossmann \& Peyrot, 1917); D1, AMPG(IV) 1517; D2, AMPG(IV) 1541 (SEM image); D3, D4, AMPG(IV) 1541 protoconch close-ups; E1, E2, Plesiotrochus fallax (juv.) (Grateloup,

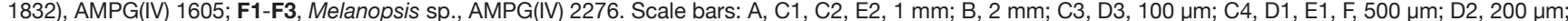
$\mathrm{D} 4,50 \mu \mathrm{m}$. 
Material eXamined. - Sample F1: AMPG(IV) 1543-1547 (five specimens); sample F2: 1548-1573 (26 specimens); sample F3: AMPG(IV) 1574, 1575 (two specimens); sample F7: AMPG(IV) 1576-1593 (18 specimens); sample F8: AMPG(IV) 1594-1595 (two specimens).

Dimensions. - Maximal height $6 \mathrm{~mm}$. Operculum: maximum height $1.67 \mathrm{~mm}$.

Distribution. - Oligocene. NE Atlantic: France (Cossmann \& Peyrot 1917; Lozouet et al. 2001); Western Tethys-Eastern Proto-Mediterranean Sea: Greece, Iran (Harzhauser 2004), Italy (Esu \& Girotti 2010); Paratethys: Austria, Slovakia, Hungary, Germany (Landau et al. 2013).

Early Miocene. NE Atlantic: France (Cossmann \& Peyrot 1917; Lozouet et al. 2001); Proto-Mediterranean Sea: Italy; Greece (Harzhauser \& Kowalke 2001).

Middle Miocene. NE Atlantic: France (Cossmann \& Peyrot 1917; Lozouet et al. 2001); Proto-Mediterranean Sea: Greece (Harzhauser \& Kowalke 2001), Turkey (İslamoğlu 2008); Paratethys: Austria (Schaffer 1912; Harzhauser \& Mandic 2001).

Middle Miocene. NE Atlantic: France (Cossmann \& Peyrot 1917); Proto-Mediterranean Sea: Turkey (Landau et al. 2013); Paratethys: Austria (Hörnes 1856), Ukraine (Bałuk 1975), Hungary (Strausz 1966), Slovakia, Bulgaria, Bosnia (Landau et al. 2013).

\section{REMARKS}

A long list of synonymy is provided in Landau et al. (2013); it includes a list of subspecies and forms that have been published due to the wide morphological range, the resemblance to other Neritidae and the variation of the colour patterns. These colour patterns are usually well preserved even in fragmented specimens and vary from thin zigzag patterns on the entire shell to rather uniformly coloured shells with white flammulae. Two light spiral bands may occur, separating the axial patterns.

Opercula were recovered only when still attached to the shell, therefore only the external side is observable.

The morphology of the shell is somewhat variable and larger specimens may be shouldered. Apertural dentition does not alter with ontogeny; the colour pattern is also present since early ontogenetic stages.

Vitta picta is an indicator of brackish or marine littoral environments (Esu \& Girotti 2010), in the Oligocene it is abundant in the 'Polymesoda-Tympanotonos' and 'Tympanotonos-Pirenella' assemblages as defined by Báldi (1973) (İslamoğlu 2008).

\section{Genus Smaragdia Issel, 1869}

TYPE SPECIES. - Nerita viridis Linnaeus, 1758; subsequent designation by Kobelt (1879). Recent, Mediterranean, Caribbean.

\section{Smaragdia merignacensis (Cossmann \& Peyrot, 1917)}

Neritina (Smaragdia) merignacensis Cossmann \& Peyrot, 1917: 58, pl. 8, figs 21-24.

Material eXamined. - Sample F10: AMPG(IV) 1596-1599 (four specimens [one juvenile]); sample F11: AMPG(IV) 1600, 1601 (two specimens).

Dimensions. - Maximum diameter: $3 \mathrm{~mm}$ (incomplete); maximum height: $2.85 \mathrm{~mm}$ (incomplete).
Distribution. - Early Miocene. Aquitanian. NE Atlantic: France (Cossmann \& Peyrot 1917; Lozouet \& Londeix 2014a [supplementary material CD-Rom]); Proto-Mediterranean Sea: Greece (this paper); Burdigalian. NE Atlantic: France (Cossmann \& Peyrot 1917).

\section{DESCRIPTION}

Shell small, convex, with weakly incised suture; aperture wide; columellar area smooth in juveniles and with small denticles in adult shells. Sculpture consists only of inconspicuous growth lines. Colour pattern consists of wavy opisthocline lines interrupted by two white spiral bands.

\section{REMARKS}

The specimens from Felli seem to be conspecific with $S$. merignacensis with which it agrees in colour pattern and morphology. The colour pattern is somewhat variable ranging from thinner to broader axial lines of the same shape. Juveniles have a relatively simpler pattern with lines that appear at the adapical suture that are always thinner than in adult ones. This species was reported by Cossmann \& Peyrot (1917) from the Aquitanian and Burdigalian of the Aquitaine Basin (France), and although it is not reported from other European locations, the description and illustration fit with the specimens described herein. The largest specimens of the present material are incomplete, but largest fragments suggest a similar size to the French specimens (about $6 \mathrm{~mm}$ maximum height).

Smaragdia species are extremely scarce in Miocene fossiliferous localities throughout Europe. Smaragdia expansa (Reuss in Hörnes, 1856), from the middle Miocene of the Paratethys and north-eastern Atlantic, differs in having a much larger aperture, finer denticles on the columellar area and a more shouldered last whorl.

Recent Smaragdia species have been reported to feed selectively on seagrass tissue (Rueda \& Salas 2007) and they are always associated with seagrasses (Zuschin et al. 2009; Reich et al. 2014). Therefore, the presence of Smaragdia in Felli suggests the presence of seagrass environments.

\section{Subclass CAENOGASTROPODA Cox, 1960 \\ Superfamily CAMPANILOIDEA Douvillé, 1904 \\ Family Plesiotrochidae Houbrick, 1990}

\section{Genus Plesiotrochus Fischer, 1878}

TYPE SPECIES. - Plesiotrochus souverbianus Fischer, 1878, by monotypy. Recent, Indo-West Pacific.

\section{Plesiotrochus fallax (Grateloup, 1832)}

$$
\text { (Fig. 3E1, E2) }
$$

Cerithium fallax Grateloup, 1832: nos 263, 265. — d'Orbigny 1852: nos 1478, 1480.

Hemicerithium fallax - Cossmann \& Peyrot 1922: no. 579, figs 78$83,89$.

Plesiotrochus fallax - Lozouet et al. 2001: 21, pl. 10, figs 1-3. 
MATERIal EXAMINED. — Sample F10: AMPG(IV) 1602-1604 (three specimens); sample F11: AMPG(IV) 1605, 1606 (two specimens).

Dimensions. - Maximum height: $2.15 \mathrm{~mm}$ (incomplete).

Distribution. - Early Miocene. NE Atlantic: France (Aquitaine Basin) (Grateloup 1832; Cossmann \& Peyrot 1922; Lozouet et al. 2001); Proto-Mediterranean Sea: Greece (this paper).

\section{REMARKS}

Until now, Plesiotrochus fallax had only been recordedin the Aquitanian of the Aquitaine Basin in France, where is somewhat variable (as shown by Lozouet et al. (2001)). The present specimens are mostly similar to figures $3 \mathrm{a}$ and 3 b of Lozouet et al. (2001), since the spiral sculpture is inconspicuous, the shell is almost smooth, and the axial varices are relatively rounded. The aperture is broken in all available specimens.

The family Plesiotrochidae was transferred to the superfamily Campaniloidea by Healy (1993) based on recent species.

Modern representatives of the family feed on algae and live in coarse sediments, on reef slopes, sometimes between coral patches and sand with seagrasses (Janssen et al. 2011)

\section{Superfamily CERTITHIOIDEA J. Fleming, 1822} Family CERITHIIDAE Fleming, 1822

\section{Genus Bittium Gray, 1847}

TYPE SPECIES. - Strombiformis reticulatum da Costa, 1778 (= Bittium reticulatum (da Costa, 1778)), subsequent designation by Gray (1847). Recent, Europe.

\section{Bittium larrieyense Vignal, 1911}

(Fig. 4A1-A3)

Bittium vignali var. larrieyensis Vignal, 1911: 160, pl. 8, fig. 19.

Bittium vignali - Vignal 1911: 158, pl. 8, fig. 18. — Cossmann \& Peyrot 1922: 284, no. 615, pl. 7, figs 31, 32, 47-50.

Bittium reticulatum - Vignal 1911: 157.

Bittium asperulatum - Cossmann \& Peyrot 1922: 288, no. 618, pl. 7, figs 66-69.

Bittium larrieyense - Lozouet et al. 2001: 24, pl. 6, figs 6a-c.

Material eXamined. - Sample F10: AMPG(IV) 1607-1645 (39 specimens); sample F11: AMPG(IV) 1646-1890 (245 specimens); sample F12: AMPG(IV) 1891-2071 (181 specimens).

Dimensions. — Maximum height: $3.80 \mathrm{~mm}$.

Distribution. - Early Miocene. Aquitanian. NE Atlantic in France (Cossmann \& Peyrot 1922; Lozouet et al. 2001) and Greece (this paper). - ? Burdigalian. NE Atlantic in France (Cossmann \& Peyrot 1922).

\section{DESCRIPTION}

Turreted shell, minute, with six slightly convex teleoconch whorls. Protoconch of 225-250 $\mu \mathrm{m}$ in diameter, consisting of 2.5 whorls; first whorl low conical, convex; second whorl with mid-whorl angulation coinciding with weak spiral cord. Two faint spiral threads appear close above the abapical suture. Transition into teleoconch marked by deep sinusigera above angulation. Early teleoconch starts with two prominent spiral cords, a third cord appears on the second teleoconch whorl and a fourth on the fifth; regularly spaced axial ribs form pointed nodes at intersections with spiral cords. Broad varix formed on last (preserved) whorl. Microsculpture consisting of spirally arranged small granules, present on entire teleoconch. Sutures linear, impressed. Sculpture very constant, with a fourth spiral cord always forming between the first (adapical) and the second cords on the fifth whorl. A sixth spiral cord forms on the sixth whorl above the abapical suture; for the largest specimens more cords form with new ones added always above the abapical suture. Base with two additional spiral cords; aperture drop-shaped, siphonal canal short.

\section{REMARKS}

The specimens available are fragmentary; the largest fragment consists of eight teleoconch whorls. The shape can vary in width and whorl height; when present, tubercules are not numerous and not very prominent. Whorls are more convex for wider specimens, with an illusion of deeper sutures due to relatively more prominent sculpture.

This species is the most abundant in all the marine beds of Felli. Previously, it was only known from the Early Miocene of France. Morphologically, the Greek specimens are almost identical to the French type and specimens of collection, thus showing stability in the morphological characters and their variation.

The high variability of this species led to the description of several species and variations by Vignal (1911) and Cossmann $\&$ Peyrot (1922), such as B. vignali Dollfus, 1909, Bittium subclathratum (d'Orbigny, 1852) and Bittium asperulum Cossmann $\&$ Peyrot, 1922. As discussed by Lozouet et al. (2001) these taxa seem to represent only morphotypes of $B$. larrieyense.

Family BATILLARIIDAE Thiele, 1929

Genus Granulolabium Cossmann, 1889

TYPE SPECIES. - Cerithium plicatum Bruguière, 1792; by original designation. Early Miocene, France.

\section{Granulolabium plicatum (Bruguière, 1792)} (Fig. 4B1-B3)

Cerithium plicatum Bruguière, 1792: 488. - Hörnes 1856: 400, pl. 42 , fig. 6.

Granulolabium plicatum - Sacco 1895a, div. var.: 58, pl. 3, fig. 45. Lozouet 1986: 171, fig. 2 a-d; 2001: 28, pl. 8., figs 1a-b, 2a-c, 3a c. Harzhauser \& Kowalke 2001: 27, pl. 8, figs 1-3. - Harzhauser 2002: 73, pl. 1, fig. 17-20; 2004: 120, pl. 5, figs 1-4. — İslamoğlu 2008: 266, fig. 6-P. — Esu \& Girotti 2010: 159, pl. 5, figs 10-13. Moths et al. 2010: 32, pl.10, fig. 6, pl. 34, fig. 8. - Lozouet \& Maestrati 2012: 278, figs 180/4-6. - Cluzaud et al. 2014: 226, fig. 171I. - Kovács \& Vicián 2016: 247, pl. 1, fig. 5. 
Cerithium (Granulolabium) plicatum - Schaffer 1912, div. var.: 151, pl. 51, fig. 36-40.

Pirenella plicata-Cossmann \& Peyrot 1921: 267, pl. 5, fig. 99-101, pl. 6, fig. 42-44. - Báldi 1973: 259, pl. 29, fig. 3.

Material eXAmined. - Sample F1: AMPG(IV) 2072-2088 (17 specimens); sample F2: 2089-2138 (50 specimens); sample F3: AMPG(IV) 2139-2166 (28 specimens); sample F7: AMPG(IV) 2167-2226 (60 specimens); sampleF8: AMPG(IV) 2227-2236 (ten specimens); sample F10: AMPG(IV) 2237-2238 (two specimens).

Dimensions. - Maximum height: $35.0 \mathrm{~mm}$.

Distribution. - Oligocene. NE Atlantic, Paratethys, North Sea Basin (Harzhauser 2004); Western Tethys-Proto-Mediterranean Sea: Greece, Turkey (Harzhauser 2004; İslamoğlu 2008).

Early Miocene. NE Atlantic (Lozouet et al. 2001); Proto-Mediterranean Sea: Greece, Turkey (Harzhauser 2004); Paratethys (Schaffer 1912; Mandic et al. 2004); North Sea Basin (Harzhauser 2002; Harzhauser 2004; Büyükmeriç 2017).

\section{REMARKS}

Granulolabium plicatum has been discussed in depth and compared to similar species by Lozouet (1986) in an effort to clarify the differences between various potamidid and batillariid species. In Lozouet et al. (2001), an extensive list of the French literature is presented with the many different names attributed to $G$. plicatum, thus noting the confusion of the authors due to the morphological variability of the species.

The specimens from Felli show some residual colouration patterns that consists of darker and lighter spiral lines that coincide with the ornamentation (the spiral threads are darker and give a brighter colour under UV light).

Granulolabium species are able to withstand variations in salinity and they are known to characterize lagoonal or littoral environments (Latal et al. 2006; Esu \& Girotti 2010). In the Paratethys (Korneuburg Basin, Austria) the GranulolabiumAgapilia biofacies represents slightly energetic conditions of an outer tidal flat (Zuschin et al. 2014).

\section{Family LiTIOPIDAE Gray, 1847}

\section{Genus Gibborissoia Sacco, 1895}

Type SPeCIES. - Bulimus costellatus Grateloup, 1828 (younger subjective synonym of Gibborissoia prevostina (Basterot, 1825)), by original designation. Early Miocene, France.

\section{Gibborissoia varicosa (Basterot, 1825)}

(Fig. 4C1-C3)

Rissoa varicosa de Basterot, 1825: 37, pl. 1, fig. 2.

Gibborissoia varicosa - Landau et al. 2013: 49, pl. 4, fig. 9 (cum syn.).

Gibborissoia varicosa - Harzhauser et al. 2018: 155, fig. 10/N.

Material EXAMINED. - Sample F11: AMPG(IV) 2239-2250 (12 specimens); sample F12: AMPG(IV) 2251-2268 (18 specimens).

Dimensions. - Maximum height: $1.40 \mathrm{~mm}$.
Distribution. — Early Miocene. NE Atlantic: France (Cossmann \& Peyrot 1917; Cossmann 1921; Lozouet et al. 2001); Proto-Mediterranean Sea: Italy (Sacco 1895b) (Burdigalian).

Middle Miocene. Proto-Mediterranean Sea: Turkey (Landau et al. 2013); Paratethys: Austria (Hörnes 1856), Bulgaria (Zilch 1934), Hungary (Strausz 1966), Poland (Bałuk 1975).

\section{REMARKS}

Gibborissoia varicosa displays a large morphological variability, which has led to the description of several varieties. It can range from smooth to varicated and from moderately to strongly elongate with a large last whorl. In the Greek material, the shells are all smooth and elongated, often with a larger last whorl. They are more similar in shape to Serravallian representatives of the species from Turkey (Landau et al. 2013) than with the specimens from the Aquitanian stratotype as illustrated in Lozouet et al. (2001). The Paratethyan subspecies Alaba costellata anomala (Eichwald, 1850), as illustrated in Bałuk (1975), is based on minor morphological features that do not suffice for such a separation, therefore was placed in synonymy with $G$. varicosa by Landau et al. (2013).

Family Melanopsidae H. Adams \& A. Adams, 1854

$$
\text { Genus Melanopsis Férussac, } 1807
$$

TYPE SPECIES. - Melania costata Olivier, 1804, subsequent designation by Gray (1847). Recent, Europe.

\section{Melanopsis sp.}

(Fig. 3F1-F3)

Material EXAMINED. - Sample F2: AMPG(IV) 2269-2275 (seven specimens); sample F7: AMPG(IV) 2276-2279 (four specimens); sample F10: AMPG(IV) 2280 (one specimen).

Dimensions. — Maximum height: $18.0 \mathrm{~mm}$ (incomplete).

Distribution. — Early Miocene. Proto-Mediterranean Sea: Greece (this paper).

\section{DESCRIPTION}

Elongated fusiform shell with acute apical angle and completely flat whorls. Indistinct sutures; shoulder may be present in some specimens. Aperture ovate elongated with slightly elongated siphonal canal; outer lip not preserved; distinct callus. Very weak sculpture consisting of thin sigmoidal growth lines. Residual colour pattern poorly preserved consisting of thin sigmoidal axial lines of approximately equal width.

\section{REMARKS}

A single species of Melanopsis was found in Felli, including a broken juvenile specimen. The specimens seem to represent an undescribed species, but the available material is not sufficient to formally describe it. All specimens are broken and the apical part is always missing. This species might already have been discussed from other Oligocene and lower Miocene sections in the Mesohellenic Basin as 


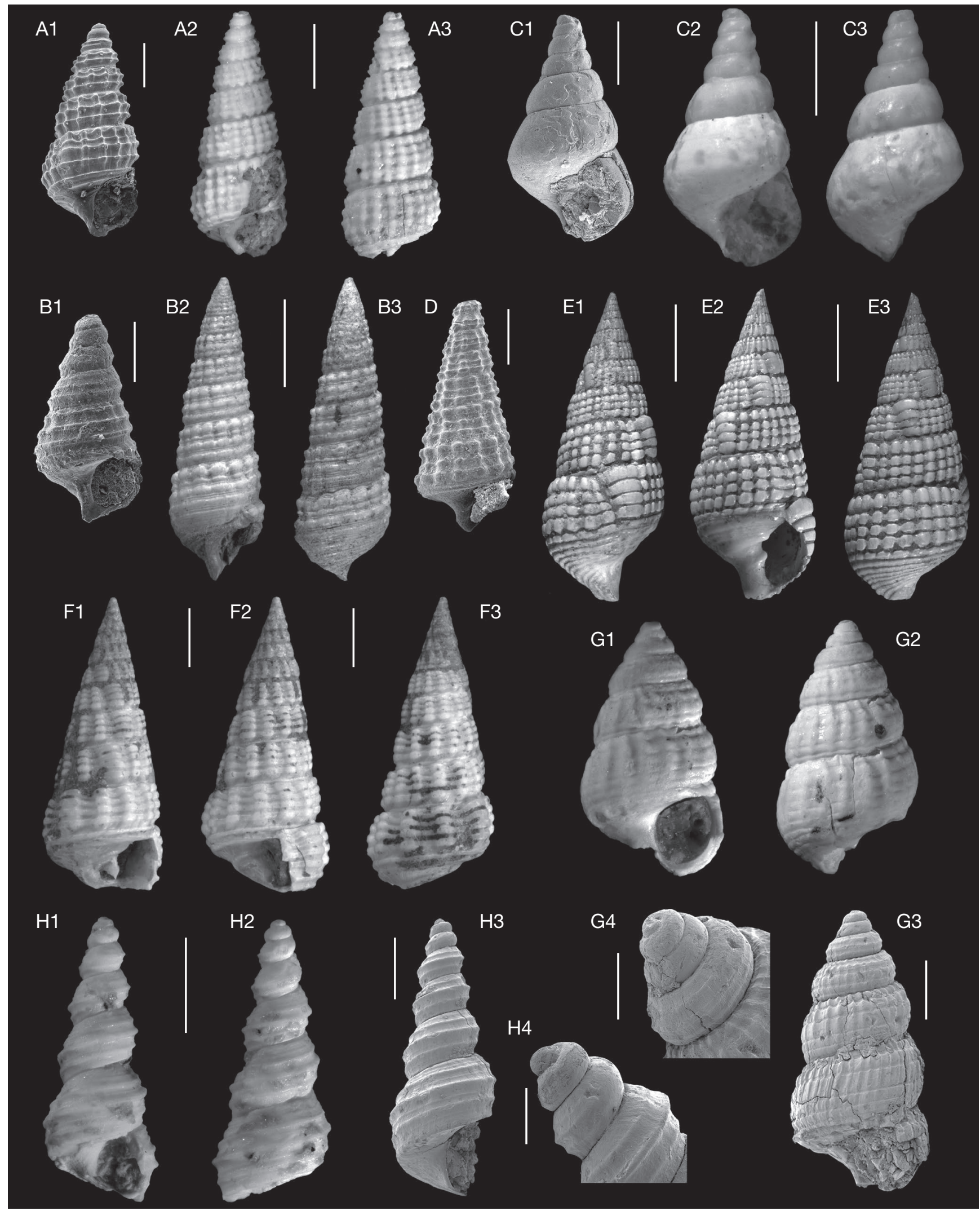

FIG. 4. - A1-A3, Bittium larrieyense Vignal, 1911: A1, AMPG(IV) 1891 (SEM image); A2, A3, AMPG(IV) 1646; B1-B3, Granulolabium plicatum (Bruguière, 1792): B1, AMPG(IV) 2089 (SEM image); B2, B3, AMPG(IV) 2167; C1-C3, Gibborissoia varicosa (de Basterot, 1825): C1, AMPG(IV) 2239 (SEM image); C2, C3, AMPG(IV) 2240; D, Mesohalina margaritacea (Brocchi, 1814), AMPG(IV) 2294 (SEM image); E1-E3, Terebralia lignitarum (Eichwald, 1830), AMPG(IV) 2304; F1-F3, Terebralia subcorrugata d'Orbigny, 1852, AMPG(IV) 2306; G1-G4, Finella perpusilla (Grateloup, 1827): G1, G2, AMPG(IV) 2308; G3, AMPG(IV) 2309 (SEM image); G4, AMPG(IV) 2309, protoconch (SEM image); H1-H4, Turritella turris de Basterot, 1825: H1, H2, AMPG(IV) 2404; H3, AMPG(IV) 2405 (SEM image); H4, AMPG(IV) 2405, protoconch

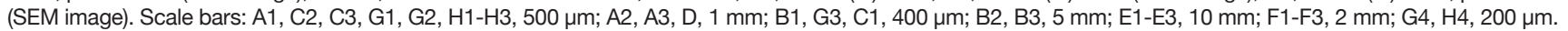


Melanopsis impressa Kraus, 1852 by Harzhauser (2004) and Harzhauser \& Kowalke (2001). Due to the poor preservation of these specimens a comparison with the specimens from Felli remains difficult. In any case, it is unlikely that the Greek records represent Melanopsis impressa, which is a species from the early Miocene of southern Germany (see also discussion in Harzhauser et al. 2016) on Melanopsis hantkeni Hofmann, 1870). A separation of the species from Felli from Melanopsis hantkeni as described by Harzhauser et al. (2016) from the Rupelian of the Thrace Basin is based on its colour pattern of blotches forming a vague zig-zag pattern.

Oligocene and early Miocene Melanopsis species are frequently found in brackish deposits but are assumed to have favoured freshwater envieronments (Neubauer $e$ t al. 2016). In the Serravallian of Turkey, it is still found in brackish deposits (Landau et al. 2013). In the Pliocene and the Lower Pleistocene of Greece, it is found in brackish deposits with freshwater input (Georgiades-Dikaioulia et al. 2002; Moissette et al. 2016). Here, the presence of Melanopsis is considered to be an indicator of freshwater influx, which is in agreement with the preservation of the specimens.

Family PotAmididae H. Adams \& A. Adams, 1854

Genus Mesohalina Wittibschlager, 1983

TYPE SPECIES. - Murex margaritaceus Brocchi, 1814; by original designation. Late Rupelian, Germany.

\section{Mesohalina margaritacea (Brocchi, 1814)}

(Fig. 4D)

Murex margaritaceus Brocchi, 1814: 447, pl. 9, fig. 24.

Cerithium (Tympanotomus) margaritaceum - Schaffer 1912: 154, pl. 52, figs 1,2 .

Tympanotonos margaritaceus - Cossmann \& Peyrot 1921: 248, pl. 6, fig. 64. - Báldi 1973: 260, pl. 29, figs 1, 2.

Potamides margaritaceus - Cluzaud et al. 2014: 226, fig. 171I.

Mesohalina margaritacea - Harzhauser et al. 2016: 28, figs 11-13 (cum syn.).

Material EXAMINED. - Sample F1: AMPG(IV) 2281-2283 (three specimens); sample F2: AMPG(IV) 2284-2293 (ten specimens); sample F7: AMPG(IV) 2294-2303 (ten specimens).

Dimensions. - Maximum height: $28.0 \mathrm{~mm}$ (incomplete).

Distribution. - Oligocene. NE Atlantic: France (Lozouet et al. 2001); Proto-Mediterranean Sea: Italy (Esu \& Girotti 2010), Greece (Harzhauser 2004), Turkey (İslamoğlu 2008); Paratethys (Reid et al. 2008; Harzhauser et al. 2016).

Early Miocene. Aquitanian-mid-Burdigalian. NE Atlantic: France (Aquitaine Basin) (Cossmann \& Peyrot 1921; Lozouet et al. 2001); Proto-Mediterranean Sea: Greece (Harzhauser \& Kowalke 2001; Harzhauser 2004), Turkey (Büyükmeriç 2017); Paratethys: Austria, Slovakia, Slovenia (Harzhauser et al. 2016).
REMARKS

A detailed description of the species is given in Harzhauser et al. (2016) and a long list of synonyms is provided by Esu \& Girotti (2010). In addition to these descriptions, we observe a fine microstructure between the spiral cords that consists of very subtle fine threads. The specimens are not well enough preserved in order to count the threads, but there seem to be at least three. In Felli, the first (adapical) row of beads becomes more prominent and on some of the largest specimens it develops into a thick spinous keel on the last one or two whorls. The varices described in the largest specimens of the Oligocene (Rupelian) of the Thrace Basin (Harzhauser et al. 2016) are not present in the Felli material. Compared to the Oligocene samples from Greece (Harzhauser 2004), the ornamentation is less prominent and the flaring outer lip is less developed. The morphology of the specimens from the Aquitanian stratotype (Lozouet et al. 2001) is the most similar to the specimens from Felli.

The enormous shell variability seen in this species has led to the erection of a noumerous subspecific and varietal names (see Esu \& Girotti 2010). Although M. margaritacea was placed in the Extant West African genus Tympanotonos Schumacher, 1817 by many authors, its separation from that genus and its placement in Mesohalina was clarified by Wittibschlager (1983), Kadolsky (1995) and Harzhauser et al. (2016) based on conchological features of the protoconch and early teleoconch. Reid et al. (2008) treat the genus Mesohalina as a synonym or subgenus of the genus Potamides Brongniart, 1810. Nevertheless, we consider Mesohalina to be clearly separated from Potamides based on the much broader shell, the angular aperture and the different mode of formation of the sculpture of the early whorls (see Kadolsky 1995).

\section{Genus Terebralia Swainson, 1840}

TYPE SPECIES. - Strombus palustris Linnaeus, 1758; subsequent designation by Sacco (1895b). Recent, Indo-West Pacific.

Terebralia lignitarum (Eichwald, 1830)

(Fig. 4E1-E3)

Cerithium lignitarum Eichwald, 1830: 224.

Terebralia lignitarum - Landau et al. 2013 (cum syn.): 51, pl. 4, fig. 11. Material EXAMINED. — AMPG(IV) 2304-2305 (two specimens).

Dimensions. - Maximum height: $91.0 \mathrm{~mm}$.

Distribution. - Late Oligocene. Proto-Mediterranean Sea: Turkey (İslamoğlu 2008), Greece (Harzhauser 2004); Paratethys: Hungary (Janssen 1984); east-African-Arabian province: Oman (Harzhauser 2007).

Early Miocene. NE Atlantic: France (Cossmann \& Peyrot 1922; Lozouet et al. 2001); Proto-Mediterranean Sea: Italy (Sacco 1895b), Greece (Harzhauser \& Kowalke 2001), Turkey (Landau et al. 2013); Paratethys: Austria (Harzhauser \& Kowalke 2001).

Middle Miocene. NE Atlantic: France (Cossmann \& Peyrot 1922; Glibert 1949); Paratethys: Austria (Hörnes 1856), Poland (Bałuk 1975), Hungary (Strausz 1966); Eastern Paratethys (Landau et al. 2013). 
Late Miocene. NE Atlantic: Portugal (Landau et al. 2013); eastern Mediterranean Sea: Italy (Sacco 1895b), Greece (Dermitzakis 1972).

\section{REMARKS}

In the studied material, a few specimens are present that could be juvenile specimens of T. lignitarum. The species is well known from the Oligocene and the Miocene of the Paratethys, the Western Tethys - Proto-Mediterranean and the North Atlantic Ocean, and is commonly found in lagoonal or brackish environments. It is also present in the Middle Miocene (Serravallian) of Turkey (Landau et al. 2013).

The morphological variation of the species has led to the creation of some varieties, mainly by Sacco (1888, 1895b). The shape of the shell can be more or less elongated, and the sculpture can form some axial tubercules. Landau et al. (2013) also provide a full list of synonyms and a discussion on the nomenclature and the morphological variations.

Modern representatives of Terebralia are found in mangroves or mudflats (Reid et al. 2008). In the fossil record T. lignitarum is found in brackish deposits (Landau et al. 2013), mudflats (Latal et al. 2006) and mangroves (Harzhauser 2007).

\section{Terebralia subcorrugata d'Orbigny, 1852}

(Fig. 4F1-F3)

Cerithium corrugatum Basterot, 1825: 54.

Cerithium subcorrugatum - d'Orbigny 1852: 80.

Terebralia subcorrugata - Cossmann \& Peyrot 1922: 257, pl. 5, figs 93-98, pl.6, figs 2, 8, 9. - Lozouet et al. 2001: 26, pl. 8, figs 6a, b, 7a, b, pl. 10, fig. 10. — Esu \& Girotti 2010: 158, pl. 6, figs 4-7. — Cluzaud et al. 2014: 226, fig. 171D.

Terebralia cf. subcorrugata - Harzhauser 2004: 119, pl. 6, figs 5, 8.

Material eXamined. — Sample F7: AMPG(IV) 2306, 2307 (two specimens).

Dimensions. — Maximum height: $10.0 \mathrm{~mm}$.

Distribution. - Oligocene. NE Atlantic: France (Cossmann \& Peyrot 1922; Lozouet 1986), Iran as T. cf. subcorrugata (Harzhauser 2004); Western Tethys: Italy (Esu \& Girotti 2010).

Early Miocene. NE Atlantic: France (Lozouet et al. 2001), ProtoMediterranean Sea: Turkey (İslamoğlu \& Taner 2003), Greece (this paper).

\section{DESCRIPTION}

Turreted solid shell with flat whorls, with deep sutures. Sculpture consisting of four distinct spiral cords spaced by deep grooves of equal width. A fifth inconspicuous spiral thread appears above the adapical suture. Wide-spaced prominent axial ribs may form small varices; a well-developed varix is present on the last whorl; base of the last whorl bearing four granulated spiral threads. Aperture ovate with prominent columellar fold; siphonal canal thin and short.

\section{REMARKS}

This species is reported here for the first time from Greece. The two specimens of T. subcorrugata found in Felli show the features of both juveniles and adult specimens, although the protoconch is missing. Esu \& Girotti (2010) recorded this species in the Oligocene of southern Italy where few specimens were available, illustrating low morphological variation. The Felli material is insufficient to deduce any variability, but as agree in shell characters with the Italian specimens, differingin having weaker and less spiny axial ribs. Terebralia cf. subcorrugata from the Oligocene of Iran (Harzhauser 2004) has more convex whorls but displays the same axial sculpture. It is easily distinguished from Granulolabium plicatum by the more prominent spiral sculpture. The specimens from Felli are morphologically almost identical to the French representatives from the Early Miocene of the Aquitaine Basin housed at the historical Cossmann collection of the Muséum national d'Histoire naturelle (Paris).

Recent representatives of Terebralia are limited to the IndoPacific Ocean, and are associated with mangrove environments (Plaziat 1995). In the Oligocene of Iran, T. cf. subcorrugata has been found with Granulolabium plicatum, Vitta cf. picta and Cerithiidae (Harzhauser 2004).

Family SCALIOLIDAE Jousseaume, 1912

Genus Finella A. Adams, 1860

TyPe SPECIES. - Finella pupoides A. Adams, 1860, by monotypy. Recent, Indo-Pacific.

Finella perpusilla (Grateloup, 1827) n. comb. (Fig. 4G1-G4)

Rissoa perpusilla Grateloup, 1827: 133, no. 103.

Sandbergeria perpusilla - Landau et al. 2013: 48, pl. 54, figs 11-14 (cum. syn.).

Material eXAmined. — Sample F11: AMPG(IV) 2308-2383 (76 specimens); sample F12: AMPG(IV) 2384-2399 (16 specimens).

Dimensions. - Maximum height: $2.10 \mathrm{~mm}$.

Distribution. — Early Miocene. NE Atlantic: France (Cossmann \& Peyrot 1922); Proto-Mediterranean Sea: Italy (Sacco 1895b), Greece (this paper).

Middle Miocene. NE Atlantic: France (Cossmann \& Peyrot 1922; Glibert 1949); Proto-Mediterranean Sea: Turkey (Landau et al. 2013); Paratethys: Austria (Hörnes 1856), Poland (Bałuk 1975), Hungary (Strausz 1966), Romania (Zilch 1934).

\section{REMARKS}

The species is placed here in the genus Finella (A. Adams, $1860 \mathrm{~b}$ ) since it bears more common characters with the type of this genus than with Sandbergeria Bosquet, 1861 (type species S. cancellata Nyst, 1836, Early Oligocene of Belgium). These include a planktotrophic protoconch, a more conical shape, a short and indistinct siphonal canal, a straight columellar with broad callus, which forms a narrow columellar lip (Marquet et al. 2008). Finella perpusilla has orthocline growth lines and fine ribs, as well as a very characteristic sculpture with regularly spaced inconspicuous spiral furrows (clearly visible 
in SEM pictures), absent on the middle part of the whorl. The shape of the shell can vary from more elongated with low whorl expansion, to less elongated and more conical with slightly wider whorls. The Greek specimens are very similar to the Serravallian specimens from Turkey (Landau et al. 2013) concerning variabilty of morphology and sculpture.

The species was widespread in the Paratethys during the Miocene (Zuschin et al. 2004, 2005, 2006) where it was an important component of the assemblages, but is absent from the NE Atlantic and North Sea Basin. Modern representatives of the genus are detritus feeders that live on mobile bottoms, sometimes associated with corals or seagrass (R. Janssen et al. 2011). Finella bruchae was also found within a seagrass-associated gastropod fauna in the Early Miocene of India (Harzhauser 2014).

\section{Family TURRITELLIDAE Lovén, 1847}

\section{REMARK}

In the present work, and due to the preservation of the specimens, we place the species in the genus Turritella (s.l.).

\section{Genus Turritella (s.l.) Lamarck, 1799}

TYPE SPECIES. - Turbo terebra Linnaeus, 1758, by monotypy. Recent, Indo-West Pacific.

Turritella turris de Basterot, 1825

(Fig. 4H1-H4)

Turritella turris Basterot, 1825: 29, pl. 1, fig. 11. - D'Orbigny 1852: 42, no. 430, 32. - Cossmann \& Peyrot 1922: 39, pl. 1, fig. 25, pl. 11, figs 21-24. — Lozouet et al. 2001: 29, pl. 7, figs 1a-b.

Turritella (Turritella) turris - İslamoğlu 2004: 143, pl. 1, fig. 4.

Material EXAMINED. — Sample F10: AMPG(IV) 2400-2403 (four specimens); sample F11: AMPG(IV) 2404-2422 (19 specimens); sample F12: AMPG(IV) 2423-2434 (12 specimens).

Dimensions. - Maximum height: $11 \mathrm{~mm}$ (incomplete); maximum width: $5 \mathrm{~mm}$.

Distribution. - Early Miocene. Aquitanian. NE Atlantic: France (Cossmann \& Peyrot 1922; Lozouet et al. 2001); Proto-Mediterranean Sea: Greece (this paper). - Burdigalian. NE Atlantic: France (Cossmann \& Peyrot 1922); Proto-Mediterranean Sea: Turkey (İslamoğlu 2004) (Burdigalian).

Late Miocene-Pliocene. Eastern Mediterranean Sea: Greece (Koskeridou 1997).

\section{DESCRIPTION}

Protoconch smooth, $250 \mu \mathrm{m}$ in diameter. Transition to protoconch marked by the beginning of teleoconch sculpture. Teleoconch sculpture consisting of three equidistant spiral cords, with cord two being more prominent. Finer cords develop from whorl four and on, below the adapical suture, between the cords and below cord three. Microsculpture consists of very fine irregularly spaced threads between all cords. Apical angle of about $30^{\circ}$. Aperture missing.

\section{REMARKS}

The specimens are conspecific with Turritella turris of the type-region of the Aquitanian (Aquitaine, France). There is little variation in the convexity of the whorls; most convex whorls bear more prominent sculpture and are more angular. There is also some variation in the microsculpture with the spiral threads also becoming more prominent.

Turritellids are suspension feeders partially borrowed in the sand (Allmon 2011).

Superfamily EPITONIOIDEA Berry, 1910 (1812)

Family EPITONIIDAE Berry, 1910 (1812)

Genus Nodiscala de Boury, 1878

TYPE SPECIES. - Scalaria bicarinata G.B. Sowerby, 1844, by original designation. Recent, Philippines.

Nodiscala cf. rugatina de Boury in Cossmann, 1912

(Fig. 5A1, A2])

cf. Nodiscala rugatina - Cossmann 1912: 85, pl. 5, figs 23-25.

cf. Opalia (Nodiscala) rugatina - Zilch 1934: 228, pl. 10, fig. 72.

Material eXamined. — Sample F11: AMPG(IV) 2335, 2336 (two specimens).

Dimensions. — Maximum height: $3 \mathrm{~mm}$ (incomplete).

Distribution. — Early Miocene. Proto-Mediterranean Sea: Greece (this paper).

\section{DESCRIPTION}

Protoconch missing. Turreted, slender shell of six regularly convex teleoconch whorls; axial sculpture consists of orthocline and closelyspaced relatively prominent rounded axial costae, no varices present. Suture moderately incised; spiral sculpture composed of irregularlyspaced spiral punctuation. Aperture sub-ovate, incomplete.

\section{REMARKS}

The specimens of the present material are reminiscent of Nodiscala rugatina from the middle Miocene of Romania. The syntypes, illustrated by Cossmann (1912) and Zilch (1934), however display slightly angulated whorls and less prominent axial ribs. Therefore, we identify the distinctly older Greek species as Nodiscala cf. rugatina.

The Greek specimens are similar to Nodiscala bezanconi (de Boury, 1893) from the late Oligocene of France as illustrated in Lozouet \& Maestrati (2012), but this species has more convex whorls and deeper sutures. Nodiscala bimonilifera (Boettger, 1902), from the middle Miocene of Romania, differs in its more slender cylindrical outline and in its blunt nodes on the last whorl. The Greek specimens also show some resemblances to Opalia pertusa (Nyst, 1871) from the Miocene of the Netherlands (A.W. Janssen 1984).

Epitoniid species are known to be parasites on corals (Kokshoorn et al. 2007). 
Superfamily TRIPHOROIDEA Gray, 1847

Family TRIPHORIDAE Gray, 1847

Genus Triphora (s.l.) Blainville, 1828

TyPe SPECIES. - Triphora gemmata Blainville, 1828, by monotypy. Recent, Indo-West Pacific.

Triphora (s.l.) sp.

(Fig. 5B1, B2)

Material eXamined. - Sample F10: AMPG(IV) 2437, 2438 (two specimens); sample F11: 2439-2442 (four specimens).

Dimensions. - Maximum height: $2.10 \mathrm{~mm}$ (incomplete).

Distribution. - Early Miocene. Proto-Mediterranean Sea: Greece (this paper).

\section{DESCRIPTION}

Shell minute, turriculate. Protoconch conical of 4.5 whorls. Protoconch II bears two spiral keels and regularly-spaced axial riblets. Four teleoconch whorls preserved. First whorl bears two beaded cords; cord 1 placed below suture; cord 2 above abapical suture. Axial sculpture of smooth, slightly prosocline ribs, weaker than cords, with beads forming at instersections.

\section{REMARKS}

All of the specimens recovered are incomplete. Therefore, the complete sculpture and structure of the teleoconch are not available. There are some similarities with the species recovered in the Serravallian of Turkey (Landau et al. 2013), Triphora (s.l.) sp., for which the third beaded cord appears on the sixth teleoconch whorl.

A slight concavity of the early teleoconch is reminiscent of Obesula sp. (Van Dingenen et al. 2016), but no more characters of the present shell can place it in this genus. The present species also has a similar early teleoconch sculpture to Marshallora adversa (Montagu, 1803) (Marquet 1996), but with a different protoconch structure and with the aperture missing from our specimen, it is impossible to attribute the species to Marshallora (Bouchet, 1985).

\section{Genus Metaxia Monterosato, 1884}

Type species. - Murex metaxa Delle Chiaje, 1828, subsequent designation by Cossmann (1906). Recent, Caribbean.

\section{Metaxia sp.}

(Fig. 5C1-C4)

Material examined. - Sample F11: AMPG(IV) 2443, 2444 (two specimens).

Dimensions. — Maximum height: $1.55 \mathrm{~mm}$ (incomplete).

Distribution. — Early Miocene. Proto-Mediterranean Sea: Greece (this paper).

\section{DESCRIPTION}

Dextrally coiled species of elongate, turriculate shape. High, multispiral protoconch with 4.5 whorls; protoconch I convex with delicate sculpture of zigzag spiral threads; protoconch II with narrow axial riblets; keel slightly below midwhorl increasing in strength towards teleoconch. Teleoconch incomplete, consisting of four convex whorls; apical angle of teleoconch $21^{\circ}$. Sculpture comprising 5 spiral cords: two weak cords in adapical part of whorl, two more prominent median ones of which upper one coincides with periphery; one weak spiral cord at abapical suture.

Spiral cords cover broad axial ribs, forming weak nodular intersections on median spiral cords. Aperture missing.

\section{REMARKS}

The present species has a similar morphology to the type species of the genus, Metaxia metaxa (Delle Chiaje, 1828), has a protoconch of 3.5 whorls and flatter teleoconch whorls. Athother similar species is Metaxia carinapex van der Linden, 1998 from the eastern Atlantic which has a lecithotrophic protoconch of 2.5 whorls and a teleoconch sculpture is less prominent with less broad axial ribs.

Regarding fossil species, sculpture and morphology are reminiscent of Metaxia permacra Lozouet, 1999 from the Late Oligocene of the Aquitaine Basin (France) (Lozouet 1999), which differs mainly in its more slender outline, strongly incised suture and the protoconch, which comprises only 3.5 whorls. Metaxia merignacensis (Cossmann \& Peyrot 1922) from the Early Miocene of the Aquitaine Basin differs in its extremely elongate shell, prominent spiral cords and shorter protoconch of 3.5 whorls. Although Metaxia degrangei sensu Marquet (1996), from the early Miocene of the North Sea Basin is considered a synonym of M. merignacensis by Lozouet et al. (2001), it is morphologically distinct. The common features with the Greek species include a similar teleoconch sculpture and shell shape, but differences in the protoconch with 5.5 whorls with two spiral keels (Marquet 1996) set it as a separate species.

Family Cerithiopsidae H. Adams \& A. Adams, 1854

Genus Dizoniopsis Sacco, 1895

TYPE SPECIES. — Murex tubercularis Montagu, 1803, by monotypy. Recent, Europe.

REMARK

The genus Dizoniopsis Sacco, 1895 is used herein based on teleoconch sculpture that bears two rows of beads, following Bouchet et al. (2010) and Landau et al. (2018).

\section{Dizoniopsis sp.}

(Fig. 5D1-D3)

Material eXAmined. - Sample F11: AMPG(IV) 2445-2447 (three specimens). 
Dimensions. - Maximum height: $3.20 \mathrm{~mm}$.

Distribution. - Early Miocene: Proto-Mediterranean Sea: Greece (this paper).

\section{DESCRIPTION}

Protoconch missing. Early teleoconch whorls are flat; sculpture consists of two equidistant rows of regularly-spaced rounded beads. The abapical row of beads also has a faint spiral cord between beads. Microsculpture consists only of very fine orthocline growth lines. On later whorls the upper row becomes more elongated axially and forms an angle at the suture. A spiral cord is present abapically on the suture. The base has two spiral cords; small columellar fold; aperture missing.

\section{REMARKS}

The morphology of the teleoconch and outline of the present species is similar to Cerithiopsis (s.l.) cf. bilineata (Hoernes, 1848) present in the Serravallian of Turkey (Landau et al. 2013). The protoconch is an important character for species-level identification, as it is missing from the recovered specimens, a precise identification is not possible.

Vatopsis bimonilifera (Sandberger, 1859) from the Oligocene of France (Lozouet \& Maestrati 2012) is very similar to the present specimen; species of Vatopsis all have a spiral as well as an axial sculpture on protoconch whorls.

Cerithiopsis species are feeding on sponges in environments down to $200 \mathrm{~m}$ (Marshall 1978).

Superfamily RissooideA Gray, 1847

Family RissoinidaE Stimpson, 1865

\section{Genus Rissoina d'Orbigny, 1840}

Type species. - Rissoina inca d'Orbigny, 1840, by original designation. Recent, Peru.

Rissoina subconoidea (Grateloup, 1847) (Fig. 5E1, E2)

Rissoa cochlearella var. A subconoidea Grateloup, 1847: 4, figs 17, 18. Rissoina subconoidea - Landau et al. 2013: 75, pl. 6, fig. 9 (cum syn.).

Material examined. - Sample F10: AMPG(IV) 2448-2450 (three specimens).

Dimensions. - Maximum height: $1.85 \mathrm{~mm}$ (incomplete).

Distribution. - Late Oligocene. NE Atlantic: France (Aquitaine Basin) (Cossmann \& Peyrot 1919; Lozouet et al. 2001).

Early Miocene. NE Atlantic: France (Aquitaine Basin) (Cossmann \& Peyrot 1919; Lozouet et al. 2001); Proto-Mediterranean Sea: Greece (Aquitanian, this paper), Italy (Burdigalian, Sacco 1896).

Middle Miocene. NE Atlantic: France (Aquitaine Basin) (Cossmann \& Peyrot 1919); Proto-Mediterranean Sea: Turkey (Landau et al. 2013); Paratethys: Austria (Hörnes 1856), Poland (Bałuk 1975), Hungary (Strausz 1966).

\section{REMARKS}

The species has a characteristic elongated solid shell with slightly opisthocline axial ribs. The subobsolete spiral sculpture of the last whorl mentioned by Landau et al. (2013) is not preserved in our incomplete material.

Lozouet et al. (2001) treated Rissoina podolica Cossmann, 1921 as subjective junior synonym of $R$. subconoidea (Grateloup, 1847), which is followed herein.

During the Early Miocene (Aquitanian and Burdigalian) $R$. subconoidea was relatively widespread in the northeastern Atlantic and the Proto-Mediterranean. According to Ponder (1984), recent Rissoina species take shelter beneath stones and in crevices and feed on foraminifers. Rissoina species live in littoral environments (Tămaș et al. 2013), they are also known from seagrass-associated gastropod communities (Harzhauser 2014).

\section{Genus Zebinella Mörch, 1876}

TyPe SPECIES. - Helix decussata Montagu, 1803, subsequent designation by Von Martens, 1878. Recent, Caribbean.

Zebinella sp.

(Fig. 5F1, F2)

Material eXamined. - Sample F11: AMPG(IV) 2451-2454 (four specimens).

DimENSIONS. - Maximum height: $3.40 \mathrm{~mm}$ (incomplete).

Distribution. - Early Miocene. Proto-Mediterranean Sea: Greece (this paper).

\section{DESCRIPTION}

Shell small, turriculate. Protoconch smooth, incomplete, of at least 2 whorls. Early teleoconch whorls convex, with fine sculpture of slightly opisthocline axial ribs, and a spiral cord approximately at mid-height of the whorl. Teleoconch whorls flat; sculpture consists of the same axial ribs, fine irregularly spaced spiral cords present between ribs. Cords become stronger after the fifth whorl abapically. Sutures fine, linear.

\section{REMARKS}

This Zebinella species is represented only by incomplete specimens. We place it in Zebinella and not Rissoina because of the fine axial sculpture and the elongated shape of the shell. It is reminiscent of Zebinella cf. decussata (Montagu, 1803) from the Serravallian of the Karaman Basin in Turkey (Landau et al. 2013). Both taxa have delicate, flattened, opisthocline axial ribs, but the whorls of the Greek species are more convex.

The protoconch is incomplete in the present material, but seems to be smooth. A weak spiral cord appears on the first three teleoconch whorls teleoconch in the adapical half of the whorl, forming a weak angulation as in Zebinella cf. decussata; some finer spiral threads appear after the fifth teleoconch whorl abapically, which seem to distinguish the present species. 


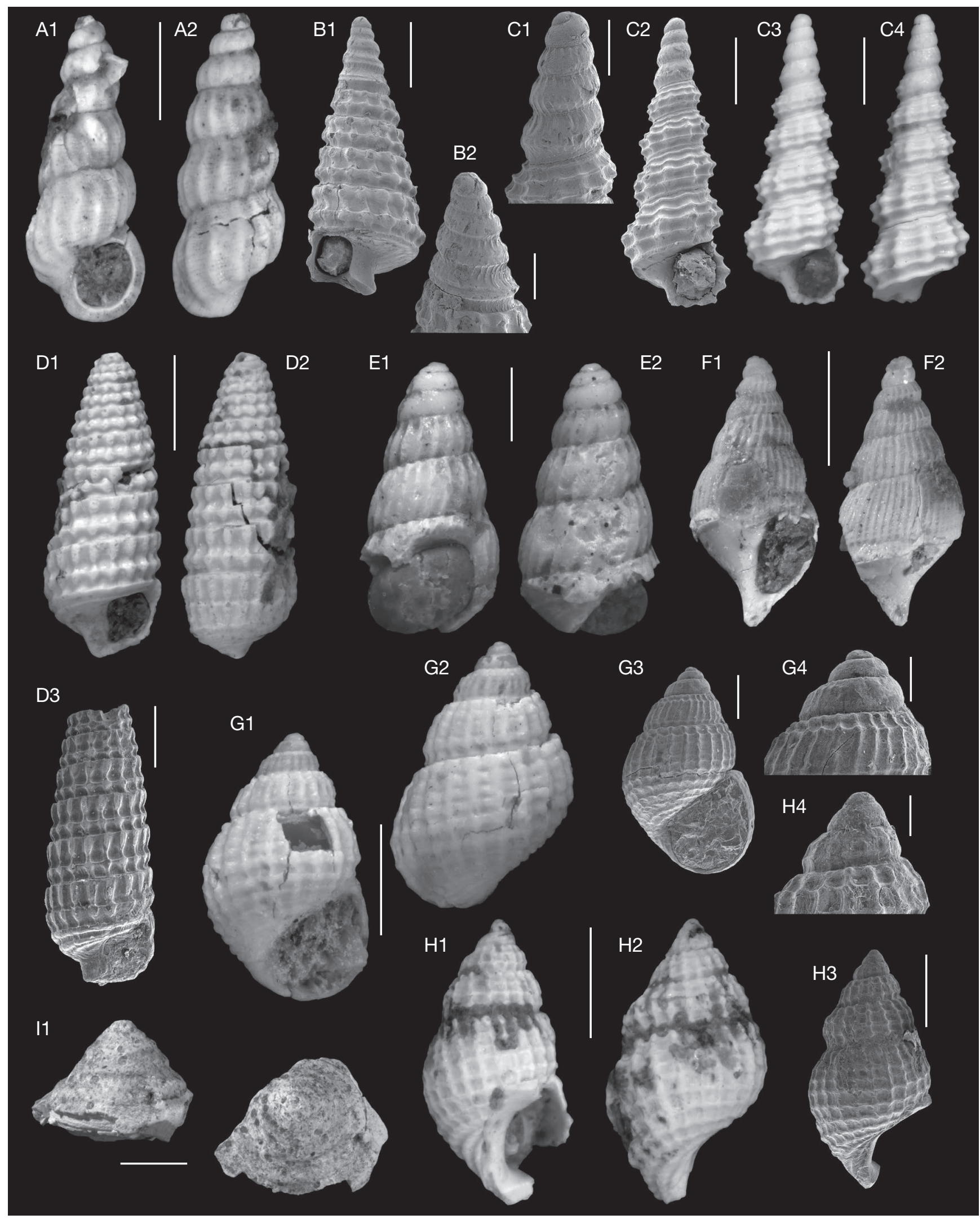

FiG. 5. - A1, A2, Nodiscala cf. rugatina de Boury in Cossmann, 1912: A1, A2, AMPG(IV) 2335; B1, B2, Triphora (s.l.) sp.: B1, AMPG(IV) 2439 (SEM image); B2, AMPG(IV) 2439, protoconch (SEM image); C1-C4, Metaxia sp.: C1, AMPG(IV) 2443, protoconch (SEM image); C2, AMPG(IV) 2443 (SEM image); C3, C4, AMPG(IV) 2443; D1-D3, Dizoniopsis sp.: D1, D2, AMPG(IV) 2445; D3, AMPG(IV) 2446 (SEM image); E1, E2, Rissoina subconoidea (Grateloup, 1847); E1, E2, AMPG(IV) 2448; F1, F2, Zebinella sp., AMPG(IV) 2451; G1-G4, Alvania amphitrite n. sp.: G1, G2, holotype, AMPG(IV) 1503; G3, paratype 2, AMPG(IV) 1505 (SEM image); G4, paratype 2, AMPG(IV) 1505, protoconch (SEM image); H1-H4, Alvania transiens (Sacco, 1895): H1, H2, AMPG(IV) 2455; H3, AMPG(IV) 2456 (SEM image); H4, AMPG(IV) 2456, protoconch (SEM image);

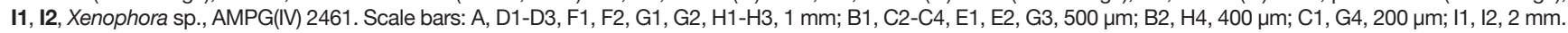


Recent representatives of the genus have been found on reef slopes and in sands between coral patches (Janssen et al. 2011).

\section{Family RISSOIDAE Gray, 1847}

\section{REMARK}

The family Rissoidae is a diverse family of small-sized caenogastropods (Criscione \& Ponder 2012).

\section{Genus Alvania Risso, 1826}

TYPE SPECIES. - Alvania europea Risoo, 1826 (= Alvania cimex (Linnaeus, 1758)), subsequent designation by Nevill (1885). Recent, Europe, Mediterranean Sea.

\section{Alvania amphitrite n. sp.}

(Fig. 5G1-G4)

urn:Isid:zoobank.org:pub:A2760279-BE3E-4730-9688-9AB777F3A357

TyPe MATERIAL. - Holotype: AMPG(IV) 1503, height $2.50 \mathrm{~mm}$. Paratype 1: AMPG(IV) 1504, $2.20 \mathrm{~mm}$. — Paratype 2: AMPG(IV) 1505, height $1.95 \mathrm{~mm}$.

DimENSIONS. - Maximum height: $2.50 \mathrm{~mm}$; maximum width: $1.70 \mathrm{~mm}$.

ETymology. - Named after the Nereid Amphitrite of Greek mythology, wife of Poseidon and protector of marine animals (as noun in apposition).

TYPE LOCALITY. - Felli village section, $40^{\circ} 01^{\prime} 4.55^{\prime \prime} \mathrm{N}, 21^{\circ} 33^{\prime} 34.37^{\prime \prime}$, Mesohellenic Basin, Grevena area, Greece.

TyPE LEVEL. — Pentalofos Formation, Aquitanian, lower Miocene.

DiAGNOSIS. - Shell small; protoconch consisting of about 2.5 whorls. Sculpture reticulated, ad-and abapical spiral cords strengthened, whorls flat, suture deep. Last whorl tall and rounder; aperture wide, teardrop-shaped

Distribution. - Early Miocene. Proto-Mediterranean in Greece (this paper).

\section{DESCRIPTION}

Small, ovoid species; protoconch of 2.5 rounded smooth whorls, measuring $0.29 \mathrm{~mm}$ in height and $0.34 \mathrm{~mm}$ in width. Teleoconch of 3.5-4 flat whorls, last whorl occupies approximately $70 \%$ of total length. Sculpture consisting of 12 axial ribs and 6 spiral cords; second and last spiral cords stronger, middle cords more closely-spaced. Base with 5 spiral cords and faint axial riblets; no umbilicus; aperture wide, tear-drop shaped; outer lip somewhat inflated.

\section{REMARKS}

The protoconch whorls are convex whereas the teleoconch whorls are flat. The spiral sculpture bears a prominent first adapical spiral cord which forms a weak subsutural collar. The spiral cords are regularly spaced except for the first (adapical) and last (abapical) cords which have a slightly larger space between the central cords of the spire. The reticulated aspect of the sculpture is maintained on the base of the shell.

The present species has a sculpture that is quite similar to Alvania oceani (d'Orbigny, 1852) but differs consistently in having a more prominent sculpture, with ribs being less prominent than in $A$. oceani; other differences include the absence of varices on early teleoconch whorls, the absence of an umbilical chink, and the overall shape being less elongated than in A. oceani. Another similar species from the Aquitanian of SW France is Alvania mariae (d'Orbigny, 1852) which has flat early teleoconch whorls, a thicker shell, about 7 axial ribs and a smaller aperture.

Alvania areolifera (Sandberger, 1863) from the Oligocene of the Paratethys, as illustrated by Garilli \& Parrinello (2014), has a similar spiral sculpture with closely-spaced spiral cords at the middle of each whorl, but this species has a thicker shell, more prominent axial sculpture and finer and more numerous spiral cords.

Alvania critica Boettger, 1907 differs in having a more pronounced axial sculpture and a smaller aperture as illustrated from the middle Miocene of Turkey (Landau et al. 2013). Alvania perregularis (Sacco, 1907) has a more elongated aspect, a more finely reticulated teleoconch sculpture, a more prominent subsutural collar and a smaller aperture (Landau et al. 2013).

\section{Alvania transiens (Sacco, 1895)}

(Fig. 5H1-H4)

Alvania (Acinopsis) sculpta? var. transiens Sacco, 1895b: 27.

Alvania (Alvania) transiens - Tămaș et al. 2013: 61, fig. 2 i.

Alvania transiens - Landau et al. 2013: 73, pl. 6, fig. 8 (cum syn.).

Material EXAMINED. - Sample F11: AMPG(IV) 2455-2459 (five specimens).

Dimensions. - Maximum height: $3.25 \mathrm{~mm}$.

Distribution. - Early Miocene. Aquitanian. Proto-Mediterranean Sea: Greece (this paper); Paratethys: Austria (Landau et al. 2013). Burdigalian. Proto-Mediterranean: Italy (Sacco 1895b).

Middle Miocene. Proto-Mediterranean Sea: Turkey (Landau et al. 2013); Paratethys: Austria (Cossmann 1921; Kowalke \& Harzhauser 2004), Hungary (Strausz 1966), Poland (Bałuk 1975), Romania (Tămas et al. 2013).

Late Miocene. Proto-Mediterranean Sea: Italy (Sacco 1895b).

Early Pliocene. central Mediterranean: Italy (Sacco 1895b).

\section{DESCRIPTION}

Shell elongated; protoconch conical, of 2.5 slightly inflated whorls. Four rather flat teleoconch whorls with reticulated sculpture of 9-10 axial ribs and 5 regularly spaced spiral cords, third cord significantly weaker. Base with 5 spiral cords, axial sculpture intersects the 3 first spiral cords thus maintaining the reticulated aspect; 2 spiral cords thick and prominent. Aperture tear-drop shaped; no umbilicus, inner lip smooth, outer lip missing in all specimens. 


\section{REMARKS}

Very characteristic species, due to its particular sculpture, elongated shape and conical protoconch. The early Miocene Alvania venus (d'Orbigny, 1852) is slightly reminiscent of $A$. transiens due to its prominent, reticulated sculpture. Kowalke \& Harzhauser (2004) discussed the relationship between $A$. transiens and $A$. venus; Landau et al. (2013) presented a full list of synonymy which also illustrated the similarities of the two species. Another species with distinct cancellate sculpture is Alvania falsivenus Lozouet, 2015 from the Early Oligocene of SW France (Lozouet 2015). It differs from the present species in having a less elongate protoconch and shell, and a less pronounced sculpture in early teleoconch whorls.

Superorder LATROGASTROPODA Bouchet et al. 2017 Superfamily CYPRAEOIDEA Rafinesque, 1815

Family CyPraeidae Rafinesque, 1815

\section{REMARK}

Description is made following Dolin \& Lozouet (2004) and Landau et al. (2013).

\section{Genus Praerosaria Dolin \& Lozouet, 2004}

TyPE SPECIES. - Cypraea (Proadusta) splendens var. exflaveola Sacco, 1894 (= Praerosaria exflaveola (Sacco, 1894)). Early Oligocene (Rupelian), France.

\section{?Praerosaria sp.}

(Fig. 10A-H)

MATERIAL EXAMINED. — Sample F11: AMPG(IV) 2460 (one specimen). DiMENSIONS. — Length: $17.00 \mathrm{~mm}$; height: $8.50 \mathrm{~mm}$; width: $10.50 \mathrm{~mm}$. Distribution. - Early Miocene. Proto-Mediterranean Sea: Greece (this paper)

\section{DESCRIPTION}

Shell small, solid, pyriform, posteriorly swollen. 18 closely spaced columellar teeth, 22 closely spaced labral teeth, fossula convex, smooth with 4 faint columellar teeth apically; terminal fold moderately developed. Venter smooth, convex; outer lip smooth convex. Anterior marginated on both left and right profiles. Left profile rounded; right profile angled from anterior to posterior margins. Posterior edge with callus and with marginated, less inflated in profile. Aperture moderately sigmoidal, narrow slightly widening anteriorly. Siphonal canal wider than anal canal.

Preserved colour pattern consists of two series of faded punctuations; posteriorly a more distinct disc is present.

\section{REMARKS}

This species is most likely represented by two more specimens that are poorly preserved, broken and deformed. The generic assignment is uncertain since the intra-specific morphological variation cannot be assessed.

Apical and adapical margins, narrow aperture with small teeth, convex-inflated ventral and outer lip and distinguishable line on the right profile seem to be the key characters shared by all of the species of Praerosaria as pictured by Dolin \& Lozouet (2004).

Most of the species of the then new genus Praerosaria described by Dolin \& Lozouet (2004) are of similar dimensions to the Greek specimen. Morphologically, the present species is close to the type species of the genus, P. exflaveola (Sacco, 1894), by having marginated edges, a similar terminal fold, and almost the same number of closely-spaced teeth. Another similar species form the Chattian of the Aquitaine Basin (SW France) is P. charlenae Dolin \& Lozouet, 2004 which has slightly more prominent columellar denticles and a less inflated shell dorsally. Indeed, all of the species of Praerosaria seem to be uniform in shell characters, presenting variations that mainly affect the number of columellar and labial denticles and width of the outer lip.

\section{Superfamily XeNOPHOROIDEA Troschel, 1852 (1840)} Family Xenophoridae Troschel, 1852 (1840)

Genus Xenophora Fischer von Waldheim, 1807

TyPe SPECIES. - Xenophora laevigata Fischer von Waldheim (= Xenophora conchiliophora (Born, 1870)), subsequent designation by Gray (1847). Recent, Caribbean.

\section{Xenophora sp.}

(Fig. 5I1-I4)

Material examined. - Sample F10: AMPG(IV) 2461 (one specimen).

DimENSIONS. - Mean diameter: $5.10 \mathrm{~mm}$ (incomplete).

Distribution. — Early Miocene. Proto-Mediterranean Sea: Greece (this paper).

\section{DESCRIPTION}

A fragment comprising 5 flat, teleoconch whorls shouldered on the abapical suture; apical angle $80^{\circ}$. Suture regular, deeply incised; small circular grains are attached along the suture. Base and aperture of the shell missing.

\section{REMARKS}

Due to the fragmentary preservation a clear identification is difficult. The apical angle is similar to $X$. deshayesi (Michelotti, 1847) and $X$. italica (Grateloup, 1845); the apex and first teleoconch whorls of the specimen from Felli are most similar to $X$. italica mainly because of the flattened whorls and the linear suture that is visible when not obstructed by the agglutinated elements as it is observed for this species in Landau et al. (2013). 
According to Ponder (1983), important characters for the separation of species of Xenophoridae are missing from the specimen of Felli, such as the sculpture and shape of the base, the width of the peripheral flange, the umbilical characters and the shape of the basal lip. The characters used here are the spire angle, the shape of the whorls and the mode of attachment of particles. Like the specimen from Felli, $X$. italica is reported to agglutinate smaller-sized objects such as sand grains and small shell fragments (Landau et al. 2013). Nevertheless, it is doubtful that the specimen from Felli is conspecific with $X$. italica, as this species is known so far exclusively from middle Miocene localities (Landau et al. 2013).

Xenophora cumulans (Brongnart, 1823) sensu Harzhauser (2004) from the Oligocene of the Mesohellenic Basin is distinctly different, mainly by having an apical angle that varies between 90 and $100^{\circ}$.

Xenophorids are known to be deposit feeders living on mobile bottoms (Ponder 1983).

Order NEOGASTROPODA Wenz, 1938

Superfamily VOLUTOIDEA Rafinesque, 1815

Family VoluTidae Rafinesque, 1815

Genus Athleta Conrad, 1853

TyPe SPECIES. - Voluta rarispina Lamarck, 1811, by original designation. Early Miocene, Europe (Aquitane, France).

\section{Athleta rarispina (Lamarck, 1811)}

(Fig. 6C1-C4)

Voluta rarispina Lamarck, 1811: 79.

Athleta rarispina - Landau et al. 2013: 205, pl. 68, fig. 2; pl. 80, fig. 4 (cum syn.).

Material examined. - Sample F11: AMPG(IV) 2462, 2463 (two specimens).

Dimensions. - Maximum height: $39.0 \mathrm{~mm}$.

Distribution. — Latest Oligocene-Earliest Miocene. Paratethys: Hungary (Báldi 1973).

Early Miocene. NE Atlantic: France (Peyrot 1928); Proto-Mediterranean Sea: Italy (Sacco 1890), Turkey (İslamoğlu 2004); Paratethys: Germany (Landau et al. 2013).

Middle Miocene. NE Atlantic: France (Peyrot 1928); Proto-Mediterranean Sea: Turkey (Landau et al. 2013); Paratethys: Austria (Hörnes 1856), Poland (Bałuk 1997), Hungary (Strausz 1966).

Late Miocene. Proto-Mediterranean Sea: Italy (Landau et al. 2013), Greece (Symeonidis 1966), Turkey (İslamoğlu \& Taner 2003).

\section{REMARKS}

Two specimens recovered from the present material bearing the characteristic features of Athleta rarispina (Lamarck, 1811), with few spiral lines in the abapical part of the shell and three columellar folds (as opposed to A. ficulina (Lamarck, 1811) that has more numerous folds). Protoconch and early teleoconch features are poorly preserved. The larger of the two specimens has a somewhat irregular sculpture, with irregularly formed spines (forming different angles relative to the surface of the shell) and two growth stops that affect the overall appearance of the sculpture by attenuating two rows of spines.

A full list of synonymy is provided by Landau et al. (2013), which also illustrates the confusion of $A$. rarispina and $A$. ficulina due to their overall similar morphologies, while bringing out the differences of the shells (including the different colouration patterns)

In the Early Miocene of Greece, only A. ficulina has been reported from both the Aquitanian and the Burdigalian of the Mesohellenic Basin so far (Harzhauser et al. 2002).

\section{Superfamily BUCCINOIDEA Rafinesque, 1815 \\ Family Columbellidae Swainson, 1840}

Genus Costoanachis Sacco, 1890

TYPE SPECIES. - Columbella turrita Sacco, 1890 (= Costoanachis saccostata Radwin, 1968), by original designation.

\section{Costoanachis cf. terebralis (Grateloup, 1834)}

(Fig. 6A1, A2)

cf. Nassa terebralis Grateloup, 1834: 271, no. 512.

cf. Costoanachis terebralis - Landau et al. 2013: 188, pl. 28, fig. 11, pl. 66, fig. 8 , pl. 67, fig. 1 (cum syn.).

Material eXAmined. - Sample F11: AMPG(IV) 2464-2466 (three specimens); sample F12: AMPG(IV) 2467 (one specimen).

Dimensions. - Maximum height: $5 \mathrm{~mm}$.

Distribution. - Costoanachis terebralis, Early Miocene. NE Atlantic (Aquitanian-Burdigalian): France (Peyrot 1925; Lozouet et al. 2001); North Sea Basin (late Burdigalian-Langhian): the Netherlands (A.W. Janssen 1984), Germany (Stein et al. 2016).

Costoanachis terebralis, Middle Miocene. NE Atlantic: France (Peyrot 1925; Landau et al. 2013); Proto-Mediterranean Sea: Turkey (Landau et al. 2013); Paratethys: Poland (Bałuk 1995), Austria (Hörnes 1852), Hungary (Strausz 1966).

Costoanachis terebralis, Late Miocene. NE Atlantic: France, Portugal (Landau et al. 2013).

Costoanachis cf. terebralis, Proto-Mediterranean Sea: Greece (this paper).

\section{REMARKS}

The specimens recovered from the present material are very close to Costoanachis terebralis (Grateloup, 1834), which is a rather widespread European species. Its members present morphological variations that mainly concern the width of the shell and the spacing of axial sculpture. The present specimens are on the more slender side of the morphology, most similar to the specimens described in A.W. Janssen (1984).

It differs from $C$. corrugata (Brocchi, 1814) in having a smaller shell and no spiral sculpture, although some very inconspicuous spiral threads are observed between the axial ribs in a juvenile specimen from Felli. The protoconch is multispiral and dome-shaped, the corrosion of the recovered shells does not allow for a detailed description. 
Family MeLongENIDAE Gill, 1871 (1854)

Genus Melongena Schumacher, 1817

TYPE SPECIES. - Melongena fasciata Schumacher, 1817, by monotypy. Recent, Carabbean.

\section{Melongena lainei (de Basterot, 1825)}

(Fig. 11A-C)

Pyrula lainei de Basterot, 1825: 67, pl. 7, fig. 8.

Melongena lainei - Sacco 1904: 32, pl. 9, figs 23, 24. - Lozouet et al. 2001: 62, pl. 28, figs 1a \& b, 2, 3 (cum syn.). - Harzhauser \& Kowalke 2001: 365, fig. 6.2. — Harzhauser 2007: 106, pl. 6, fig. 3. - Lozouet 2014: 285, fig. 209 A-G.

MATERIAl EXAMined. - AMPG(IV) 2467, 2468 (two specimens).

Dimensions. — Maximum height: 98.0 mm (incomplete).

Distribution. - Late Oligocene. Paratethys: Hungary (Báldi 1973); Indo-Pacific Ocean: Oman (Harzhauser 2007).

Early Miocene. Aquitanian. NE Atlantic: France (Lozouet et al. 2001; Lozouet 2014); Proto-Mediterranean Sea: Greece (Harzhauser \& Kowalke 2001); Burdigalian. NE Atlantic: France (Lozouet et al. 2001; Lozouet 2014); Proto-Mediterranean Sea: Italy (Sacco 1904).

\section{REMARKS}

Two specimens of the species were recovered, that can be easily distinguished from other species of Melongena mainly by having a spiral sculpture of spiral angular cords separated by deep furrows (of variable width), an elongated slightly pyriform shape, and has a single row of shoulder spines.

Melongena laine $i$ has been found in the neighbouring location of Agapi in the Aquitanian of the Mesohellenic Basin (Harzhauser \& Kowalke 2001). Melongena lainei semseyiana (Erdös, 1900) is found in the late Oligocene of the Mesohellenic Basin; it is considered to represent a chrono-subspecies (Harzhauser 2004) and is treated as belonging to the M. semseyana lineage by Landau et al. (2013). In the middle Miocene of the Proto-Mediterranean (Turkey), this melongenid is replaced by M. jaapi Landau, Harzhauser, İslamoğlu \& Silva, 2013, a species easily distinguished from $M$. lainei in having shorter spires and a more inflated last whorl.

Modern representatives of Melongena live in the intertidal zone (some can be found up to depths of $30 \mathrm{~m}$ ) of the Caribbean, the Panama, and Indo-Pacific bio-provinces and are predators mainly on bivalves (including burrowing species) (Lozouet \& Londeix 2014b). In the fossil record, $M$. laine $i$ is present in brackish-water paleocommunities in the Proto-Mediterranean during the Aquitanian and the Burdigalian (Harzhauser \& Kowalke 2001; Lozouet et al. 2001).

\section{Superfamily TURBINELLOIDEA Rafinesque, 1815}

\section{Family COSTELLARIIDAe MacDonald, 1860}

\section{REMARK}

Costellariidae is a diverse family of carnivorous gastropods that are widely distributed in tropical and temperate latitudes today with some genera being infaunal (Fedosov et al. 2015, 2017; Vermeij 2017). The phylogenetic relationships have shown the family to be monophyletic (Fedosov et al. 2015), and the generic taxonomy was rearranged by Fedosov et al. (2017).

\section{Genus Pusia Swainson, 1840}

TYPE SPECIES. - Mitra microzonias Lamarck, 1811, by monotypy. Recent, Indo-Pacific.

\section{REMARK}

For a discussion on the phylogenetic relationships and the taxonomic status of the genus Pusia Swainson, 1840 see Fedosov et al. (2017).

\section{Pusia cf. pyramidella (Brocchi, 1814)}

(Fig. 6B[1,2])

cf. Voluta pyramidella Brocchi, 1814: 318, pl. 4, fig. 5.

cf. Pusia pyramidella - Landau et al. 2013: 215, pl. 34, figs 7-9; pl. 68, fig. 9 (cum syn.).

Material eXamined. — Sample F11: AMPG(IV) 2469-2472 (four specimens).

Dimensions. — Maximum height: $3.20 \mathrm{~mm}$.

Distribution. - Early Miocene. Proto-Mediterranean Sea: Greece (this paper).

Early-Middle Miocene. North Sea Basin (A.W. Janssen 1984).

Middle Miocene. Proto-Mediterranean Sea: Turkey (Landau et al. 2013).

Late Miocene. Proto-Mediterranean Sea: Italy (Landau et al. 2013). Early Pliocene. Western and central Mediterranean (Landau et al. 2013).

Late Pliocene. Central Mediterranean (Malatesta 1974; Landau et al. 2013).

\section{REMARKS}

Although the protoconchs of the recovered specimens are corroded, the sculpture and the overall shape of the shells are indicative of Pusia pyramidella. As Landau et al. (2013) mention, this species has many similarities with $P$. ebenus (Lamarck, 1811) but differs in protoconch sculpture, a feature that cannot be assessed here. Most of the specimens from Felli bear ribs on early teleoconch whorls that dissipate and are absent on later whorls. All of the specimens are juveniles, showing the characteristic sculpture of the species on the first four teleoconch whorls.

A full list of synonyms and a discussion on related species is presented in detail in Landau et al. (2013). Due to the conchological similarities with Pusia ebenus (Lamarck, 1811), which is assigned to Pusia (Ebenomitra) subgenus by Fedosov et al. (2017), we chose to include the present species in the genus Pusia with no certainty regarding its subgeneric affinities. 
Superfamily CONOIDEA Fleming, 1822

REMARK

Conoidean gastropods are predatory carnivores (Uribe et al. 2017); the family Mangeliidae includes infaunal species (Vermeij 2017).

Family CONIDAE Fleming, 1822

\section{REMARK}

The taxonomy of Recent representatives of this hyperdiverse family of predatory gastropods has become more stable after molecular phylogenetic studies (Puillandre et al. 2014). For fossil species, a thorough taxonomic revision of Paratethys Conidae by Harzhauser \& Landau (2016) sheds light on the previous confusion of chresonyms; it also gives a clear description of generic characters that we follow in the present work.

\section{Genus Lautoconus Monterosato, 1923}

Type SPECIES. - Conus mediterraneus Hwass in Bruguière, 1792 (= Lautoconus ventricosus (Gmelin, 1791)).

\section{?Lautoconus sp.}

(Fig. 12A-F)

MATERIAL EXAMINED. — Sample F10:AMPG(IV) 2473 (one specimen).

Dimensions. - Height: $26.0 \mathrm{~mm}$; width: $14.5 \mathrm{~mm}$.

DistRibution. — Early Miocene. Proto-Mediterranean Sea: Greece (this paper).

\section{DESCRIPTION}

Shell inflated, sides slightly convex. Protoconch not preserved. Moderately low spire; whorl tops with 3 cords; last whorl with prominent, slightly rounded shoulder. Spiral sculpture in adapical half of the shell, consists of irregularly-spaced striae. Aperture poorly preserved, appears moderately wide. Colour pattern consists of irregularly-spaced dots of variable sizes.

\section{REMARKS}

The specimen recovered in the present material although incomplete, shows some characters that would place it closer to the genus Lautoconus Monterosato, 1923. These are mainly the whorl tops with sculpture, the shouldered last whorl and the spiral sculpture at the base of the shell. Some doubts arise since the early teleoconch spiral structure cannot be assessed and the subsutural flexure cannot be measured due to the preservation of the specimen. This does not allow for a certain attribution to the genus Lautoconus. Nevertheless, the present specimen has similar spiral and whorl top sculpture with the type specimen of the genus.

The species seems to have only a primary colour pattern, with the bands of dots being equidistant whereas spirally, their disposition is irregular (distance between each dot). The pattern is comparable to that of Kalloconus berghausi (Michelotti, 1847) from the middle Miocene of Turkey as illustrated in Landau et al. (2013).

Family Mangelindae P. Fischer, 1883

Genus Mangelia Risso, 1826

TYPE SPECIES. - Mangelia striolata Risso, 1826, subsequent designation by Herrmannsen (1852). Recent, Mediterranean.

$$
\begin{aligned}
& \text { Mangelia (s.l.) sp. } \\
& \text { (Fig. 6D1-D4) }
\end{aligned}
$$

MATERIAL EXAMINED. — Sample F11: AMPG(IV) 2474-2477 (four incomplete specimens).

DiMENSIONS. - Maximum height: $3.66 \mathrm{~mm}$ (incomplete); maximum width: $1.55 \mathrm{~mm}$.

Distribution. — Early Miocene. Proto-Mediterranean Sea: Greece (this paper).

\section{DESCRIPTION}

Protoconch multispiral, dome shaped, eroded, consists of 3 whorls, maximum diameter is $400 \mu \mathrm{m}$. Teleoconch of 3.5 whorls; axial sculpture composed of opisthocline regularly-spaced rounded ribs, about 12 on each whorl; fine axial regularly spaced growth lines. Spiral sculpture has four main equidistant cords; the second cord is more prominent and forms an angle of the spire from the second teleoconch whorl on. Spaces between cords occupied by secondary finer cords, two between each main spiral cord. Microsculpture consists of finer and irregularly spaced spiral cords. Intersections of growth lines and cords forms beads. Suture smooth; aperture missing; observed inner lip smooth.

\section{REMARKS}

The preservation state of the specimens does not allow a certain generic assignment. In one specimen of the studied material, part of the protoconch II sculpture is preserved; it consists of eroded axial riblets. The overall shape and sculpture that consists of finely beaded cords, is typical of members of the family.

A morphologically similar species from the Middle Miocene (Serravallian) of Turkey is Mangelia sp. (Landau et al. 2013), with a similar spiral sculpture, yet less angular whorls than the present species.

A similar species from the Miocene of the North Sea Basin is Sorgenfreispira plicatelloides (Nordsieck, 1979) (A.W. Janssen 1984; Moths et al. 2010); it has a similar protoconch in shape and shouldered teleoconch whorls. Sorgenfreispira sorgenfreii (Nordsieck, 1979) is another species from the Miocene of the Netherlands that has some similarities (protoconch shape and teleoconch sculpture) but with less axial ribs and more rounded whorls. In the stratotype area of the Aquitanian (Aquitaine, France), there are no recorded species of Sorgenfreispira, but other Mangeliidae are present. Namely Bela elegantissima (Peyrot, 1931) which resembles the present species in having a similar teleoconch sculpture and shouldered whorls, but is much larger in size (maximum height about $8 \mathrm{~mm}$ ) and has six teleoconch whorls. 


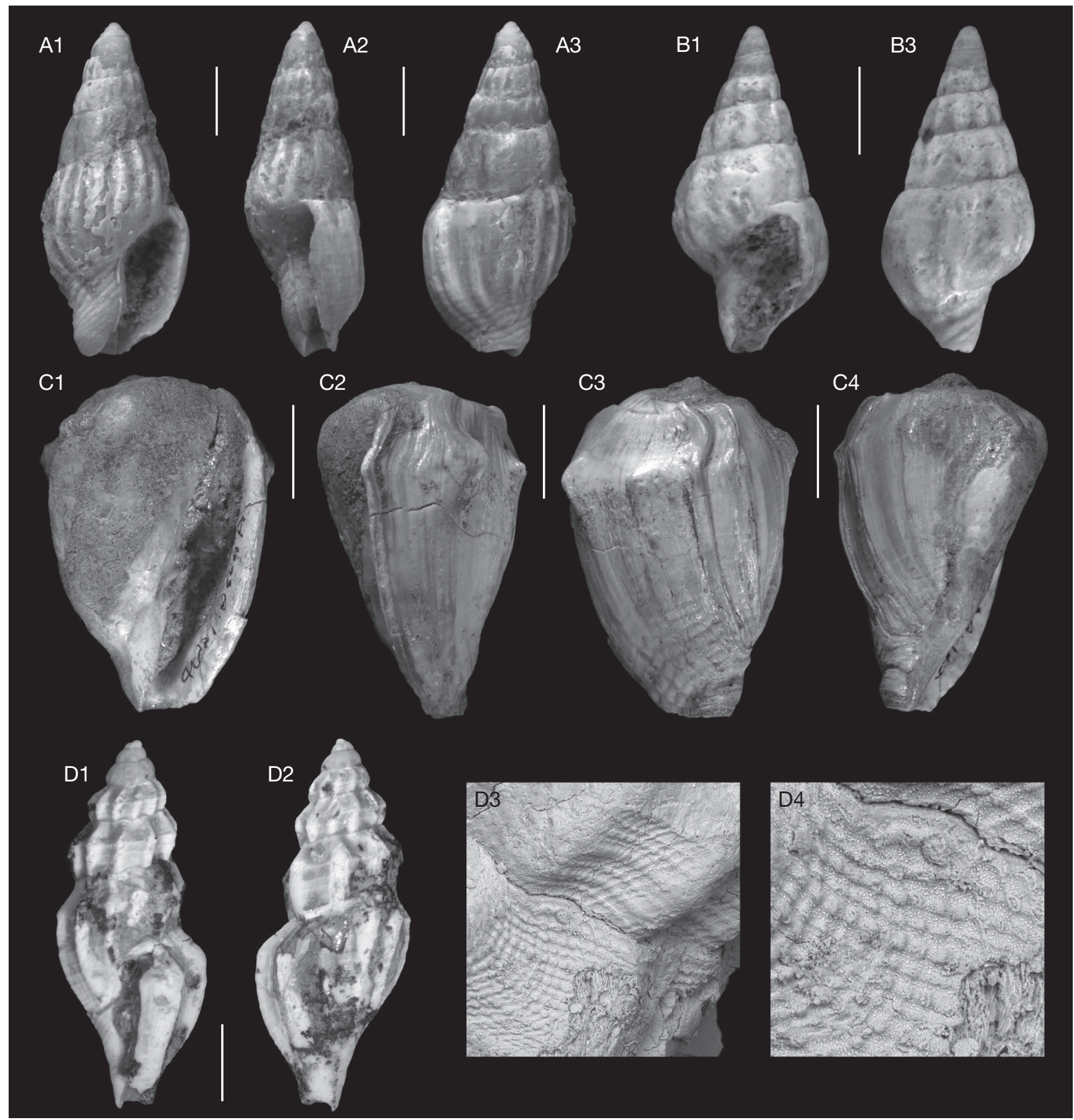

FIG. 6. - A1-A3, Costoanachis cf. terebralis (Grateloup, 1834), AMPG(IV) 2467; B1, B2, Pusia cf. pyramidella (Brocchi, 1814), AMPG(IV) 2469; C1-C4, Athleta rarispina (Lamarck, 1811), AMPG(IV) 2462; D1-D4, Mangelia (s.l.) sp.: D1, D2, AMPG(IV) 2474; D3, D4, AMPG(IV) 2475, detail of microsculpture (SEM images). Scale bars: A1, A2, B1, B2, D1, D2, 1 mm; C1-C4, 10 mm; D3, $300 \mu \mathrm{m}$; D4, $100 \mu \mathrm{m}$.

Subclass HETEROBRANCHIA Burmeister, 1837 Superfamily MATHILDOIDEA Dall, 1889 Family MATHILDIDAE Dall, 1889

Genus Mathilda Semper, 1865

TYPE SPECIES. - Turbo quadricarinatus Brocchi, 1814 (= Mathilda quadricarinata (Brocchi, 1814)), subsequent designation by de Boury (1883). Pliocene, Italy.
Mathilda sp.

(Fig. 7A1-A3)

MATERIAL EXAMINED. — Sample F10: AMPG(IV) 2478 (one specimen). DiMENSIONS. - Height: $3.14 \mathrm{~mm}$.

Distribution. - Early Miocene. Proto-Mediterranean: Greece (this paper). 


\section{DESCRIPTION}

Elongated turriculate shell; apical angle $c .29^{\circ}$. Protoconch consisting of two whorls, smooth, bulbous, perpendicular to the teleoconch; diameter $500 \mu \mathrm{m}$. Teleoconch with relatively flat whorls; sculpture consisting of three equidistant spiral cords; two cords placed immediately below adapical and above abapical suture; third cord in mid-whorl, more prominent. Fourth very fine spiral cord appears between adapical two cords on fourth teleoconch whorl. Axial sculpture of regularly spaced fine riblets, forming beads at intersections with spiral cords. Suture impressed, emphasized by adjoining beaded spiral cords; aperture missing.

\section{REMARKS}

Mathilda peyroti (Cossmann \& Peyrot 1922) is the most similar species, with the main difference being that the fourth, finer cord appears on whorl 5 of the teleoconch. The apical angle ranges from 20 to $23^{\circ}$ for $M$. peyroti (Cossmann \& Peyrot 1922), whereas for the present specimen it is of about $29^{\circ}$. The present species also differs from $M$. granosa (Borson, 1821), in having less prominent sculpture and a thicker cord below the suture. Another Miocene species is $M$. margaritula, which differs mainly by forming more prominent nodes at the intersections of cords and axial ribs.

According to Gründel \& Nützel (2013), Mathildidae feed on Cnidaria.

Superfamily ACTEONOIDEA d'Orbigny, 1843

Family ACTEONIDAE d'Orbigny, 1843

TyPE SPECIES. - Bulla tornatilis Linnaeus, 1758, by original designation. Recent, Europe.

\section{REMARK}

The genus Acteon is here used based on shell morphology, whereas modern species are assigned in Acteonidae genera based on their radula.

\section{Acteon cf. pinguis d'Orbigny, 1852} (Fig. 7B1, B2)

cf. Acteon pinguis d'Orbigny, 1852: no. 521, 36. - Peyrot 1932: 157, no. 1376, pl. 11, figs 55-57, pl. 14, figs 12, 13. - Lozouet et al. 2001: 79. - Harzhauser 2002: 125, pl. 12, fig. 7.

Material EXAMINED. - Sample F10: AMPG(IV) 2479-2481 (three specimen); sample F11: AMPG(IV) 2482, 2483 (two specimens); sample F12: AMPG(IV) 2484-2487 (four specimens).

Dimensions. — Maximum height: $1.85 \mathrm{~mm}$.

Distribution. - Early Miocene. Aquitanian. NE Atlantic: France (Aquitaine Basin) (Peyrot 1932; Lozouet et al. 2001); Proto-Mediterranean: Greece (this paper). - Burdigalian. NE Atlantic: France (Aquitaine Basin) (Peyrot 1932); Paratethys: Austria (Harzhauser 2002).

\section{DESCRIPTION}

Juvenile and incomplete specimens with intorted smooth protoconch. Apical angle of $55^{\circ}$. Two teleoconch whorls, sculpture typi- cal with regularly-spaced pitted grooves, suture deeply impressed; aperture tear-drop shaped, no umbilicus, outer lip regularly convex.

\section{REMARKS}

A single species of 'Acteon' has been found, represented mainly by juveniles. The sculpture, apical angle coincide with those of $A$. pinguis but the juvenile and incomplete specimens does not allow a clear identification. Variation in sculpture consists of the grooves that bear less prominent pits and have a smoother aspect abapically. The last whorl of the specimens observed has slightly deeper grooves which could possibly be a feature dominating the sculpture of later whorls.

The shape of the shell and the convexity of the whorls are reminiscent of Acteon semistriatus (Férussac, 1822). The sculpture and overall morphology of the recovered specimens is most similar to $A$. pinguis d'Orbigny, 1852 . Nevertheless, the protoconch seems slightly wider and less inflated, which could be due to intraspecific variability. Moreover, specimens recovered show various traces of predation from molluscs and possibly decapods.

Order RINGICULIDA Bouchet et al. 2017

Superfamily RingICUlOIDEA Philippi, 1853

Family Ringiculidae Philippi, 1853

Genus Ringicula Deshayes, 1838

TYPE SPECIES. - Ringicula ringens (Lamarck, 1804), subsequent designation by Gray (1847). Eocene, France.

\section{Ringicula minor (Grateloup, 1838)}

(Fig. 7C1, C2)

Auricula ringens var. b. minor Grateloup, 1838: 286, pl. 6, fig. 8 .

Ringicula minor - Landau et al. 2013: 326, pl. 52, fig.16, pl. 76, fig. 14, pl. (cum syn.).

Material eXamined. - Sample F11: AMPG(IV) 2488-2531 (44 specimens); sample F12: AMPG(IV) 2532-2540 (nine specimens).

Dimensions. - Maximum height: $4.70 \mathrm{~mm}$.

Distribution. - Early Miocene. NE Atlantic: France (Peyrot 1932; Lozouet et al. 2001; Lesport \& Cahuzac 2005; Cahuzac et al. 2012); Proto-Mediterranean Sea: Greece (this paper); Paratethys: Slovakia (Harzhauser et al. 2011).

Middle Miocene. NE Atlantic: France (Peyrot 1932); Proto-Mediterranean Sea: Turkey (Landau et al. 2013); Paratethys: Austria (Hörnes 1852), Hungary (Strausz 1966).

\section{REMARKS}

In many specimens the outer lip and the parietal callus are not callous. This was also observed in French representatives of Ringicula minor from the Aquitaine Basin (Lozouet et al. 2001). The large number of fragments documents that this species was among the most frequent species in the shallowmarine assemblage of Felli.

Ringicula minor is a widespread European species (Harzhauser 2014; Landau et al. 2013). 


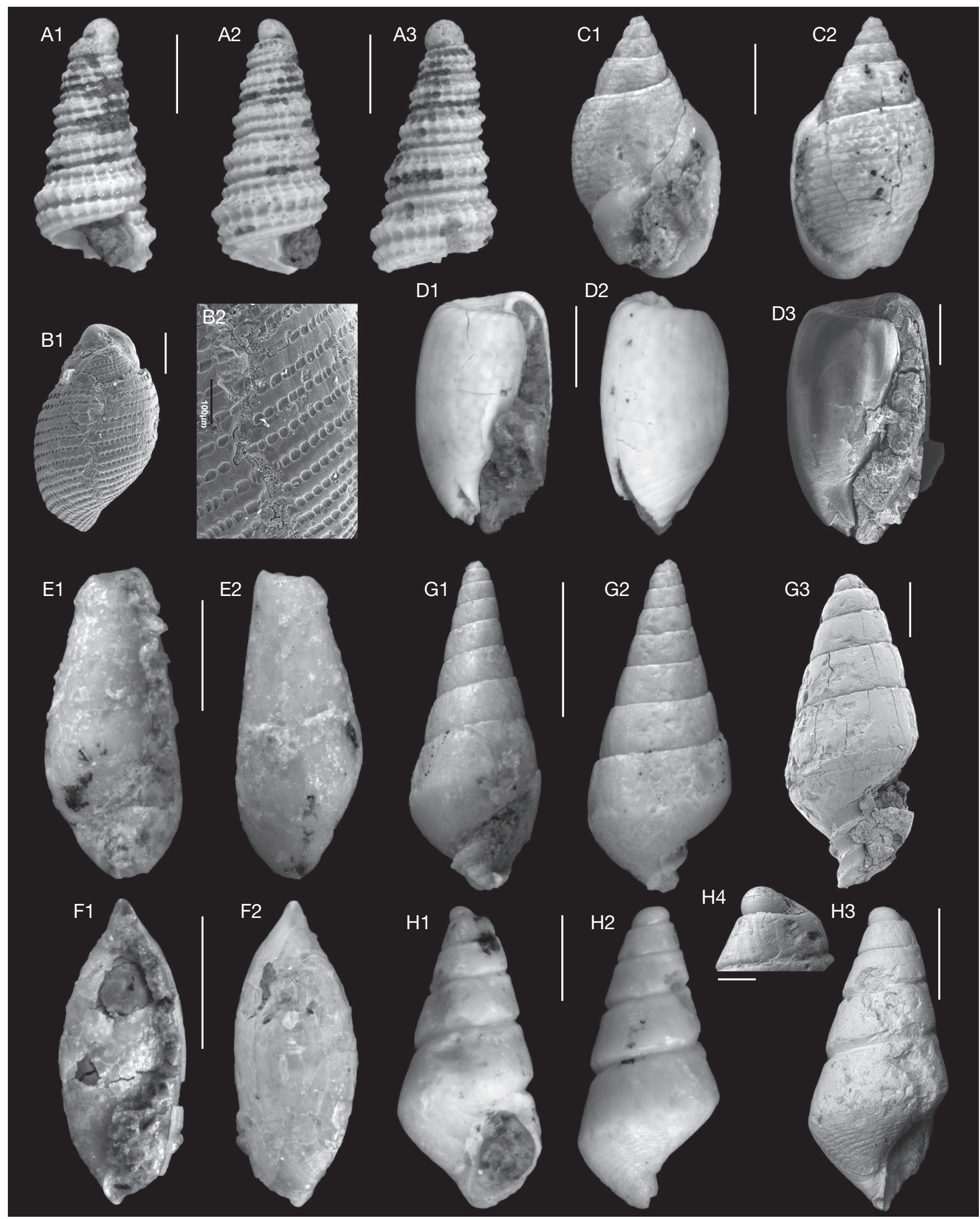

FIG. 7. - A1-A3, Mathilda sp., AMPG(IV) 2478; B1, B2, Acteon cf. pinguis d'Orbigny, 1852: B1, AMPG(IV) 2479 (SEM image); B2, AMPG(IV) 2479, detail of microsculpture (SEM image); C1, C2, Ringicula minor (Grateloup, 1838), AMPG(IV) 2488; D1-D3, Retusa truncatula (Bruguière, 1792): D1, D2, AMPG(IV) 2541; D3, AMPG(IV) 2542 (SEM image); E1, E2, Pyrunculus sp., AMPG(IV) 2545; F1, F2, Volvulella acuminata (Bruguière, 1792), AMPG(IV) 2547; G1-G3, Pyramidella cf. plicosa Bronn, 1838: G1, G2, AMPG(IV) 2554; G3, AMPG(IV) 2555 (SEM image); H1-H3, 'Odostomia' sp. 1, AMPG(IV) 2557; H3, AMPG(IV) 2557

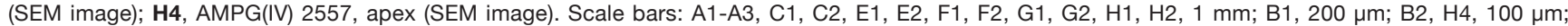
$\mathrm{D} 1, \mathrm{D} 2, \mathrm{H} 3,500 \mu \mathrm{m} ; \mathrm{D} 3, \mathrm{G} 3,400 \mu \mathrm{m}$. 


\section{Order CEPHALASPIDEA P. Fischer, 1883}

\section{REMARK}

Cephalaspidea have been studied recently with an aim to better understand the phylogeny of this diversified order of marine gastropods (Malaquias et al. 2009; Oskars et al. 2015). Even though the relationships between families was clarified by Oskars et al. (2015), the superfamilies Bulloidea Gray, 1827 and Diaphanoidea Odhner, 1914 (1857) remain non monophyletic, with the family Retusidae being paraphyletic.

Superfamily BULLOIDEA Gray, 1827

Family RetUSIDAE Thiele, 1925

\section{Genus Retusa T. Brown, 1827}

Type SPECIES. - Bulla obtusa Montagu, 1803, by subsequent designation (Iredale 1915). Recent, Europe.

\section{Retusa truncatula (Bruguière, 1792)}

(Fig. 7D1-D3)

Bulla truncatula Bruguière, 1792: 377.

Retusa truncatula - Landau et al. 2013: 337, pl. 77, fig. 11 (cum syn.).

Material eXamined. - Sample F11: AMPG(IV) 2541-2544 (four specimens).

Dimensions. — Maximum height: $0.62 \mathrm{~mm}$.

Distribution. - Early Miocene. Proto-Mediterranean Sea: Greece (this paper) (Aquitanian); Paratethys: Austria (Harzhauser 2002) (Burdigalian).

Middle Miocene. NE Atlantic: France (Peyrot 1932); Proto-Mediterranean Sea: Turkey (Landau et al. 2013); Paratethys: Austria (Hörnes 1856; Berger 1953), Poland (Bałuk 1970), Hungary (Strausz 1966). Late Miocene. NE Atlantic: Portugal (Landau et al. 2013), Mediterranean Sea: Italy (Sacco 1896).

Early Pliocene. NE Atlantic: Spain (Landau et al. 2011), central Mediterranean Sea: Italy (Chirli 2013).

Early Pleistocene. central and eastern Mediterranean Sea: Italy (Cerulli-Irelli 1910), Greece (Koskeridou et al. 2009).

Early-Middle Pleistocene. eastern Mediterranean Sea: Greece (Nielsen et al. 2006).

Recent. NE Atlantic, Baltic Sea to Canary Islands and Mediterranean Sea (Thompson 1988; MolluscaBase 2018).

\section{REMARKS}

Juveniles, small specimens and fragments of Retusa truncatula were recovered in the Greek material. The morphology of the specimens of the present material is consistent with the range of variation of $R$. truncatula.

Retusa truncatula has been recorded widely in the fossil record and it is still present in the northeastern Atlantic and Mediterranean (Landau et al. 2013; MolluscaBase 2018). It is possible that we are dealing with a cryptic species since the taxon seems very long-lived and widespread. As Oskars et al. (2015) mention, the phylogenetic relationships of the family should be investigated in detail, which could bring more information relative to the fossil representatives of the family Retusidae.
Genus Pyrunculus Pilsbry, 1895

TYPE SPECIES. - Bulla pyriformis A. Adams in Sowerby, 1850, by monotypy. Recent, China Sea.

\section{Pyrunculus sp.}

(Fig. 7E1, E2)

Material EXAMINED. — Sample F11: AMPG(IV) 2545, 2546 (two specimens [1 incomplete]).

Dimensions. - Maximum height: $2.80 \mathrm{~mm}$.

Distribution. - Early Miocene. Proto-Mediterranean Sea: Greece (this paper).

\section{DESCRIPTION}

Shell small, fragile, elongated pyriform, one whorl visible. Sculpture of fine growth lines. Apex angular, apical umbilicus narrow $(0.34 \mathrm{~mm})$; umbilicus not observable; anterior end rounded; aperture long, wide anteriorly, narrowing abruptly at about $2 / 5$ of its length. Outer lip morphology not preserved.

\section{REMARKS}

One complete specimen and a second, incomplete specimen of a Pyrunculus species are available. The species is reminiscent of the widespread Miocene Pyrunculus elongatus (Eichwald, 1830) but differs in its smaller size, more slender outline and the more pronounced concavity in the upper part of the last whorl. Moreover, its apex is wider and straighter than in P. elongatus. Dorsally, the outline forms an almost straight line on the left side, whereas the right side is more angular, with a small angle at about $2 / 3$ of the height of the shell.

The Greek specimens seem to represent a new species, but due to the low number of available specimens and their moderate preservation; we refrain from describing it formally as new.

Family RHIZORIDAe Dell, 1952

Genus Volvulella Newton, 1891

TYPE SPECIES. - Bulla acuminata Bruguière, 1792, by subsequent designation (Adams 1862). Recent, Europe.

Volvulella acuminata (Bruguière, 1792)

(Fig. 7F1, F2)

Bulla acuminata Bruguière, 1792: 376.

Volvulella acuminata - Landau et al. 2013: 339, pl. 78, fig. 2 (cum syn.).

Material eXamined. — Sample F11: AMPG(IV) 2547-2549 (three specimens).

DimENSIONS. — Maximum height: $2.32 \mathrm{~mm}$.

Distribution. — Early Miocene. Proto-Mediterranean Sea: Italy (Sacco 1897), Greece (this paper). 
Middle Miocene. Proto-Mediterranean Sea: Turkey (Landau et al. 2013); Paratethys: Austria (Berger 1953), Hungary (Strausz 1966); North Sea Basin: the Netherlands (A.W. Janssen 1984), Germany (Moths et al. 2010).

Late Miocene. NE Atlantic (Landau et al. 2013).

Early Pliocene. NE Atlantic, North Sea Basin (Landau et al. 2013); western Mediterranean (Landau et al. 2011); eastern Mediterranean: Greece (Koskeridou et al. 2017).

Early Pleistocene. Central Mediterranean: Italy (Cerulli-Irelli 1910). Recent. Eastern Atlantic, Norway to Angola into Mediterranean (Landau et al. 2013).

\section{REMARKS}

Minute species, with a characteristic pointed apex. The morphology of the shells of the present material is consistent with the representatives of this species. As mentioned for Retusa truncatula, Vollvulela acuminata is either an extremely long lived species or a species complex that includes specimens that have similar and indistinguishable morphologies.

In the Early Miocene the species is missing from the Aquitanian and Loire Basins in France, where Volvulella acuta (Grateloup, 1827) is present (Landau et al. 2013).

Superfamily Cylichnoidea H. Adams \& A. Adams, 1854 Family Cylichnidae H. Adams \& A. Adams, 1854

$$
\text { Genus Cylichna Lovén, } 1846
$$

TyPe SPECIES. - Bulla cylindracea Pennant, 1777 (= Cylichna cylindracea (Pennant, 1777)), subsequent designation by Hermannsen (1852). Recent, Europe.

\section{Cylichna cf. sublaevis (d'Orbigny, 1852)}

cf. Bulla sublaevis d'Orbigny, 1852: 95, nº1772.

cf. Bulla laevis-Grateloup 1837: 400, pl. 3, figs 35, 36 (non Defrance).

cf. Bullinella (Cylichnina) sublaevis - Peyrot 1932: 187, no. 1396 pl. 13, figs 31, 33 .

cf. Cylichna sublaevis - Lozouet et al. 2001: 81, pl. 37, figs 2a, b.

Material EXAmined. - Sample F11: AMPG(IV) 2550-2553 (four specimens).

Dimensions. - Maximum height: $2.20 \mathrm{~mm}$.

Distribution. - Early Miocene. NE Atlantic: France (Aquitaine Basin) (d'Orbigny 1852; Peyrot 1932; Lozouet et al. 2001); ProtoMediterranean Sea: Greece (this paper).

\section{REMARKS}

A species of Cylichna was recovered, whose morphology bears many similarities with Cylichna sublaevis (d'Orbigny, 1852) despite the poor preservation. The shell is subcylindrical, smooth, with sculpture consisting of inconspicuous growth lines; adapically the outer lip rises above the apex and forms a narrow apical perforation. The aperture is partially broken in all specimens; the inner lip is small and bears a small fold. No colour pattern can be observed in the Greek specimens, although it is mentioned by Peyrot (1932) that the species had axial zig-zag-shaped lines. The specimens from Greece seem to be smaller than those mentioned by Peyrot (1932) $(5.5 \mathrm{~mm})$ but this is most probably due to the preservation of these fragile shells in the present material, with larger size specimens being very fragmented.

\section{Superorder PYLOPULMONATA Bouchet et al., 2017}

Superfamily PyramidelloideA Gray, 1840

Family PyRAMIDELLIDAE Gray, 1840

\section{REMARK}

This family has incited many discussions and works over the years both for recent and for fossil species. Almost all of the species are ectoparasites of soft-bodied invertebrates (e.g. polychaete worms and other molluscs) (Dinapoli et al. 2011).

Taxonomic descriptions have been based on the teleoconch morphology and especially on the protoconch according to descriptions and illustrations of Peñas et al. (1996). Works on the phylogenies of the family are few, which complicates the correct assignment of species to genera.

\section{Subfamily Pyramidellinae Gray, 1840}

Genus Pyramidella Lamarck, 1799

TyPE SPECIES. - Trochus dolabratus Linnaeus, 1758 (= Pyramidella dolabrata (Linnaeus, 1758)), by monotypy. Recent, Caribbean.

Pyramidella cf. plicosa Bronn, 1838

(Fig. 7G1-G3)

cf. Pyramidella plicosa Bronn, 1838: 1026, pl. 40, fig. 24.

cf. Pyramidella plicosa - Landau et al. 2013: 304, pl. 52, fig. 5 (cum syn.).

Material eXamined. - Sample F11: AMPG(IV) 2554-2556 (three specimens).

Dimensions. - Maximum height: $5.00 \mathrm{~mm}$, diameter. $2.20 \mathrm{~mm}$.

Distribution. - Early Miocene. Proto-Mediterranean Sea: Italy (Sacco 1892), Greece (this paper).

Middle Miocene. Proto-Mediterranean Sea: Turkey (Landau et al. 2013); North Sea Basin: Belgium (Glibert 1952), Denmark, Germany (Landau et al. 2013), the Netherlands (A.W. Janssen 1984).

Late Miocene. Central Mediterranean: Italy (Sacco 1892); North Sea Basin: Denmark, Belgium (Landau et al. 2013).

Early Pliocene. Western Mediterranean (Landau et al. 2013); central Mediterranean (Malatesta 1974); North Sea Basin (Glibert 1958). Late Pliocene. Central Mediterranean: Italy (Sacco 1892); North Sea Basin (Marquet 1998).

Early Pleistocene. Central Mediterranean: Italy (Cerulli-Irelli 1914).

\section{DESCRIPTION}

Small, moderately slender, high conical shell; apical angle $30^{\circ}$. Protoconch of type A, partially immersed. Teleoconch consisting of seven, flat whorls with narrowly incised suture, resulting in 
faintly gradate spire. Transition into convex base weakly angulated. Aperture tear-shaped with 3 columellar folds and a narrow canal.

\section{REMARKS}

A complete list of synonymy is provided by Landau et al. (2013). Several varieties have been created due to the morphological variability of the species; the length, the angulation and width of the last whorl, and the strength of the three columellar folds. In the present material, only one protoconch was preserved, of type A and partially immersed, therefore no variability can be observed. There is a variation with size of the columellar teeth of the Greek specimens, the smallest specimen bears more prominent folds in contrary to the largest specimen for which they are moderately developed.

The species differs from Pyramidella grateloupi (d'Orbigny, 1852) from the type region (SW France, Aquitaine) in being more slender, having a less incised suture and having a less cyrtoconoid outline.

\section{Subfamily Odostominae Pelseneer, 1928}

Genus Odostomia J. Fleming, 1813

Type SPECIES. - Turbo plicatus Montagu, 1803 (= Odostomia plicata (Montagu, 1903)), subsequent designation by Gray (1847). Recent, Europe.

\section{REMARK}

Odostomia has been used for including Pyramidellidae with a smooth shell and a columellar tooth (Høisæter 2014). Since then, it has included species with these characters that cannot be classified with certainty in other genera of Odostominae. Here, we use it sensu lato.

\section{'Odostomia' s.l. sp. 1}

(Fig. 7H1-H4)

Material eXAmined. - Sample F11: AMPG(IV) 2557 (one specimen).

Dimensions. - Maximum height: $1.75 \mathrm{~mm}$.

Distribution. - Early Miocene. Proto-Mediterranean Sea: Greece (this paper).

\section{DESCRIPTION}

Type C partially immersed tilted protoconch. Teleoconch whorls shouldered, smooth and flat, sutures deeply incised, V-shaped. Sculpture on the base of the shell consists of fine spiral grooves and axial growth lines. Last whorl slightly angular; aperture rhomboid; umbilicus very restricted; columellar tooth moderately developed.

REMARKS

The present species is easily set apart from other Odostomiinae by having a conical shape, a relatively solid shell with flat whorls and very distinct sutures. The partially immersed protoconch forms an acute angle with the first teleoconch whorl of about $45^{\circ}$. The almost indistinguishable subsutural collar gives a shouldered aspect to the whorls and accentuates the sutures.

Morphologically, it is most similar, regarding the shape of the whorls, the protoconch and the aperture, to the recent species Odostomia didyma (Verrill \& Bush, 1900) (= Eulimastoma didymum (Verrill \& Bush, 1900)?). Nevertheless, the genus Eulimastoma Bartsch, 1916 is characterised by spiral microstructure which is not observed on the present specimen, possibly due to the preservation of the shell.

Furthermore, the shape and overall morphology of Odostomia (Pyramistomia) fehrae van Aartsen, Gittenberger \& Goud, 1998 is similar. The latter species is classified in Pyramistomia Cossmann, 1921 at the subgenus level, on grounds of having similarities with Odostomia deubeli Boettger, 1901 (= Pyramistomia deubeli Boettger, 1901) (type species of Pyramistomia) (van Aartsen et al. 1998). In a revision of the genus Eulimastoma Bartsch, 1916, Pimenta \& Absaláo (2004) mention that $O$. (Pyramistomia) fehrae is related. In the present state of knowledge of the apomorphies of these genera, it is not possible to assign the present specimen with certainty, thus its placement in Odostomia s.l.

\section{'Odostomia' s.l. sp. 2}

(Fig. 8A1, A2)

Material EXAMINED. — Sample F11: AMPG(IV) 2558, 2559 (two specimens).

Dimensions. - Maximum height: $1.30 \mathrm{~mm}$.

Distribution. - Early Miocene. Proto-Mediterranean Sea: Greece (this paper).

\section{DESCRIPTION}

Type B planispiral and partially immersed protoconch. Teleoconch of three flat whorls; sculpture consists of inconspicuous orthocline growth lines; sutures impressed. Last whorl angular; umbilicus small and narrow, aperture oval, outer lip missing.

\section{REMARKS}

The shell is short and conical; all specimens have a type B protoconch with an arch-shaped suture (Peñas \& Rolán 2010). The apex of the protoconch forms a concavity to the suture between protoconch and first teleoconch whorl, which is a feature, observed in some specimens with type B partially immersed protoconchs in the genus Eulimastoma. Nevertheless, the present specimen lacks other characters that could place it in the latter genus (inflated suprasutural band, sculpture of the base of the shell).

\section{Genus Megastomia Monterosato, 1884}

TYPE SPECIES. — Odostomia conspicua Alder, 1850, by original designation. Recent, Europe. 


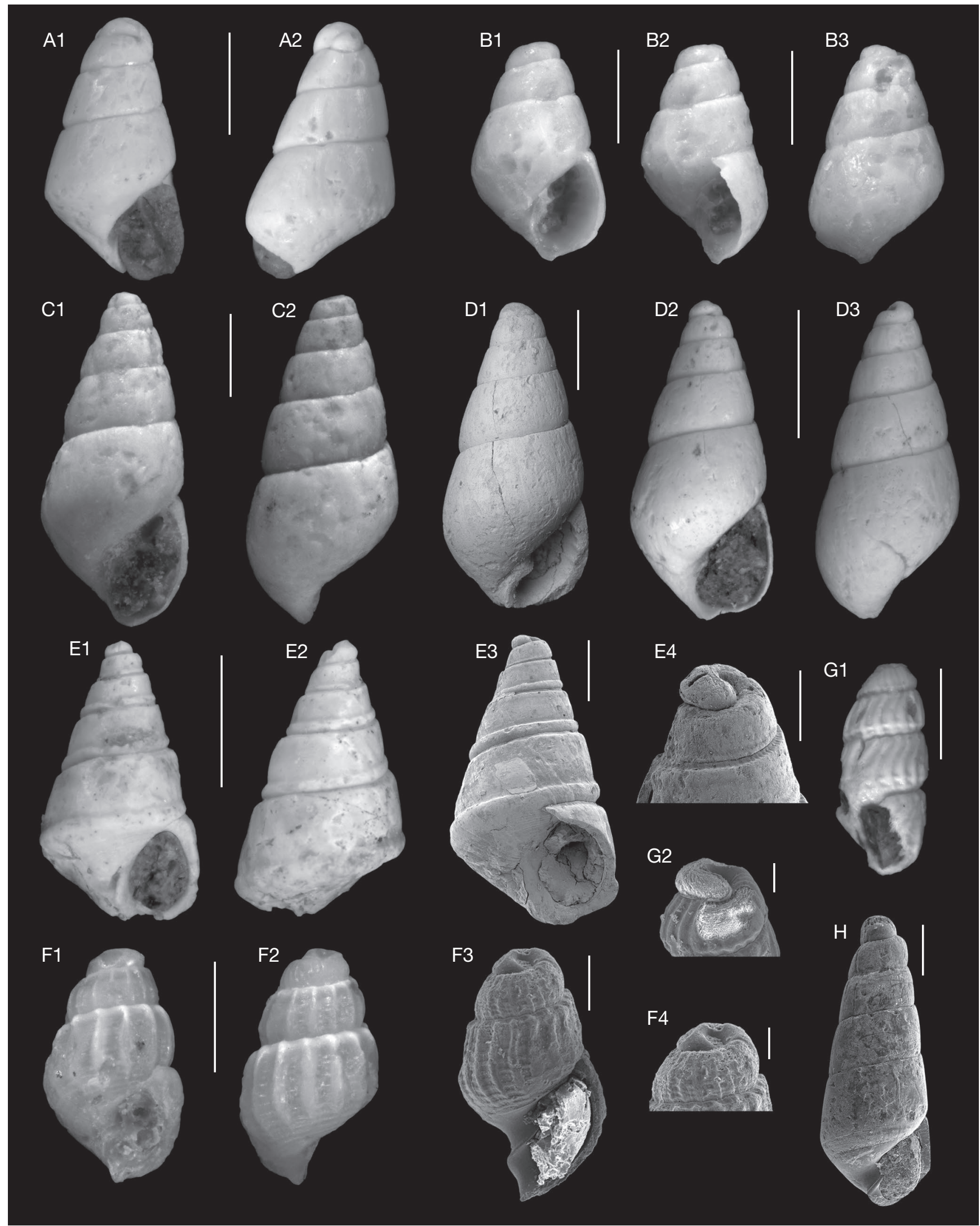

FIG. 8. - A1, A2, 'Odostomia' sp. 2, AMPG(IV) 2558; B1-B3, Megastomia sp. 1, AMPG(IV) 2560; C1, C2, Brachystomia sp., AMPG(IV) 2570; D1-D3, Megastomia sp. 2: D1, AMPG(IV) 2563; D2, D3, AMPG(IV) 2564; E1-E4, Pyramistomia aliakmoni n. sp.: E1, E2, holotype, AMPG(IV) 1500; E3, paratype 1, AMPG(IV) 1501 (SEM image); E4, AMPG(IV) paratype 1, AMPG(IV) 1501, protoconch (SEM image); F1-F4, Parthenina sp. 1: F1, F2, AMPG(IV) 1573; F3, AMPG(IV) 1574 (SEM image); F4, AMPG(IV) 1574, apex (SEM image); G1, G2, Parthenina sp. 2: G1, AMPG(IV) 2575; G2, AMPG(IV) 2575, apex (SEM image); H, ?Syrnola sp., AMPG(IV) 2577

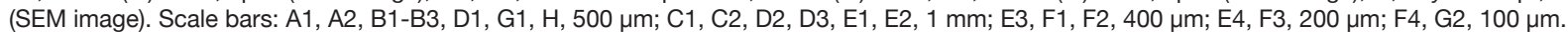




\section{Megastomia sp. 1}

(Fig. 8B1-B3)

Material eXAmined. - Sample F11: AMPG(IV) 2560-2562 (three specimens).

Dimensions. - Maximum height: $1.20 \mathrm{~mm}$.

Distribution. - Early Miocene. Proto-Mediterranean Sea: Greece (this paper).

\section{DESCRIPTION}

Small, solid shell with broad conical outline; spire angle c. $26^{\circ}$. Intorted type $\mathrm{C}$ protoconch of $c .300 \mu \mathrm{m}$ diameter, resulting in very blunt apex. Axial sculpture consisting of inconspicuous, orthocline growth lines. Whorls only faintly convex, sutures impressed and linear. Last whorl inconspicuously angular at periphery; accounting for about $60 \%$ of total height. Columella weakly concave with central columellar tooth; outer lip smooth. Six elongate teeth appear behind aperture in last whorl. Umbilicus reduced to narrow chink.

\section{REMARKS}

The generic placement is based on the presence of elongate teeth behind the outer lip (Peñas \& Rolán 1999; Robba 2013). All available specimens are very small and might represent subadult specimens. The type $\mathrm{C}$ protoconch distinguishes this species from the widespread Miocene to Recent European Megastomia conoidea (Brocchi, 1814). Among the Recent species of Megastomia, only M. lorioli (Hornung \& Mermod, 1924) develops a type C protoconch (Bogi \& Cuneo 1999). This Lessepsian migrant differs from the Aquitanian species from Greece in its strongly incised suture. The extant Odostomia lukisii Jeffreys, 1859 has a very similar shell morphology, with an immersed type $\mathrm{C}$ protoconch, but lack the teeth within the outer lip.

\section{Megastomia sp. 2}

(Fig. 8D1-D3)

Material eXamined. - Sample F11: AMPG(IV) 2563-2569 (seven specimens).

Dimensions. - Maximum height: $2.20 \mathrm{~mm}$.

Distribution. — Early Miocene. Proto-Mediterranean Sea: Greece (this paper).

\section{DESCRIPTION}

Moderately slender, solid shell; apical angle $c .27^{\circ}$. Partially immersed, type B protoconch. Teleoconch comprising four feebly convex, smooth whorls, with inconspicuous microscopical orthocline growth lines separated by impressed sutures. Last whorl attaining about $60 \%$ of total height; slightly angulated at periphery. Columella concave with narrow columellar fold; aperture ovate; outer lip with five observable spiral lines. No umbilicus.

\section{REMARKS}

Two protoconch whorls are visible on the shells (including the nucleus). Type B protoconch and columellar tooth place this shell in the Odostomia group, and the spiral striations of the inner lip in the Megastomia genus. It is also separated from 'Odostomia' sp. 2 of the present material, in having a more immersed protoconch and more rounded whorls.

The overall morphology is similar to M. conoidea with the main difference being that the protoconch of the Greek specimen is of type B a slightly more rounded last whorl. The size and protoconch type coincides with that of Odostomia sp. from the stratotype region of the Aquitanian (Aquitaine Basin, SW France) (Lozouet et al. 2001). Nevertheless, the Greek specimen has a more conical shape and spiral sculpture on the inner lip that differentiates it.

\section{Genus Brachystomia Monterosato, 1884}

TYPE SPECIES. - Odostomia rissoides Hanley, 1844 (= Brachystomia scalaris (MacGuillivray, 1843)), subsequent designation by Crosse (1885). Recent, Europe.

\section{REMARK}

Due to the few shell characters of the genus, species belonging to Brachystomia Monterosato, 1884 have been included in Ondina de Folin, 1870 and Auristomia Monterosato, 1884 used as genera or subgenera (Lozouet et al. 2001; Høisæter 2014).

\section{Brachystomia sp.}

(Fig. 8B1, B2)

Material eXamined. - Sample F11: AMPG(IV) 2570-2572 (three specimens)

Dimensions. - Maximum height: $2.00 \mathrm{~mm}$.

Distribution. — Early Miocene. Proto-Mediterranean Sea: Greece (this paper).

\section{DESCRIPTION}

Moderately slender shell with apical angle of $c .25^{\circ}$. Intorted type $C$ protoconch of $c .210 \mu \mathrm{m}$ diameter. Teleoconch consisting of five weakly convex smooth whorls; suture non-canaliculate impressed. Last whorl attains $60 \%$ of total height with faint angulation; base moderately convex, slowly contracting. Narrow ovate aperture; columella with small fold not visible in direct apertural view. Umbilicus reduced to barrow chink.

\section{REMARKS}

The apex appears blunt due to the completely intorted protoconch which is a character separating the genera Brachystomia Monterosato, 1884 and Odostomia Fleming, 1813 (Robba 2013; Landau \& LaFollette 2015). Furthermore, the shell is smooth and the protoconch very flat which are characters shared with the type species of the genus B. scalaris MacGuillivray, 1843 as described and illustrated by Høisæter (2014). Based on the similarities 


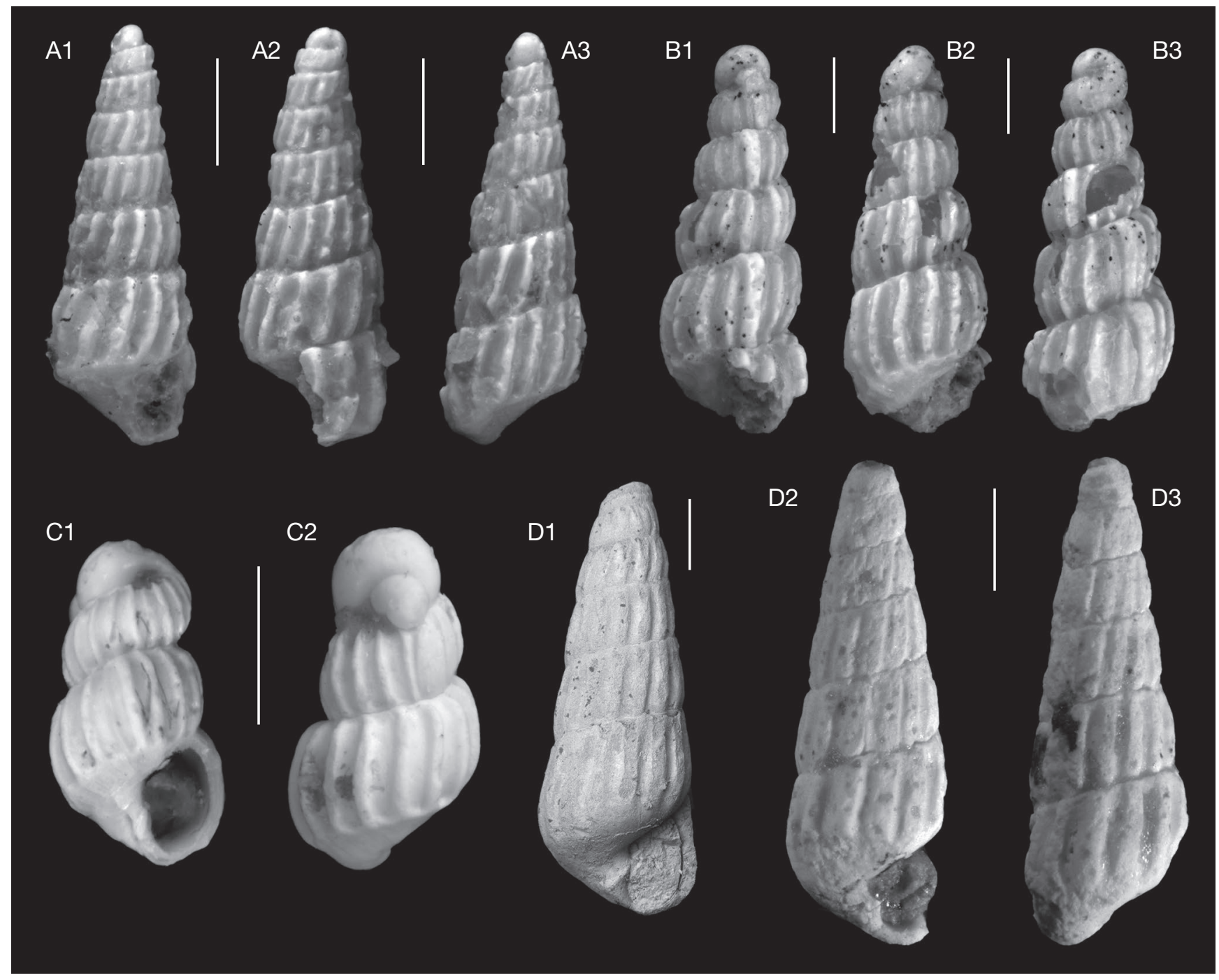

Fig. 9. - A1-A3, Turbonilla (s.l.) sp. 1, AMPG(IV) 2580; B1-B3, Turbonilla (s.l.) sp. 2, AMPG(IV) 2583; C1, C2, Turbonilla (s.l.) sp. 3, AMPG(IV) 2584; D1-D3, Turbonilla (s.l.) sp. 4: D1, AMPG(IV) 2586 (SEM image); D2, D3, AMPG(IV) 2687. Scale bars: 500 нm.

The shape of the Greek shells share the basic characters of the genus Brachystomia Monterosato, 1884 Odostomia (Brachystomia) sp. from the Miocene of the North Sea Basin (Moths et al. 2010). It has an intorted protoconch, a smooth shell, and similar aperture with a narrow umbilical chink and a columellar tooth not clearly visible in direct apertural view. Nevertheless, the latter specimen has a less blunt apex and is slightly longer (maximum height: $2.40 \mathrm{~mm}$ ) than the Greek specimen. The general aspect and morphology is also close to Odostomia fusulus Monterosato, 1878 (Landau et al. 2013) (= Auristomia fusulus (Monterosato, 1878)), including the structure of the protoconch, but it is narrower and has a smaller aperture. Odostomia elisabethae Boettger, 1907 from the Serravallian of the Karaman Basin (Turkey) is another morphologically close species with a less intorted protoconch, clearly defined umbilicus, much more prominent umbilical fold, and smaller aperture than the Greek specimen. Lastly, the overall morphology is close to Ondina cicatricosa Lozouet, Lesport \& Renard, 2001, especially regarding the apex and the proportion of the last whorl, the main differences with the Greek specimen are the opisthocline growth lines, the inconspicuous spiral sculpture which is absent from Brachystomia sp., and the deep umbilicus.

\section{Genus Pyramistomia Cossmann, 1921}

TYPE SPECIES. — Odostomia deubeli Boettger, 1902, by monotypy. Middle Miocene of Romania.

Pyramistomia aliakmoni n. sp. (Fig. 8E1-E4)

urn:Isid:zoobank.org:pub:A2760279-BE3E-4730-9688-9AB777F3A357

TyPe MATERIAL. - Holotype: sample F11: AMPG(IV) 1500. Paratype 1: sample F11: AMPG(IV) 1501. — Paratype 2: sample F11: AMPG(IV) 1502. 
DimENSIONS. - Maximum height: $1.95 \mathrm{~mm}$; maximum width: $1.00 \mathrm{~mm}$.

EтyмоLogy. - Named after the river god Aliakmon of Greek mythology (son of Oceanus and Tethys), who lived in the river Aliakmon where the specimen was collected.

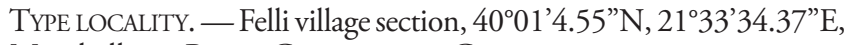
Mesohellenic Basin, Grevena area, Greece.

Type LeVel. - Pentalofos Formation, Aquitanian, lower Miocene.

DiagnOSIs. - Small-sized species of Pyramistomia with pyramidal shape, type $\mathrm{C}$ inverted protoconch, smooth whorls, canaliculated suture with distinct axial threads, and single, prominent spiral cord at abapical suture.

Distribution. — Early Miocene. Proto-Mediterranean Sea: Greece (this paper)

\section{DESCRIPTION}

Small solid pyramidal shell, apex blunt. Protoconch of type C, completely intorted. Teleoconch of 4-4.5 whorls. Suture canaliculated, impressed with distinct axial threads. Prominent spiral cord at abapical suture. Axial sculpture of inconspicuous strongly prosocline irregularly spaced growth lines; spiral threads on base. Columella thickened, with small tooth, bordering a narrow umbilical chink.

\section{REMARKS}

This species is set apart from other members of the family by its solid shell, its type $\mathrm{C}$ protoconch, and its strong spiral sculpture that consists of a prominent suprasutural spiral cord. Few species of Pyramistomia have been described in the fossil record and recent species are also scarce (Landau et al. 2013). Pyramistomia deubeli (Boettger, 1902) is a relatively well-known species from the middle Miocene of Europe (Paratethys, Proto-Mediterranean Sea). It differs from P. aliakmoni n. sp. in its additional spiral cord below the adapical suture and the broader outline. Recent species of Pyramistomia described by Peñas \& Rolán (1999) and discussed by Landau et al. (2013) seem to belong to the genus Odostomia, and the placement in a particular genus is uncertain. The recent Odostomia fehrae Van Aartsen, Gittenberger \& Goud, 1998, placed in Pyramistomia by van Aartsen et al. (1998), might rather be related with Eulimastoma according to Pimenta \& Absalâo (2004).

\section{Genus Parthenina \\ Bucquoy, Dautzenberg \& Dollfus, 1883}

TYPE SPECIES. - Turbo interstinctus J. Adams, 1797 (= Parthenina interstincta (J. Adams, 1797)), by original designation.

\section{REMARK}

This genus was used by Peñas \& Rolán (2017) for recent deep water Pyramidelloidea from the Central and South Pacific. These authors assumed that the Indo-Pacific species should be placed in Prestoniella Saurin, 1958. Here, the European species of the Early Miocene of the Proto-Mediterranean are considered to belong to Parthenina as suggested by Landau et al. (2013).

\section{Parthenina sp. 1}

(Fig. 8F1-F4)

Material examined. - Sample F11: AMPG(IV) 2573, 2574 (two specimens).

Dimensions. - Maximum height: $1.00 \mathrm{~mm}$.

Distribution. - Early Miocene. Proto-Mediterranean Sea: Greece (this paper).

\section{DESCRIPTION}

Minute shell; type C protoconch. Two teleoconch spires preserved; axial sculpture consists of slightly sigmoidal and regularly spaced orthocline smooth ribs; spiral sculpture consists of flat spiral cords. Abapically, the cords overlap with the ribs. Aperture tear-shaped; strong columellar fold.

\section{REMARKS}

The sculpture and type $\mathrm{C}$ protoconch are similar to Chrysallida longula (Boettger, 1907) from the middle Miocene of the Paratethys and the Proto-Mediterranean (Landau et al. 2013).

Parthenina longula (Boettger, 1907) differs from the Greek shell in its much more prominent axial ribs, the less convex first teleoconch whorl and the absence of the weak sutural cord. The weak sutural cord around the upper suture also allows a separation of this species from Parthenina amaciata (Nrusina, 1966), P. majae Landau, Harzhauser, İslamoğlu \& Da Silva, 2013 and P. obtusa (Brown, 1827) as described by Landau et al. (2013) for the Serravallian (Middle Miocene) of Turkey. Furthermore, the sculpture of the shell is reminiscent of Parthenina belgica Glibert, 1958 (e.g. in Moths et al. 2010), with this species having a more elongated shell. It also differs from Parthenina pygmaea (Grateloup, 1838) in having a finer spiral sculpture.

\section{Parthenina sp. 2}

(Fig. 8G1, G2)

Material EXAmined. — Sample F11: AMPG(IV) 2575, 2576 (two incomplete specimens).

Dimensions. — Maximum height: $1.18 \mathrm{~mm}$

Distribution. - Early Miocene. Proto-Mediterranean Sea: Greece (this paper).

\section{DESCRIPTION}

Elongated pupoid small shell; type C smooth protoconch. Apex blunt; first teleoconch whorl flat. Three teleoconch whorls preserved, whorls 2 and 3 almost flat; axial sculpture consists of slightly sigmoidal and opisthocline rounded ribs; spiral sculpture includes one abapical cord present between ribs. Sutures deep, V-shaped. Narrow umbilicus; columellar tooth present; aperture missing. 


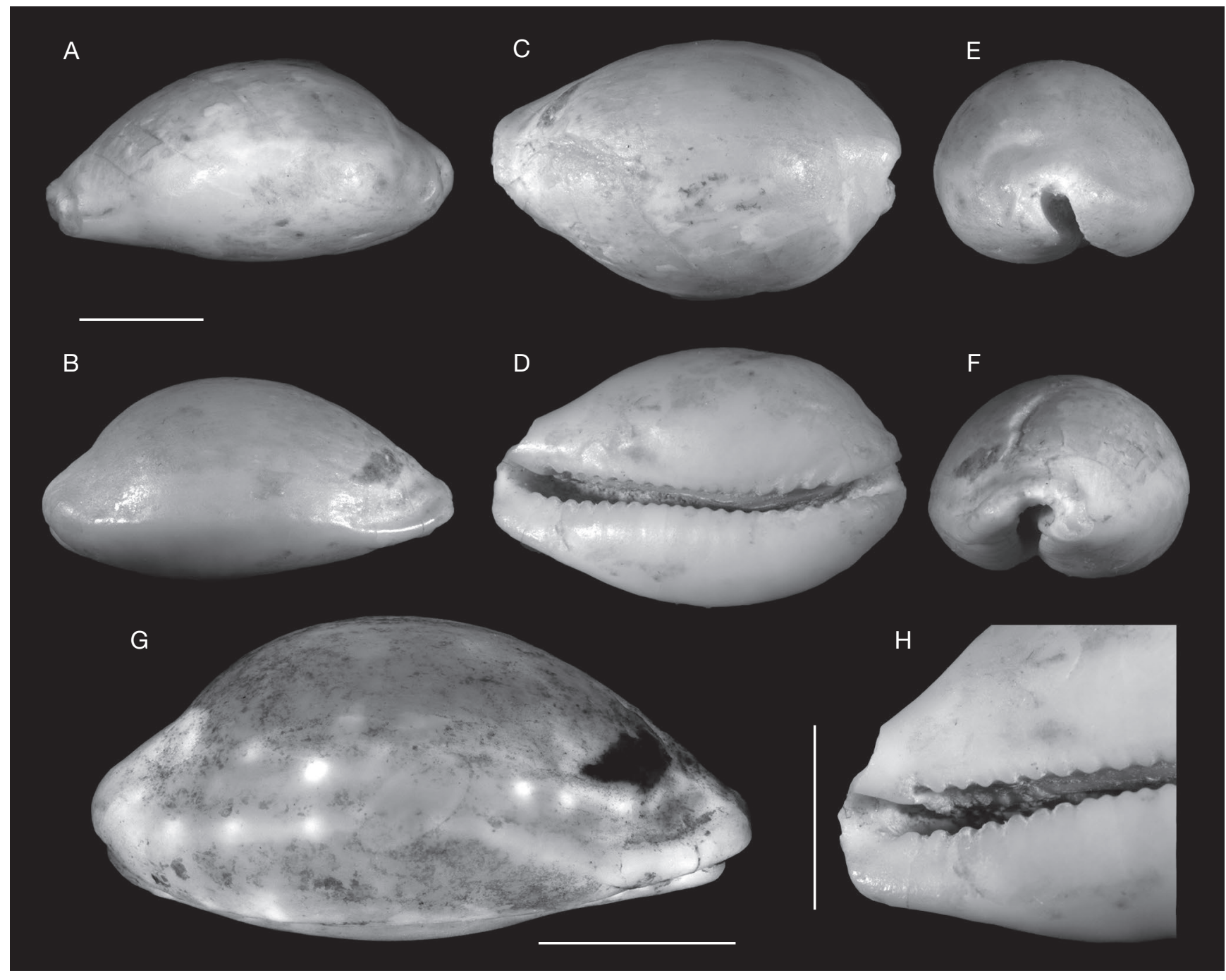

FIG. 10. - ?Praerosaria sp.: A-H, AMPG(IV) 2460; G, AMPG(IV) 2460, under UV light. Scale bars: 5 mm.

\section{REMARKS}

The present shell is morphologically very close to Parthenina obtusa (Brown, 1817) as illustrated by Landau et al. (2013). Nevertheless, the Greek species differs in having a marked angulation close above the lower suture from the first teleoconch whorl on, and steeper flanks. In the stratotype region of the Aquitanian (SW France), Parthenina degrangei (Cossmann \& Peyrot, 1917) has a similar axial sculpture (Lozouet et al. 2001) that becomes more strongly opisthocline on the last whorl, and bear two spiral cords above the lower suture on the two last teleoconch whorls whereas the Greek species only has one.

Subfamily SyRNOLINAE Saurin, 1958

Genus Syrnola A. Adams, 1860

TYPE SPECIES. - Syrnola gracillima A. Adams, 1860, by monotypy. Recent (Holocene), Japan.
REMARK

According to van Aartsen et al. (2000), Syrnola members have a clearly defined columellar tooth.

?Syrnola sp.

(Fig. 8H)

Material eXAmined. - Sample F11: AMPG(IV) 2577-2579 (three specimens).

Dimensions. - Maximum height: $1.83 \mathrm{~mm}$

Distribution. — Early Miocene. Proto-Mediterranean Sea: Greece (this paper).

\section{REMARKS}

The specimens are placed only tentatively in this genus since the protoconch is weathered, and could possibly be of type A2; the columella bears a clearly defined tooth as in Syrnola species (van Aartsen et al. 2000). The overall morphology 
of the shell is very similar with the Eocene species Syrnola polygyrata (Deshayes, 1861), with the later species having a type A1 protoconch.

\section{Subfamily TurbonillinaE Bronn, 1849}

\section{Genus Turbonilla Risso, 1826}

TYPE SPECIES. - Turbonilla costulata Risso, 1826 (= Turbonilla lactea (Linnaeus, 1758)), subsequent designation by Hermannsen (1852). Pleistocene, France.

\section{REMARK}

The genus Turbonilla is characterized by species with elongated and ornate shells, and type A helicoidal protoconchs (Peńas \& Rolán 2010). As shown by Schander et al. (2003) relationships within some major gastropod clades have still not been studied. The Pyramidellidae is one such group, comprising more than 6000 named species in more than 350 genera. We sequenced part of the mitochondrial 16S gene from 32 species in an attempt to clarify pyramidellid phylogeny and employed a successive alignment approach that allowed us to maximize the phylogenetic signal of the data. Neighbour-joining, maximum parsimony and likelihood analyses recovered two distinct clades. One clade consisted of Noemiamea which nested within Odostomia (sensu stricto, the subfamily Turbonillinae Bronn, 1849 is polyphyletic. In the work by Landau \& LaFollette (2015) on Miocene deposits of Venezuela it was possible to differenciate between Chemnitzia d'Orbigny 1840 and Turbonilla s.s. Risso, 1826. Herein, we use Turbonilla s.l. since the preservation of the shells does not allow a certain generic attribution or identification to the species level.

\section{Turbonilla s.l. sp. 1}

(Fig. 9A1-A3)

Material eXAmined. — Sample F11: AMPG(IV) 2580-2582 (three specimens).

DimENSIONS. - Maximum height: $2.15 \mathrm{~mm}$ (incomplete), diameter: $0.65 \mathrm{~mm}$.

Distribution. - Early Miocene. Proto-Mediterranean Sea: Greece (this paper).

\section{DESCRIPTION}

Type A2 helicoidal protoconch forming an angle of $115^{\circ}$ with the axis of the shell; diameter: $195 \mu \mathrm{m}$. Largest available fragmentary specimen consisting of six flat teleoconch whorls forming moderately slender shell of $c .22^{\circ}$; sculpture consisting of opisthocline convex equally-spaced ribs numbering 6 on last preserved whorl, separated by concave interspaces of roughly same width. Axial ribs terminating as distinct tips at adapical suture (not fading out) and passing into weak spiral cord at transition into base on last preserved whorl. No spiral sculpture. Sutures linear and impressed; no columellar fold; aperture missing.

\section{REMARKS}

The present species shares many morphological similarities with Turbonilla spiculoides Cossmann \& Peyrot, 1917 from the Early Miocene of France (Aquitaine) as far as the sculpture is concerned. The protoconch is very similar in terms of size for the Greek species and T. spiculoides. The main difference is that $T$. spiculoides has more rounded ribs and the space between the ribs is shallower. Moreover, its teleoconch whorls are slightly convex (Cossmann \& Peyrot 1917; Lozouet et al. 2001). Other similar species are T. gastaldi (Semper, 1865) and T. superstructa Boettger, 1907, which present similar sculptures but can be less slender and have more convex whorls.

\section{Turbonilla s.l. sp. 2}

(Fig. 9B1-B3)

Material eXamined. - Sample F11: AMPG(IV) 2583 (one specimen).

Dimensions. - Maximum height: $2.58 \mathrm{~mm}$ (incomplete), diameter: $1.00 \mathrm{~mm}$.

Distribution. — Early Miocene. Proto-Mediterranean Sea: Greece (this paper).

\section{DESCRIPTION}

Type A2 helicoidal protoconch of three whorls forming angle of $125^{\circ}$ relative to shell axis; diameter: $360 \mu \mathrm{m}$. Last whorl disproportionately larger than the first two. Fragmentary teleoconch consisting of 4.5 convex whorls with incised suture; spire angle about $20^{\circ}$. Sculpture consisting of blunt, faintly opisthocline to sigmoidal axial ribs with convex tops. Spacing slightly irregular with smooth, moderately deep interspaces. Each whorl bears two varix-like axial ribs; first and second one placed under the tip of the protoconch and on opposite side. No spiral sculpture. Aperture missing.

\section{REMARKS}

This species of Turbonilla is characterized by its convex whorls, the prominent sculpture with two varix-like axial ribs per whorl and the allometric growth of the last protoconch whorl.

Turbonilla koeneniana Sacco, 1892 as figured by A.W. Janssen (1984) from the Miocene of the Netherlands is a closely similar species, which differs by having more convex whorls, a slightly more conical shape and randomly placed varices of variable width. Nevertheless, the protoconch has a similar structure with a very inflated last whorl. The different varieties of T. pseudocostellata with prominent costae presented by Sacco (1892) differ from the present specimen by having more rounded ribs, no varices, more slender shape, less prominent protoconch and less impressed sutures.

\section{Turbonilla s.l. sp. 3}

(Fig. 9C1, C2)

Material eXamined. - Sample F11: AMPG(IV) 2584-2585 (two specimens). 


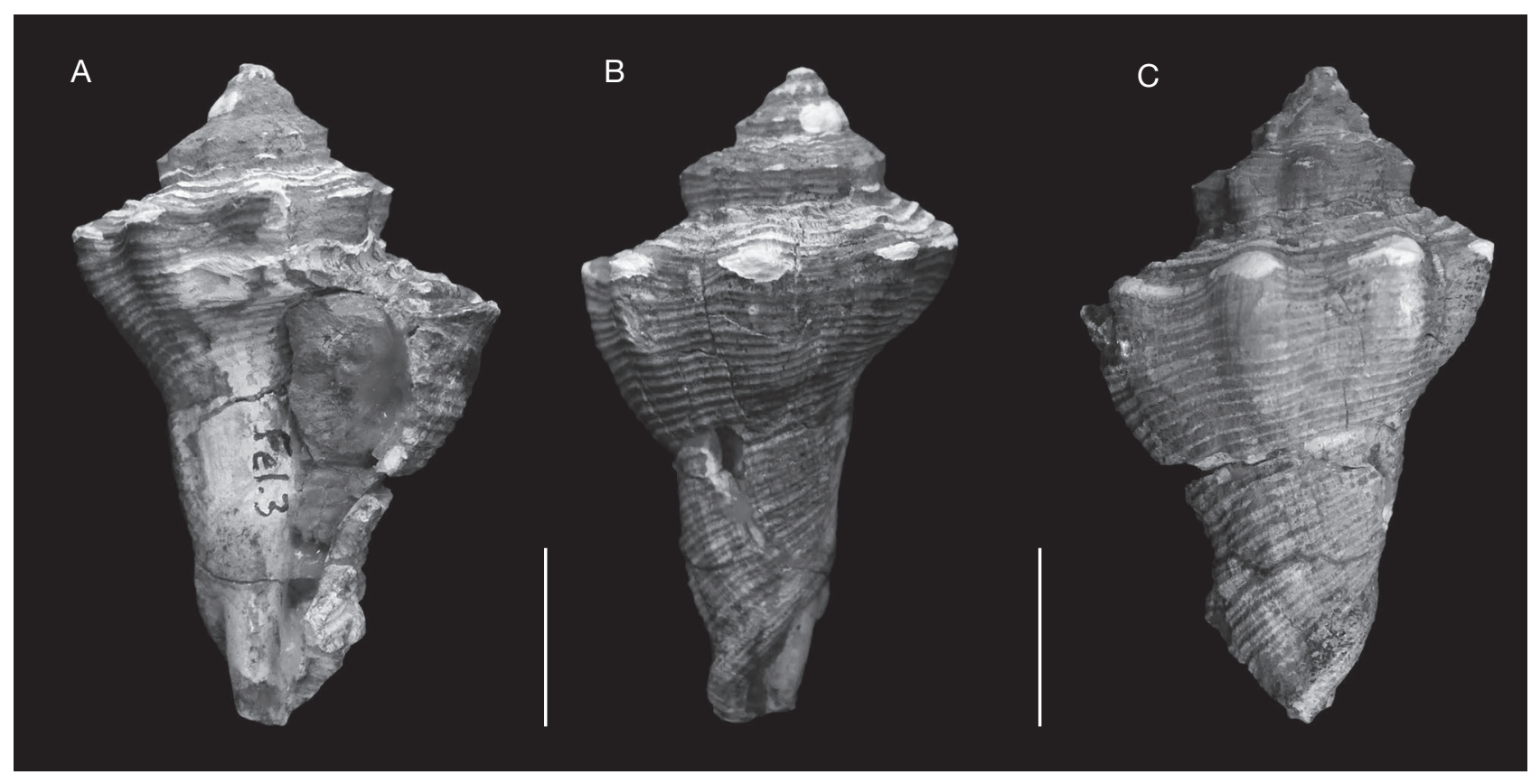

FIG. 11. - Melongena lainei (de Basterot, 1825), AMPG(IV) 2467. Scale bars: $10 \mathrm{~mm}$.

\section{Dimensions. — Maximum height: $1.25 \mathrm{~mm}$}

Distribution. - Early Miocene. Proto-Mediterranean in Greece (this paper).

\section{DESCRIPTION}

Type A2 helicoidal protoconch; four convex teleoconch whorls preserved. Protoconch forms an angle of about $105^{\circ}$ with the axis of the shell. Teleoconch sculpture consists of closely and regularly spaced prosocline fine axial ribs. Inconspicuous columellar fold; aperture missing.

\section{REMARKS}

A third species of Turbonilla is present. The sculpture is reminiscent of Turbonilla sp. 1, but the axial ribs are less prominent, more rounded and more closely spaced; the whorls are also more convex.

\section{Turbonilla s.l.sp. 4}

(Fig. 9D1-D3)

MATERIAl EXAMINED. — Sample F11: AMPG(IV) 2586-2593 (eight incomplete specimens).

Dimensions. - Maximum height: $1.85 \mathrm{~mm}$; maximum width: $0.75 \mathrm{~mm}$.

Distribution. - Early Miocene. Proto-Mediterranean Sea: Greece (this paper).

\section{DESCRIPTION}

Elongated, turreted shell, apex missing. Longest teleoconch recovered bears six almost flat whorls; sutures linear, faintly impressed; axial sculpture consists of 6-7 flat almost orthocline ribs, spaces between ribs are smooth. Base smooth; aperture sub-rectangular, columellar fold moderately developed, outer lip straight.

\section{REMARKS}

This is the largest species of Turbonilla, with a maximum width of $0.75 \mathrm{~mm}$; all of the shells recovered are incomplete. Some type A protoconchs recovered could be attributed to this species although not with certainty (incomplete specimens with only one teleoconch whorl). The ribs have a curved and opisthocline structure (not sigmoidal) which is more prominent in the first teleoconch whorls.

Since the present material is incomplete it cannot be attributed with certainty to a species, although it shares many similarities with T. (Turbonilla) gastaldi auct. (non Semper, 1861) (A.W. Janssen 1984; Landau et al. 2013) in terms of sculpture and shape of the aperture. It differs from T. spiculoides in having less inflated whorls and a flatter axial sculpture. Turbonilla cf. superstructa Boettger, 1907 from the Serravallian of Turkey (Landau et al. 2013) has a comparably elongated shell yet with more convex whorls.

\section{Acknowledgements}

This research was supported by SYNTHESYS project FRTAF-6608. Valuable comments were provided by Dr Pierre Lozouet (Muséum national d'Histoire naturelle, Paris) and Luc Dolin (Civray-de-Touraine, France). Special thanks to Mr Nikos Baharidis for suggesting sampling locations. The authors are grateful to Dr Andreas Kroh (Natural History Museum Vienna) and Dr Paolo G. Albano (University of Vienna) for acquisition of SEM photographs; Lilian Cazes (Muséum national d'Histoire naturelle, Paris) for acquisition of UV photographs. Finally, we thank Bernard M. Landau and Stefano Dominici for their constructive comments that helped improve the quality of the manuscript.

This work is part of the Ph.D. thesis of Danae Thivaiou, P.I. Efterpi Koskeridou. 


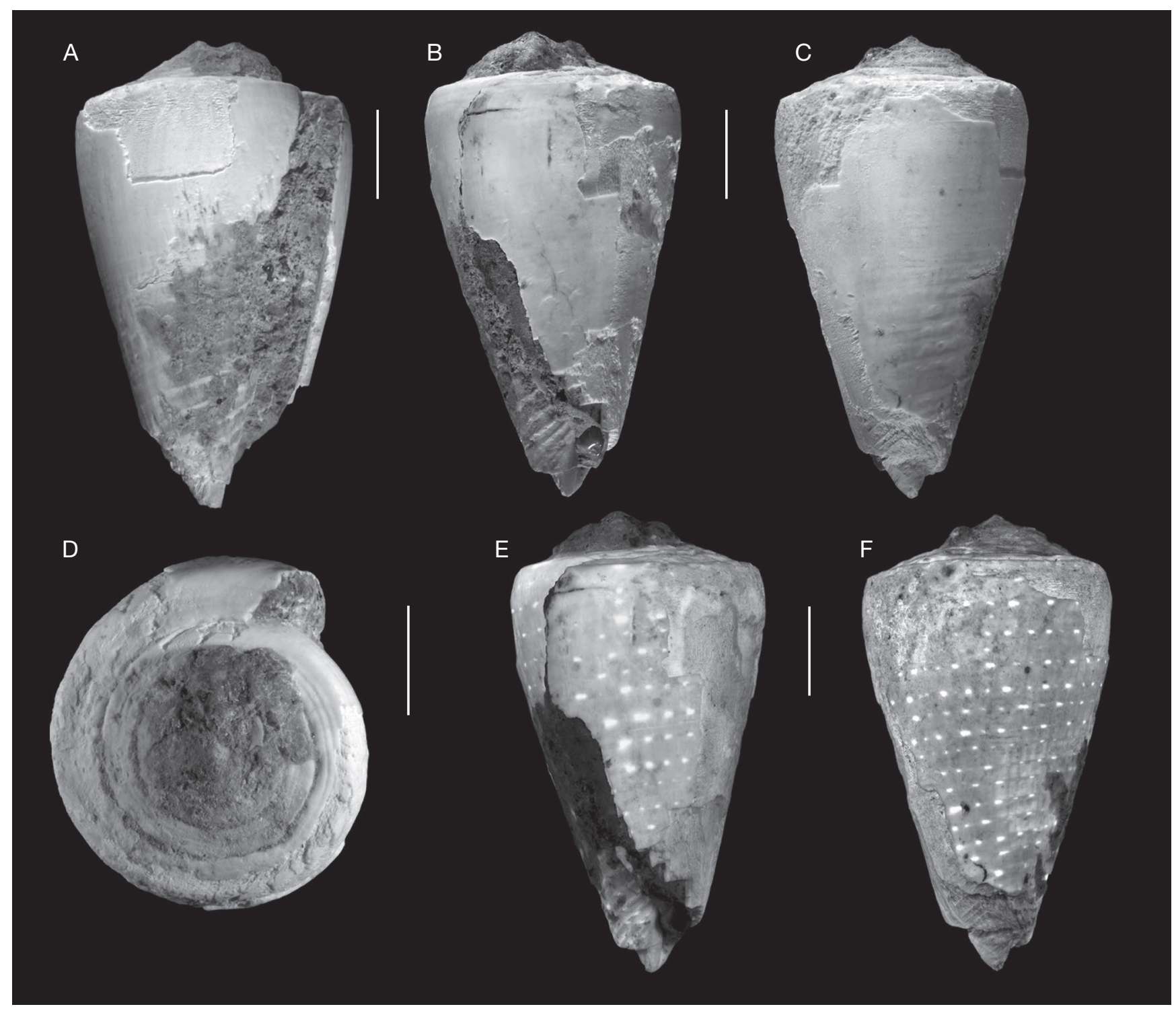

FIG. 12. - ?Lautoconus. sp.: A-D, AMPG(IV) 2473; E, F, AMPG(IV) 2473, under UV light. Scale bars: 5 mm.

\section{REFERENCES}

Aartsen J. J. van, Gittenberger E. \& Goud J. 1998. — Pyramidellidae (Mollusca, Gastropoda, Heterobranchia) collected during the Dutch CANCAP and MAURITANIA expeditions in the south-eastern part of the North Atlantic Ocean (part 1). Zoologische verhandelingen/uitgegeven door het Rijksmuseum van Natuurlijke Historie te Leiden: 1-57.

Aartsen J. J. van, Gittenberger E. \& Goud J. 2000. — Pyramidellidae (Mollusca, Gastropoda, Heterobranchia) collected during the Dutch CANCAP and MAURITANIA expeditions in the south-eastern part of the North Atlantic Ocean, 2. Zoologische Mededelingen 74: 1-50. http://www.repository.naturalis. nl/document/44074

ADAMS A. 1862. — On some new species of Cylichnidae, Bullidae and Philinidae from the seas of China and Japan. Annals and Magazine of Natural History (3) 9: 150-161. https://biodiversitylibrary.org/page/27257494

Allmon W. D. 2011. — Natural History of Turritelline Gastropods (Cerithiodea: Turritellidae): A Status Report. Malacologia 54: 159-202. https://doi.org/10.4002/040.054.0107
Baker H. B. 1923. - Notes on the Radula of the Neritidae. Proceedings of the Academy of Natural Sciences of Philadelphia 75: 117-178. https://www.jstor.org/stable/pdf/4063879.pdf

BÁLDI T. 1973. - Mollusc Fauna of the Hungarian Upper Oligocene (Egerian); Studies in Stratigraphy, Palaeoecology, Palaeogeography and Systematics. Akadémiai Kiadó, Budapest, 511 p.

BAŁUK W. 1970. - The Lower Tortonian at Niskowa near Nowy Sacz, Polish Carpathians. Acta Geologica Polonica 20: 101-157.

BAŁUK W. 1975. — Lower Tortonian Gastropods from Korytnica, Poland 1. Paleontologia Polonica 32: 1-186.

BAŁUK W. 1995. — Middle Miocene (Badenian) gastropods from Korytnica, Poland; Part II. Acta Palaeontologica Polonica 45 (3-4): 153-255.

BAŁUK W. 1997. — Middle Miocene (Badenian) gastropods from Korytnica, Poland, Part III. Acta Geologica Polonica 45 (3-4): 153-255.

BANDEL K. \& KowAlKE T. 1999. - Gastropod fauna of the Cameroonian coasts. Helgoland Marine Research 53: 129-140. https:// doi.org/10.1007/s101520050016

BASTEROT B. DE 1825. - Description géologique du Bassin tertiaire du Sud-Ouest de la France. Mémoires de la Société d'Histoire naturelle de Paris 2 (2): 1-100. https://biodiversitylibrary.org/ page/3591528 
Berger W. 1953. - Die Bullacean aus dem Tertiär des Wiener Beckens. Archiv für Molluskenkunde 82: 81-129.

BITLIS B. \& ÖZTÜRK B. 2017. — The genus Alvania (Gastropoda: Rissoidae) along the Turkish Aegean cost with the description of a new species. Scientia Marina 81 (3): 395-411. https://doi. org/10.3989/scimar.04566.14A

BoetTGer O. 1902. — Zur Kenntnis der Fauna der mittelmiocänen Schichten von Kostej im Krassó-Szörényer Komitat. Mit einem Situationsplan der Fundpunket, 2. Verhandlungen und Mitteilungen des Siebenbürgischen Vereins für Naturwissenschaften zu Hermannstadt 51 (1901): 1-200. https://biodiversitylibrary.org/page/35260319

Bogi C. \& Cuneo F. 1999. - Il genere Odostomia in Mediterraneo. Documenti del Gruppo Malacologico Livornese, published in February.

Bouchet P. 1985. — Les Triphoridae de Mediterranee et du proche Atlantique (Mollusca, Gastropoda). Lavori della Società Italiana Malacologica 21: 5-58.

Bouchet P., Gofas S. \& Warén A. 2010. - Notes on Mediterranean Dizoniopsis (Gastropoda: Cerithiopsidae), with the description of two new species. Iberus 28 (2): 51-62. https:// biodiversitylibrary.org/page/50447277

Bouchet P., Rocroi J.-P., Hausdorf B., Kaim A., Kano Y., NÜtZel A., ParkHaev P., SChrödl \& Strong E. 2017. — Revised Classification, Nomenclator and Typification of Gastropod and Monoplacophoran Families. Malacologia 61 (1-2): 1-526. https:// doi.org/10.4002/040.061.0201

BOURY E. DE 1883. - Description d'espèces nouvelles de Mathilda du Bassin de Paris, et révision du genre. Journal de Conchyliologie 31: 110-153. https://biodiversitylibrary.org/page/15857125

Brocchi G. 1814. - Conchiologia fossile subapennina, con osservazioni geologiche sugli Apennini e sul suolo adiacente 1. Stamperia Reale, Milano: 1-240. https://biodiversitylibrary.org/page/12001699

Bronn H. G. 1838. - Lethaea Geognostica, oder Abbildung und Beschreibung der für die Gebirgsformationen bezeichnendsten Versteinerungen. Zweiter Band, das Keride- und Molassen-Gebirge enthaltend. E. Schweizerbart, Stuttgart: 545-1346.

BRUGUitere J. G. 1792. - Encyclopédie méthodique ou par ordre de matières. Histoire naturelle des vers. Panckoucke, Paris, vol. 1: 345-757. https://doi.org/10.5962/bhl.title.8638

Burn P. \& Thompson T. E. 1998. - Order Cephalaspidea, in Beesley P. L., Ross G. J. B. \& Wells A. (eds), Mollusca: the Southern Synthesys. Fauna of Australia. Vol. 5, Part B. CSIRO Publishing, Melbourne: viii, 565-1147.

BÜYÜKMERIÇ Y. 2017. — Molluscan biostratigraphy of early Miocene deposits of the Kale-Tavas and Acipayam basins (Denizli, SW Turkey). Bulletin of the Mineral Research and Exploration 155: 49-73. https://doi.org/10.19111/bulletinofmre.305166

Cahuzac B., Cluzaud A. \& Lesport J. F. 2012. — Les faunes de mollusques de divers affleurements stratotypiques de l'Aquitanien du vallon du Saucats entre La Brède et Bernachon (SW France) inventaire et paleoecology. Bulletin de la Société linéenne de Bordeaux 40 (4): 369-415.

Cerulli-Irelli S. 1910. - Fauna malacologica mariana, 4 (Dentaliidae), Stenogyridae, Gadiniidae, Actaeonidae, Tornatinidae, Scaphandridae, Bullidae, Ringiculidae, Philinidae, Umbrellidae, Conidae, Pleurotomidae. Paleontographica Italica 16: 215-262.

Cerulli-Irelli S. 1914. - Fauna malacologica mariana, 7. Melaniidae, Fossaridae, Solariidae, Rissoidae, Capulidae, Calyptraeidae, Xenophoridae, Lamellariidae, Naticidae, Scalidae, Aclisidae, Eulimidae, Pyramidellidae. Paleontographia Italica 20:357-451.

Chaban E. M., Kano Y., Fukumori H. \& Chernyshev A. V. 2017. - Deep-sea gastropods of the family Ringiculidae (Gastropoda, Heterobranchia) from the Sea of Okhotsk, KurilKamchatka Trench, and adjacent waters with the description of three new species. Deep-Sea Research Part II: 1-17. https://doi. org/10.1016/j.dsr2.2017.11.008

ChirLi C. 2013. - Malacofauna Pliocenica Toscana, 9. Gastropoda fine Scaphopoda. C. Chirli, Firenze, 169 p.
Cluzaud A., Lesport J.-F., Cahuzac B. \& Janssen A. 2014. Mollusques, in LondeIX L. (ed.), Stratotype Aquitanien. Muséum national d'Histoire naturelle, Paris and Biotope, Mèze: 223-232 (Patrimoine géologique; 5).

Cossmann M. 1906. - Essais de Paléoconchologie comparée. Livraison 7. Chez l'auteur, Paris, 261 p. https://biodiversitylibrary. org/page/36852315

Cossmann M. 1921. - Essais de Paléoconchologie comparée. Livraison 12. Chez l'auteur, Paris , 349 p. https://biodiversitylibrary. org/page/37199123

COSSMANN M. \& PEYROT A. 1917. - Conchologie néogènique de l'Aquitaine. Actes de la Société linnéenne de Bordeaux 69: 157-365. https://biodiversitylibrary.org/page/31657755

Cossmann M. \& PeYrot A. 1919. - Conchologie néogènique de l'Aquitaine. Édition in-8o. Extraits des Actes de la Société linnéenne de Bordeaux 3 (2): 385-695.

Cossmann M. \& PeYrot A. 1921. - Conchologie néogènique de l'Aquitaine. Actes de la Société linnéenne de Bordeaux 73: 5-321. https://biodiversitylibrary.org/page/31662049

Cossmann M. \& Peyrot A. 1922. - Conchologie néogènique de l'Aquitaine. Édition in-80. Extraits des Actes de la Société Linnéenne de Bordeaux 4 (1): 1-322.

Criscione F. \& PONDER W. 2012. - A phylogenetic analysis of rissooidean and cingulopsoidean families (Gastropoda: Caenogastropoda). Molecular Phylogenetics and Evolution 66 (3): 1075 1082. https://doi.org/ 10.1016/j.ympev.2012.11.026

Crosse H. 1885. - Nomenclatura generica e specifica di alcune Conchiglie Mediterranee, pel marchese di Monterosato. Journal de Conchyliologie 33: 139-142. https://biodiversitylibrary.org/page/15979493

Cunha R. L., Grande C. \& Zardoya R. 2009. - Neogastropod phylogenetic relationships based on entire mitochondrial genomes. BioMed Central Evolutionary Biology 9: 210. http:// doi.org/10.1186/1471-2148-9-210

DERMITZAKIS M. 1972. - Bio-statistical observations on the Terebralia lignitarum (Eichwald) from the Miocene of East Crete. Annales géologiques des Pays helléniques 24: 481-514 (in Greek).

Di Geronimo I., Allegri L., Improta S., La Perna R., Rosso A. \& SANFILIPPO R. 1997. - Spatial and temporal aspects of benthic thanatocoenoses in a mediterranean infralittoral cave. Rivista Italiana di Paleontologia e Stratigrafia 103 (1): 15-28. https://doi.org/10.13130/2039-4942/5277

Dinapoli A., Zinssmeister C. \& KLUSSMANN-Kolb A. 2011. New insights into the phylogeny of the Pyramidellidae (Gastropoda). Journal of Molluscan Studies 77 (1): 1-7. https://doi. org/10.1093/mollus/eyq027

DingenEn F. van, Ceulemans L. \& Landau B. M. 2016. - The lower Pliocene gastropods of Le Pigeon Blanc (Loire-Atlantique, north west France), 2. Caenogastropoda. Cainozoic Research 16 (2): 109-219.

Dolin L. \& LozOuET P. 2004. — Nouvelles espèces de Gastéropodes (Mollusca: Gastropoda) de l'Oligocène et du Miocène inférieur de l'Aquitaine (Sud-Ouest de la France). Partie 3. Cypraeidae et Ovulidae. Cossmanniana HS 4: 7-164.

EICHWALD E. 1830. - Naturhistorische Skizze von Lithauen, Volhynien und Podolien in geognostisch-mineralogischer, botanischer und zoologischer Hinsicht. Eichwald, Wilna, 256 p.

Esu D. \& GirotTi O. 2010. - The late Oligocene molluscan fauna from Otranto (Apulia, Southern Italy): An example of alternating freshwater, lagoonal and emerged environments. Palaeontology 53 (1): 137-174. https://doi.org/10.1111/j.1475-4983.2009.00923.x

Fedosov A., Puillandre N., Kantor Y. \& Bouchet P. 2015. Phylogeny and systematics of mitriform gastropods (Mollusca: Gastropoda: Neogastropoda). Zoological Journal of the Linnean Society 175 (2): 336-359. https://doi.org/ 10.1111/zoj.12278

Fedosov A., Puillandre N., Herrmann M., Dgebuadze P. \& BOUCHET P. 2017. - Phylogeny, systematics, and evolution of the family Costellariidae (Gastropoda: Neogastropoda). Zoological Journal of the Linnean Society 179 (3): 541-626. https://doi. org/10.1111/zoj.12431 
Ferrière J., Reynaud J.-Y., Pavlopoulos A., Bonneau M., Migiros G., Chanier F., Proust J.-N. \& Gardin S. 2004. Geologic evolution and geodynamic controls of the Tertiary intramontane piggyback Meso-Hellenic basin, Greece. Bulletin de la Société géologique de France 175: 361-381. https://doi. org/10.2113/175.4.361

Férussac J. B. L. D’Audebard De \& Deshayes G. P. 1823. Histoire naturelle générale et particulière des mollusques terrestres et fluviatiles, tant espèces que l'on trouve aujourd'hui vivantes, que des dépouilles fossils de celles qui n'existent plus; classés d'après les caractères essentiels que presentment ces animaux et leurs coquilles, livraison 20. Nérites fossiles. Paris (J.-B. Baillère): pl. 2. https:// doi.org/10.5962/bhl.title.124603

FriedberG W. 1914. - Mieczaki mioceńskie ziem Polskich (Mollusca Miocaenica Poloniae), 1. Ślimaki i łódkonogi, 1. Gastropoda et Scaphopoda. Muzeum Imienia Dzieduszyckich, Lwow 3: 241 360. http://fbc.pionier.net.pl/id/oai:rcin.org.pl:29894

Galindo L. A., Puillandre N., Utge J., Lozouet P. \& Bouchet P. 2016. - The phylogeny and systematics of the Nassariidae revisited (Gastropoda, Buccinoidea). Molecular Phylogenetics and Evolution 99: 337-353. https://doi.org/10.1016/j.ympev.2016.03.019

Garilli V. \& PARrinello D. 2014. - Taxonomy and Palaeobiogeography of the Cenozoic Euro-Mediterranean rissoid Gastropod Galeodinopsis and its relationship with close genera. Acta Palaeontologica Polonica 59 (2): 379-406. http://www.bioone. org/doi/full/10.4202/app.2012.0044

Georgiades-Dikaioulia E., Kristic N. \& Koskeridou E. 2002. Faunal correlation between the Pliocene of Central Greece (Locride, Megara) and Southern Serbia (Metohia, Kosovo). Bulletin de l'Académie serbe des Sciences et des Arts, Classe des Sciences mathématiques et naturelles, Sciences naturelles 41: 97-120.

Glibert M. 1949. - Gastropodes du Miocène moyen du Bassin de la Loire, 1. Mémoires de l'Institut royal des Sciences naturelles de Belgique 2 (30): 1-240.

GliBerT M. 1952. - Faune malacologique du Miocène de la Belgique, 2. Gastropodes. Mémoires de l'Institut royal des Sciences naturelles de Belgique 129: 1-75.

GLiBERT M. 1958. - Tableau stratigraphique des mollusques du Néogène de la Belgique. Bulletin de l'Institut royal des Sciences naturelles de Belgique 34 (32): 1-20.

Grateloup J. P. S. DE 1827. - Description de plusieurs espèces de coquilles fossiles des environs de Dax (Landes). Bulletin d'Histoire naturelle de la Société linnéenne de Bordeaux 2: 3-27. https:// biodiversitylibrary.org/page/35729870

GraTELOUP J. P. S. DE 1832-34. - Tableau des coquilles fossiles qu'on rencontre dans les terrains calcaire tertiaries (faluns) des environs de Dax, dans le Département des Landes 5 (30): 263-282 (1832); 6 (37): 270-320 (1834).

GrATELOUP J. P. S. DE 1837. - Notice sur la famille des bulléens dont on trouve les dépouilles fossiles dans les terrains marins supérieurs du Bassin de l'Adour, aux environs de Dax (Landes), précédée de considérations générales sur cette famille et du tableau des genres et des espèces connus, soit à l'état vivant soit à l'état fossile. Actes de la Société linnéenne de Bordeaux 9: 365-432. https://biodiversitylibrary.org/page/32867279

Grateloup J. P. S. DE 1838. - Conchyliologie fossile du Bassin de l'Adour (4ème mémoire), famille des mélaniens, appartenant à cette famille de trachélipodes, qu'on observe dans les couches des terrains marins supérieurs du Bassin de l'Ardour, aux environs de Dax (Landes). Actes de la Société linnéenne de Bordeaux 10: 180-214. https://biodiversitylibrary.org/page/32688433

GRATELOUP J. P. S. DE 1845-1847. — Conchyliologie fossile des terrains tertiaire du Bassin de l'Adour (environs de Dax), 1. Univalves. Atlas. Th. Lafargue, Bordeaux: pls 1-45 (1840); i-xx, 12 p.; pls 46-48 (1846). Note: all plates published in 1845, exept plates 2, 4 \& 11 (1847).

GraY J. E. 1847. - A list of the genera of Recent Mollusca, their synonyma and types. Proceedings of the Zoological Society of London: 129-219. https://biodiversitylibrary.org/page/12862913
GRÜNDEL J. \& NÜTZEL 2013. - Evolution and classification of Mesozoic mathildoid gastropods. Acta palaeontologica Polonica 58 (4): 803-826. https://doi.org/10.4202/app.2012.0052

HARZHAUSER M. 2002. - Marine und brachyhaline Gastropoden aus dem Karpatium des Korneuburger Beckens und der Kreuzstettener Bucht (Österreich, Untermiozän). Beiträge zur Paläontologie 27: 61-159.

HARZHAUSER M. 2004. - Oligocene gastropod faunas of the eastern Mediterranean (Mesohellenic Trough/Greece and Esfahan-Sirjan Basin/Central Iran). Courier Forschungsinstitut Senckenberg 248: 93-181.

HaRZHAuser M. 2007. - Oligocene and Aquitanian gastropod faunas from the Sultanate of Oman and their biogeographic implications for the early western Indo-Pacific. Palaeontographica Abteilung A Paläozoologie-Stratigraphie 280: 1-75. https://doi. org $/ 10.1127 / \mathrm{pala} / 280 / 2007 / 1$

Harzhauser M. 2014. - A seagrass-associated Early Miocene Indo-Pacific gastropod fauna from South West India (Kerala). Palaeontographica Abteilung A: Palaozoologie-Stratigraphie 302: 73-177. https://doi.org/10.1127/pala/302/2013/73

HaRZhauser M. \& KowALKe T. 2001. — Early Miocene brackishwater Mollusca from the Eastern Mediterranean and from the central Paratethys - a faunistic and ecological comparison by selected faunas. Journal of the Czech Geological Society 46 (3): 353-374.

Harzhauser M. \& MANDiC O. 2001. — Late Oligocene gastropods and bivalves from the Lower and Upper Austrian Molasse Basin, in Piller W. E. \& RASSER M. W. (eds), Paleogene of the Eastern Alps. Österreichisce Akademie der Wissenschaften Schriftenreihe der Erdwissenschaftlichen Kommissionen, Vienna, 14: 671-795.

Harzhauser M., Piller W. E. \& Steininger, F. F. 2002. - CircumMediterranean Oligo - Miocene biogeographic evolution - The gastropods' point of view. Palaeogeography, Palaeoclimatology, Palaeoecology 183: 103-133. https://doi.org/10.1016/S00310182(01)00464-3

Harzhauser M., Mandic O., SchlÖgl J. 2011. - A late Burdigalian bathyal mollusc fauna from the Vienna Basin (Slovakia). Geologica Carpathica 62 (3): 211-231. https://doi.org/10.2478/ v10096-011-0018-7

Harzhauser M. \& Landau B. M. 2016. - A revision of the Neogene Conidae and Conorbidae (Gastropoda) of the Paratethys Sea. Zootaxa 4210 (1): 1-178. https://doi.org/10.11646/ zootaxa.4210.1.1

Harzhauser M., Mandic O., BüyüKmeriç Y., Neubauer T. A., Kadolsky D, LANDAU B. M. 2016. - A Rupelian mangrove swamp mollusc fauna from the Thrace Basin in Turkey. Archiv für Molluskenkunde: International Journal of Malacology 145 (1): 23-58. https://doi.org/10.1127/arch.moll/1869-0963/145/023-058

Harzhauser M., Grunert P., Mandic O., Lukeneder P., García Gallardo Á., Neubauer T. A., Carnevale G., Landau B. M., Sauer R. \& Strauss P. 2018. - Middle and late Badenian palaeoenvironments in the northern Vienna Basin and their potential link to the Badenian Salinity Crisis. Geologica Carpathica 69 (2): 149-168. https://doi.org/10.1515/geoca-2018-0009

HEALY J. 1993. - Transfer of the gastropod family Plesiotrochidae to the Campaniloidea based on sperm ultrastructure evidence. Journal of Molluscan Studies 59 (2): 135-146. https://doi.org/10.1093/ mollus/59.2.135

HERRMANNSEN A. N. 1846-1852. — Indicis generum malacozoorum primordial. Nomina subgenerum, generum, familiarum, tribuum, ordinum, classium: adjectis auctoribus, temporibus, locis systematicis ateque literariis, etymus, synonymis. Praetermittuntur Cirripedia, Tunicata et Rhizopoda. 1-2. T. Fischeri, Cassel: 1-232 (1846); 233-637 (1847) (1); 1-352 (1848); 493-717 (1849); supplement (1852). https://doi.org/10.5962/bhl.title.10147

HøISÆTER T. 2014. — The pyramidellidae (gastropoda, heterobranchia) of Norway and adjacent waters. A taxonomic review. Fauna Norvegica 34: 7-78. https://doi.org/10.5324/fn.v34i0.1672 
HÖRNES M. 1852. — Die fossilen Mollusken des Tertiär-Beckens von Wien. Abhandlungen der Kaiserlich-Königlichen Geologischen Reichsanstalt 3: 43-208.

HÖRNES M. 1855. — Die fossilen Mollusken des Tertiär-Beckens von Wien. Abhandlungen der Kaiserlich-Königlichen Geologischen Reichsanstalt 3: 383-460.

HÖRNES M. 1856. — Die fossilen Mollusken des Tertiär-Beckens von Wien. Abhandlungen der Kaiserlich-Königlichen Geologischen Reichsanstalt 3: 461-736.

Houbrick R. S. 1991. - Systematic review and functional morphology of the mangrove snails Terebralia and Telescopium (Potamididae; Prosobranchia). Malacologia 33 (1-2): 289-338.

Houbrick R. S. 1993. - Phylogenetic relationships and generic review of the Bittinae (Prosobranchia: Cerithioidea). Malacologia 35: 261-313.

IREDALE T. 1915. - Some more misused molluscan generic nomes. Proceedings of the Malacological Society of London 11: 291-309. https://biodiversitylibrary.org/page/ 15715842

İsLAMOĞLU Y. 2004. - Kasaba Miyosen Havzasinin Gastropoda Faunasi (Bati Toroslar, GB Tütkiye). Bulletin of the Mineral Research Exploration 128: 137-170.

İSLAMOĞLU Y. 2008. - Molluscan biostratigraphy and paleoenvironmental reconstruction of Oligocene deposits in the Denizli and Kale-Tavas subbasins (SW Turkey). Geodiversitas 30 (2): 261-285.

İsLAMOĞLU Y. \& TANER G. 2003. - The paleogeographic and paleoecologic characteristics of the Miocene aged molluscan fauna in Antalya and Kasaba Basins (west-central Taurus, SW Turkey). Bulletin of the Mineral Research Exploration 126: 11-42.

JANSSEN A. W. 1984. - Mollusken uit het Mioceen van WinterswijkMiste. Een inventarisatie, met beschrijvingen en afbeeldingen van alle aangetroffen soorten. Koninklijke Nederlandse Natuurhistorische Vereniging, Nederlandse Geologische Vereniging \& Rijkmuseum van Geologie en Mineralogie, Amsterdam, 451 p.

JansSEn R., Zuschin M. \& BAal C. 2011. - Gastropods and their habitats from the northern Red Sea (Egypt: Safaga). Part 2: Caenogastropoda: Sorbeoconcha and Littorinimorpha. Annalen des Naturhistorischen Museums Wien Serie A 113: 373-509.

KADOLSKY D. 1995. - Stratigraphie und Molluskenfaunen von "Landschneckenkalk" und "Cerithienschichten" im Mainzer Becken (Oberoligozaen bis Untermiozaen?), 2: Revision der aquatischen Mollusken des Landschneckenkalkes. Archiv für Molluskenkunde: International Journal of Malacology 124 (1-2): 1-55. https://doi.org/10.1127/arch.moll/124/1995/1

KANO Y. \& KASE T. 2004. - Genetic exchange between anchialine cave populations by means of larval dispersal: The case of a new gastropod species Neritilia cavernicola. Zoologica Scripta 33: 423-437. https://doi.org/10.1111/j.0300-3256.2004.00159.x

KanO Y., Kase T. \& KubO H. 2003. - The unique interstitial habitat of a new neritiliid gastropod, Neritilia littoralis. Journal of the Marine Biological Association of the United Kingdom 83: 835-840. https://doi.org/10.1017/S0025315403007860h

Kilias A., VamVaka A., Falalakis G., Sfeikos A., Papadimitriou E., GKarlaouni C. \& Karakostas B. 2015. - The Mesohellenic Trough and the Paleogene Thrace Basin on the Rhodope Massif, their Structural Evolution and Geotectonic Significance in the Hellenides. Journal of Geology \& Geophysics 4: 1-17. https://doi. org/10.4172/2329-6755.1000198

KobeLt W. 1879. - Illustrirtes Conchylienbuch. Vol. 2 (6). Bauer \& Raspe, Nürnberg: 145-176. https://doi.org/10.5962/bhl. title.11092

KoKshoorn B., Goud J., Gittenberger E. \& Gittenberger A. 2007. - Epitoniid parasites (Gastropoda, Caenogastropoda, Epitoniidae) and their host sea anemones (Cnidaria, Actiniaria, Ceriatharia) in the Spermonde archipelago, Sulawesi, Indonesia. Basteria 71: 33-56.

Koskeridou E. 1997. - The Neogene Turritellidae of Greece. PhD thesis. National and Kapodistrian University of Athens, Publications of the Faculty of Geology. Gaia 3, 210 p.
Koskeridou E., Drinia H. \& Moissette P. 2009. — Marginal marine benthic assemblages in a highly variable setting (Late Pliocene, Rhodes Island, Greece). 9th Symposium on Oceanography \& Fisheries, 3-16 May Patras, Greece, Proceedings 1: 91-94.

Koskeridou E., Giamali C., ANTONarakou A., Kontakiotis G. \& KARAKITSIOS V. 2017. — Early Pliocene gastropod assemblages from the eastern Mediterranean (SW Peloponnese, Greece) and their palaeobiogeographic implications. Geobios 50 (4): 267-277. http://dx.doi.org/10.1016/j.geobios.2017.06.003

KOVÁCS Z. \& ViCIÁN Z. 2016. — A new Egerian (Upper Oligocene Lower Miocene) gastropod fauna from the Esztergom Bsain (NE Transdanubia, Hungary). Földtani Közlöny 146 (3): 233-256.

Kowalke T. \& HarzHaUser M. 2004. - Early ontogeny and palaeoecology of the mid-Miocene rissoid gastropods of the Central Paratethys. Acta Palaeontologica Polonica 49: 111-134.

LAMARCK J. B. P. A. DE M. 1811. - Détermination des espèces de Mollusques testacés: continuation du genre ovule, tarrière, ancillaire et olive. Annales du Muséum national d'Histoire naturelle de Paris 16 (1810): 300-328. https://biodiversitylibrary.org/ page/3547431

Landau B. M., Marquet R. \& Grigis M. 2004. — The early Pliocene Gastropoda (Mollusca) of Estepona, southern Spain. Part 2. Orthogastropoda, Neotaenioglossa. Palaeontos 4: 1-108.

Landau B. M., Silva C. M. DA \& MaYORAL E. 2011. - The lower Pliocene gastropods of the Huelva Sands Formation, Guadalquivir Basin, southwestern Spain. Palaeofocus 4: 1-90.

Landau B. M., Harzhauser M., İslamoĞLU Y. \& Da Silva C. M. 2013. - Systematics and palaeobiogeography of the gastropods of the middle Miocene (Serravallian) Karaman Basin, Turkey. Cainozoic Research 11-13: 3-584.

Landau B. M. \& LaFollette P. I. 2015. - The Pyramidellidae (Mollusca: Gastropoda) from the Miocene Canature Formation of Venezuela. Cainozoic Research 15 (1-2): 13-54

Landau B. M., Ceulemans L. \& Dinengen F. van 2018. - The upper Miocene gastropods of northwestern France, 2. Caenogastropoda. Cainozoic Research 18 (2): 17-368.

Latal C., Piller W. E. \& Harzhauser M. 2006. — Small-scaled environmental changes: indications from stable isotopes of gastropods (Early Miocene, Korneuburg Basin, Austria). International Journal of Earth Sciences 95: 95-106. https://doi.org/10.1007/ s00531-005-0510-3

LESPORT J. F. \& CAHUZAC B. 2005. - Découverte des sables à mactres de la base du Burdigalien à Martillac (Nord Aquitaine; SW France); données paléontologiques. Annales de Paléontologie 91: 83-116. https://doi.org/10.1016/j.annpal.2004.11.004

LINDEN J. VAN DER 1998. - The Metaxiinae dredged by the CANCAP expeditions, with the new species Metaxia carinapex and Metaxia hapax from the Cape Verde Islands (Gastropoda, Heteropoda: Triphoridae). Basteria 61: 115-122.

Lozouet P. 1986. - Redéfinition des genres Potamides et Pirenella (Gastropoda, Prosobranchia) à partir des espèces actuelles et fossiles: implications phylétiques et biogéographiques. Annales de Paléontologie 72 (3): 163-210.

LozoueT P. 1999. — Nouvelles espèces de gastéropodes (Mollusca: Gastropoda) de l'Oligocène et du Miocène inférieur de l'Aquitaine (Sud-Ouest de la France). Part. 2. Cossmanniana 6: 61-102.

Lozouet P. 2004. — The European Tertiary Neritiliidae (Mollusca, Gastropoda, Neritopsina): Indicators of tropical submarine cave environments and freshwater faunas. Zoological Journal of the Linnean Society 140: 447-467. https://doi.org/10.1111/j.10963642.2003.00099.x

LozoueT P. 2014. - Temporal and latitudinal trends in the biodiversity of European Atlantic Cenozoic gastropod (Mollusca) faunas. A base for the history of biogeographic provinces. Carnets de Géologie 14: 273-314.

LozOUET P. 2015. - New species of gastropods (Mollusca: Gastropoda) from the Oligocene and the Lower Miocene of Aquitaine (Southwestern France). Cossmanniana 17: 15-84. 
Lozouet P., Lesport J. F. \& Renard P. 2001. — Révision des Gastropoda (Mollusca) du Stratotype de l'Aquitanien (Miocène Inf.): site de Saucats "Lariey", Gironde, France. Cossmanniana h.s.: 1-189.

LOZOUET P. \& MAESTRATI P. 2012. — Le contenu paléontologique. Mollusques, in Lozouet P. (ed.) Stratotype Stampien. Muséum national d'Histoire naturelle Paris, Biotope, Mèze: 239-297 (Patrimoine géologique; 4).

Lozouet P. \& LondeIX L. 2014a. - Mollusques, in LondeIX L. (ed.), Stratotype Aquitanien. Muséum national d'Histoire naturelle, Paris, Biotope, Mèze: supplementary material CD-rom (Patrimoine géologique; 5).

LOZOUET P. \& LONDEIX L. 2014b. - Melongena lainei (Mollusca, Gastropoda), l'emblème de la Réserve naturelle géologique de Saucats - La Brède: quelles significations paléobiologiques?, in LondeIX L. (ed.), Stratotype Aquitanien. Muséum national d'Histoire naturelle, Paris, Biotope, Mèze: 285-293 (Patrimoine géologique; 5).

Malaquias M. A. E., Mackenzie-Dodds J., Bouchet P., GosLINER T. \& REID D. G. 2009. - A molecular phylogeny of the Cephalaspidea sensu lato (Gastropoda: Euthyneura): Arthitectibranchia redefined and Runinacea reinstated. Zoologica Scripta 38: 23-41. https://doi.org/10.1111/j.1463-6409.2008.00354.x

MAlatesta A. 1974. - Malacofauna pliocenica Umbra. Memorie per Servire alla Carta Geologica d'Italia 13: 1-498.

Mandic O., Harzhauser M., Schlaf J., Piller W. E., Schuster F., WielandT-Schuster U., Nebelsick J. K., KrOH A., RÖGL F. \& BASSANT P. 2004. - Palaeoenvironmental reconstruction of an epicontinental flooding - Burdigalian (Early Miocene) of the Mut Basin (Southern Turkey). Courier Forschungsinstitut Senckenberg 248: 57-92.

Manganelli G., Spadini V. \& Cianfanelli S. 2004. - The xenophorid gastropods of the Mediterranean Pliocene: The record of the Siena Basin. Bollettino della Società Paleontologica Italiana 43: 409-451.

MARQUET R. 1996. - The family Triphoridae in the Neogene of Belgium (Mollusca, Gastropoda). Bulletin de l'Institut royal des Sciences naturelles de Belgique, Sciences de la Terre 66: 137-149.

MARQuet R. 1998. - Three Cerithiopsis species, new for the Miocene of Belgium (Cerithiopsidae, Prosobranchia: Gastropoda). Basteria 62:35-41. http://natuurtijdschriften.nl/record/597127

Marquet R., LenaerTS J., KarneKamp C. \& SMith R. 2008. The molluscan fauna of the Borgloon formation in Belgium (Rupelian, Early Oligocene). Palaeontos 12: 1-100.

Marshall B. 1978. — Cerithiopsidae (Mollusca: Gastropoda) of New Zealand, and a provisional classification of the family. New Zealand Journal of Zoology 5 (1): 47-120. https://doi.org/10.10 80/03014223/1978/10423744

MARTENS E. VON 1878. - Mollusca Section. Zoological Record for 1876 13: 1-62. https://biodiversitylibrary.org/page/51296732

Martins R., Sampaio L., Quintino V. \& Rodrigues A. M. 2014. - Diversity, distribution and ecology of benthic molluscan communities on the Portuguese continental shelf. Journal of Sea Research 93: 75-89. https://doi.org/10.1016/j.seares.2013.11.006

Mavridis A., Kelepertzis A., Tsaila-Monopolis S., SKourTsiKorONEOU V. \& MoOres H. 1985. - Geological Map of Greece, scale 1:50 000, Knidi Sheet. Institute of Geology and Mineral Exploration, Athens.

Moissette P., Koskeridou E., Drinia H. \& Cornée J.-J. 2016. Facies associations in warm-temperate siliciclastic deposits: insights from early Pleistocene eastern Mediterranean (Rhodes, Greece). Geological Magazine 153 (1): 61-83. https://doi.org/10.1017/ S0016756815000230

MolluscaBase 2018. - Retusa T. Brown, 1827. Accessed through: World Register of Marine Species at: http://www.marinespecies. org/aphia.php? $\mathrm{p}=$ taxdetails\&id $=138432$ on 2018-06-18

Moths H., Albrecht F. \& Stein G. 2010. — Die Molluskenfauna (Hemmoorium, Untermiozän) aus der Kiesgrube Krinke bei Werder (Nordwest-Niedersachsen). Palaeofocus 3: 1-155.
Neubauer T., Harzhauser M., Mandic O., Kroh A. \& GeorgoPOULOU E. 2016. - Evolution, turnovers and spatial variation of the gastropod fauna of the late Miocene biodiversity hotspot Lake Pannon. Palaeogeography, Palaeoclimatology, Palaeoecology 442: 84-95. https://doi.org/10.1016/j.palaeo.2015.11.016

NeviLl G. 1885. - Hand list of Mollusca in the Indian Museum, Calutta. 2. Gastropoda. Prosobranchia-Neurobranchia (contd.). J. White, London: x + 306 p. https://doi.org/10.5962/bhl. title.11957

Nielsen J. K., Hanken N.-M., Nielsen J. K. \& Hansen 2006. Biostratigraphy and palaeoecology of the marine Pleistocene of Rhodes, Greece: Scleractinia, Serpulidae, Mollusca and Brachiopoda. Bulletin of Geoscience 81 (3): 173-196. https://doi. org/10.3140/bull.geosci.2006.03.173

OLIVERIO M. 1995. - Larval development and allozyme variation in the East Atlantic Columbella (Gastropoda, Prosobranchia, Columbellidae). Scientia Marina 59: 77-86.

Orbigny A. D' 1852. - Prodrome de paléontologie stratigraphique universelle des animaux mollusques et rayonnés, faisant suite au cours élémentaire de paléontologie et de géologie stratigraphique, 3. Victor Masson, Paris: 1-196, index 1-189. https://doi.org/10.5962/ bhl.title. 45605

Oskars T. R., Bouchet P. \& Malaquias M. A. E. 2015. - A new phylogeny of the Cephalaspidea (Gastropoda: Heterobranchia) based on expanded taxon sampling and gene markers. Molecular Phylogenetics and Evolution 89: 130-150. https://doi.org/10.1016/j. ympev.2015.04.011

ÖZTÜrk B., DoĞan A., Bitlis-Bakir B. \& SAlman A. 2014. Marine molluscs of the Turkish coasts: An updated checklist. Turkish Journal of Zoology 38: 832-879. https://doi.org/10.3906/ zoo-1405-78

Pälike H., Norris R. D., Herrle J. O., Wilson P. A., CoXall H. K., Lear C. H., Shackleton N. J., Tripati A. K. \& WADE B. S. 2006. - The heartbeat of the oligocene climate system. Science 314: 1894-1898. https://doi.org/10.1126/ science. 1133822

Peñas A., Templado J. \& Martínez J. L. 1996. — Contribución al conocimiento de los Pyramidelloidea (Gastropoda: Heterostropha) del Mediterráneo español. Iberus 14: 1-82. https://biodiversitylibrary.org/page/35323778

Peñas A. \& Rolán E. 1999. - La familia Pyramidellidae Gray, 1840 (Mollusca, Gastropoda, Heterostropha) en Africa Occidental. 4. Los géneros Megastomia, Odostomia, Noemiamea y Syrnola. Iberus suplemento 5: 1-150. https://biodiversitylibrary. org/page/35660090

PeŃAS A. \& RolÁn E. 2010. - Deep water Pyramidelloidea of the tropical South Pacific: Turbonilla and related genera, in GOFAS S. (ed.), Tropical Deep Sea Benthos volume 26-Deep-water Pyramidelloidea of the Tropical South Pacific: Turbonilla and related genera. Muséum national d'Histoire naturelle, Paris, 436 p. (Mémoires du Muséum national d'Histoire naturelle; 200).

Peñas A. \& Rolán E. 2017. - Deep Water Pyramidelloidea from the Central and South Pacific. The Tribe Chrisallidini. Estación de Ciencias Mariñas de Toralla, Universidade de Vigo, Vigo, 412 p.

Peyrot A. 1925. - Conchologie néogénique de l'Aquitaine. Actes de la Société linnéenne de Bordeaux 77 (2): 51-194. https://biodiversitylibrary.org/page/47952687

Peyrot A. 1928. - Conchologie néogénique de l'Aquitaine. Édition in- $8^{\circ}$, Extrait des Actes de la Société Linnéenne de Bordeaux 5 (2): 207-465.

Peyrot A. 1932. - Conchologie néogénique de l'Aquitaine. Actes de la Société linnéenne de Bordeaux 84 (1): 5-128.

Pimenta A. D. \& ABSAlÃo R. S. 2004. - Review of the genera Eulimastoma Bartsch, 1916 and Egina Dall \& Bartsch, 1904 (Mollusca, Gastropoda, Pyramidellidae) from Brazil. Zoosystema 26 (2): $157-173$

PLAZIAT J. C. 1995. - Modern and fossils mangroves and mangals: their climatic and biogeographic variability, in BOSENCE D. W. 
J. \& Allison P. A. (eds), Marine Palaeoenvironmental Analysis from Fossils. Geological Society, London, Special Publication 83: 73-96. https://doi.org/10.1144/GSL.SP.1995.083.01.05

PONDER W. F. 1983. - A revision of the Recent Xenophoridae of the world and of the Australian fossil species (Mollusca, Gastropoda). Australian Museum Memoir 17: 1-126. https://doi.org /10.3853/j.0067-1967.17.1983.393

PONDER W. F. 1984. - A review of the genera of the Iravadiidae (Gastropoda: Rissoacea) with an assessment of the relationships of the family. Malacologia 25: 21-71. http://www.biodiversitylibrary.org/page/13145132

Puillandre N., Bouchet P., Duda T. F. JR., Kauferstein S., KoHN A. J., Oliveira B. M., Watkins M. \& Meyer C. 2014. - Molecular phylogeny and evolution of the cone snails (Gastropoda, Conoidea). Molecular Phylogenetics and Evolution 78: 290-303. https://doi.org/10.1016/j.ympev.2014.05.023

Reid D. G., Dyal P., Lozouet P., Glaubrecht M. \& Williams S. T. 2008. - Mudwhelks and mangroves: the evolutionary history of an ecological association (Gastropoda: Potamididae). Molecular Phylogenetics and Evolution 47: 680-699. https://doi. org/10.1016/j.ympev.2008.01.003

ReIch S., Wesselingh F. \& RENEMA W. 2014. — A highly diverse molluscan seagrass fauna from the early Burdigalian (early Miocene) of Banyunganti (south-central Java, Indonesia). Annalen des Naturhistorischen Museums Wien 116: 5-130. https://www. jstor.org/stable/43923072

ROBBA E. 2013. - Tertiary and Quaternary fossil pyramidelloidean gastropods of Indonesia. Scripta Geologica 144: 1-191. http:// www.scriptageologica.nl/13/nr144/a01

RUEDA J. L. \& SALAS C. 2007. - Trophic dependence of the emerald neritid Smaragdia viridis (Linnaeus, 1758) on two seagrasses from European coasts. Journal of Molluscan Studies 73 (2): 211-214. https://doi.org/10.1093/mollus/eym011

SACCO F. 1888. - Sopra alcuni Potamides del bacino terziario del Piemonte. Bollettino della Società Malacologica Italiana 13: 87-122. https://biodiversitylibrary.org/page/39283548

SACCO F. 1890. - I molluschi dei terreni terziari del Piemonte e della Liguria, 6. Volutidae, Marginellidae, Columbellidae. Memorie della Reale Accademia delle Scienze di Torino 2 (40): 295-368.

SACCO F. 1892. - I molluschi dei terreni terziarii del Piemonte e della Liguria, 12. (Pyramidellidae (fine), Ringiculidae, Solariidae e Scalariidae (agg.)). Bollettino dei Musei di Zoologia ed Anatomia comparata della Reale Universita di Torino 7 (121): 3-87. https:// biodiversitylibrary.org/page/12779608

SACCO F. 1895a. - I molluschi dei terreni terziari del Piemonte e della Liguria, 17. (Cerithiidae, Triforidae, Cerithiopsidae e Diastomidae). Bollettino dei Musei di Zoologia ed Anatomia comparata della Reale Universita di Torino 10 (197): 71-74. https:// biodiversitylibrary.org/page/12934950

SACCO F. 1895b. - I molluschi dei terreni terziarii del Piemonte e della Liguria, 18. (Melaniidae, Littorinidae, Fossaridae, Rissoidae, Hydrobiidae, Paludinidae e Valvatidae). Bollettino dei Musei di Zoologia ed Anatomia comparata della Reale Universita di Torino 10 (206): 75-78. https://biodiversitylibrary.org/ page/ 12934472

SACCO F. 1896. - I molluschi dei terreni terziarii del Piemonte e della Liguria, 19. (Turritellidae e Mathildidae). Bollettino dei Musei di Zoologia ed Anatomia comparata della Reale Universita di Torino 11 (267): 79-81. https://biodiversitylibrary.org/page/11822455

SACCO F. 1897. - I Molluschi dei terreni terziarii del Piemonte e della Liguria, 22. Gasteropoda (fine), Amphineura, Scaphopoda. Bollettino dei Musei di Zoologia ed Anatomia comparata della Reale Universita di Torino, 128 p. https://biodiversitylibrary. org/page/11838153

SACCO F. 1904. - I Molluschi dei terreni terziari del Piemonte e della Liguria, 30. Aggiunte e correzioni (con 1400 figure). Considerazioni generali. Indice generale dell'opera. C. Clausen, Torino, $203+$ xxxvi p., 32 pls.
SChaffer F. X. 1912. - Das Miocän von Eggenburg. Die Fauna der ersten Mediterranstufe des Wiener Beckens und die gologischen Verhältnisse der Umgebung des Manhartsberges in Niederösterreich. Abhandlungen der Kaiserlich-Königlichen Geologischen Reichsanstalt 22: 127-193. https://biodiversitylibrary.org/ page/51319455

Schander C., Halanych K. M., Dahlgren T. \& Sundberg P. 2003. - Test of the monophyly of Odostomiinae and Turbonilliinae (Gastropoda, Heterobranchia, Pyramidellidae) based on $16 S$ mtDNA sequences. Zoologica Scripta 32: 243-254. https:// doi.org/10.1046/j.1463-6409.2003.00112.x

Sosso M. \& ANGelo Dell' B. 2010. - I fossili del Rio Torsero. Editing Marginalia, Cartotectonica Beusi srl, Prato, 95 p.

Stein G., Moths H., Albrecht F., HaveKost U. \& Fehse D. 2016. Revision der Miozänen Molluskenfauna (Hemmoorium) von Werder bei Achim (Nordwest-Niedersachsen). Palaeofocus 5: 1-289.

STRAUSz L. 1966. — Die Miozän-Mediterranen Gastropoden Ungarns. Akadémiai Kiadó, Budapest, 692 p.

Strong E. E., Gargominy O., Ponder W. F. \& Bouchet P. 2008. - Global diversity of gastropods (Gastropoda; Mollusca) in freshwater. Hydrobiologia 595: 149-166. https://doi. org/10.1007/s10750-007-9012-6

SymeOnidis N. 1966. - Das Neogen von Ost Creta. Annales géologiques des Pays helléniques XVI: 249-314.

SymONDS M. \& TRACEY S. 2014. — Neritilia (Gastropoda, Neritopsina, Neritiliidae): pushing back the timeline. Cainozoic Research 14 (1): 3-7.

ŠVAGROVSKÝ J. 1984. — Gastropoda, Euthyneura, Opisthobranchia des oberen Badeniens aus der Umgebung von Borský Miculáš (NO-Teil des Wiener Beckens) und ihre stratigraphische Bedeutung. Geologica Carpathica 35: 165-194.

TĂMAS A., TĂMAS D. M. \& POPA M. V. 2013. — Badenian Small Gastropods from Lăpugiu De Sus (Făget Basin, Romania). Rissoidae Family. Acta Palaeontologica Romaniae 9 (1): 57-66.

Thompson T. E. 1988. — Molluscs: Benthic opisthobranchs (Mollusca: Gastropoda), in KERMACK D. M. \& BARNES R. S. K. (eds), Synopses of the British Fauna (New Series) 8 (Second Edition). E. J. Brill/Dr. W. Backhuys, Leiden, 356 p.

Uribe J., Puillandre N. \& Zardoya R. 2017. - Beyond Conus: Phylogenetic relationships of Conidae based on complete mitochondrial genomes. Molecular Phylogenetics and Evolution 107: 142-151. https://doi.org/10.1016/j.ympev.2016.10.008

Utescher T., Mosbrugger V., Ivanov D. \& Dilcher D. L. 2009. - Present-day climatic equivalents of European Cenozoic climates. Earth Planetary Science Letters 284: 544-552. https:// doi.org/10.1016/j.epsl.2009.05.021

VERMEIJ G. 2017. — Life in the arena: Infaunal gastropods and the Late Phanerozoic expansion of marine ecosystems into sand. Palaeontology 60 (5): 649-661. https://doi.org/10.1111/pala.12310

Vignal L. 1911. - Cerithiidae du Tertiaire supérieur du department de la Gironde. Journal de Conchyliologie 58: 138-186.

Wielandt-Schuster U., Schuster F., HarZHauser M., Mandic O., KrOH A., RÖgi F., Reisinger J., Liebtrau V., Steininger F. F. \& PILLER W. E. 2004. — Stratigraphy and palaeoecology of Oligocene and Early Miocene sedimentary sequences of the Mesohellenic Basin (NW Greece). CFS Courier Forschungsinstitut Senckenberg 248: 1-55. Williams S. T., Donald K. M., Spencer H. G. \& NaKano T. 2010. - Molecular systematics of the marine gastropod families Trochidae and Calliostomatidae (Mollusca: Superfamily Trochoidea). Molecular Phylogenetics and Evolution 54:783-809. https://doi.org/10.1016/j.ympev.2009.11.008

WitTibsChlager L. 1983. - Mesohalina nov. gen. (Potamididae, Gastropoda) aus dem Oligo/Miozän Mitteleuropas. Beiträge zur Paläontologie Österreichs 10: 15-79.

Zachos J. C., Shackleton N. J., Revenaugh J. S., Pälike H. \& Flower B. P. 2001. - Climate Response to Orbital Forcing Across the Oligocene-Miocene Boundary. Science 292: 274-278. https://doi.org/10.1126/science. 1058288 
Zelilidis A., Piper D. J. W. \& Kontopoulos N. 2002. — Sedimentation and basin evolution of the Oligocene-Miocene Mesohellenic basin, Greece. American Association of Petroleum Geologists Bulletin 86: 161-182. https://doi.org/10.1306/61eeda6c-173e$11 \mathrm{~d} 7-8645000102 \mathrm{c} 1865 \mathrm{~d}$

ZilCH A. 1934. - Zur Fauna des Mittel-Miozäns von Kostej (Banat). Typus-Bestimmung und Tafeln zu O. Boettger's Bearbeitungen. Senckenbergiana 16: 193-302.

Zunino M. \& PAVIA G. 2009. — Lower to middle Miocene mollusc assemblages from the Torino hills (NW Italy): synthesis of new data and chronostratigraphical arrangement. Rivista Italiana di paleontologia e Stratigrafia 115 (3): 349-370. https://doi. org/10.13130/2039-4942/6388

Zuschin M., Harzhauser M. \& Mandic O. 2004. - Taphonomy and paleoecology of the Lower Badenian (Middle Miocene) molluscan assemblages at Grund (Lower Austria). Geologica Carpathica 55 (2): 117-128.
Zuschin M., Harzhauser M \& Mandic O. 2005. — Influence of Size-sorting on Diversity Estimates from Tempestitic Shell Beds in the Middle Miocene of Austria. Palaios 20: 142-158. https:// doi.org/10.2210/palo.2003.p03-87

Zuschin M., Harzhauser M. \& Sauermoser K. 2006. Patchiness of local species richness and its implication for large-scale diversity patterns: An example from the middle Miocene of the Paratethys. Lethaia 39 (1): 65-78. https://doi. org/10.1080/00241160600578687

ZUSCHIN M., JANSSEN R. \& BAAL C. 2009. — Gastropods and their habitats from the northern Red Sea (Egypt: Safaga), Part 1: Patellogastropoda, Vetigastropoda and Cycloneritimorpha. Annalen des Naturhistorischen Museums Wien 111A: 73-158.

Zuschin M., Harzhauser M., Hengst B., Mandic O. \& RÖTZEL R. 2014. - Long-term ecosystem stability in an Early Miocene estuary. Geology 42 (1): 7-10. https://doi. org/10.1130/G34761.1 
APPENDIX 1. - Dataset used for the Cluster Analysis figuring all specimens identifiable at least to the family-level.

\begin{tabular}{|c|c|c|c|c|c|c|c|c|}
\hline \multirow[b]{2}{*}{ Species } & \multicolumn{8}{|c|}{ Samples } \\
\hline & $\mathrm{F} 1$ & $\mathrm{~F} 2$ & F3 & $\mathrm{F} 7$ & F8 & $\mathrm{F} 10$ & $\mathrm{~F} 11$ & $\mathrm{~F} 12$ \\
\hline \multicolumn{9}{|l|}{ Gastropods } \\
\hline Melongena lainei & 0 & 0 & 0 & 1 & 0 & 0 & 0 & 0 \\
\hline Vitta picta & 5 & 26 & 2 & 18 & 2 & 2 & 0 & 0 \\
\hline Granulolabium plicatum & 17 & 50 & 28 & 60 & 10 & 1 & 0 & 0 \\
\hline ?Theodoxus sp. 1 & 0 & 1 & 1 & 0 & 0 & 0 & 0 & 0 \\
\hline ?Theodoxus sp. 2 & 0 & 0 & 0 & 0 & 1 & 0 & 0 & 0 \\
\hline Mesohalina margaritacea & 0 & 10 & 0 & 1 & 0 & 0 & 0 & 0 \\
\hline Melanopsis sp. & 0 & 7 & 0 & 1 & 0 & 0 & 0 & 0 \\
\hline Cerithidae sp. & 0 & 2 & 0 & 1 & 0 & 0 & 0 & 0 \\
\hline Neritilia neritinoides & 0 & 17 & 0 & 1 & 0 & 0 & 0 & 0 \\
\hline Rissoidae sp. & 0 & 0 & 0 & 3 & 0 & 0 & 0 & 0 \\
\hline Dizoniopsis sp. & 0 & 0 & 0 & 0 & 0 & 0 & 3 & 0 \\
\hline Terebralia subcorrugata & 0 & 0 & 0 & 2 & 0 & 0 & 0 & 0 \\
\hline Terebralia lignitarum & 0 & 0 & 0 & 2 & 0 & 0 & 0 & 0 \\
\hline Mathilda sp. & 0 & 0 & 0 & 0 & 0 & 1 & 0 & 0 \\
\hline Plesiotrochus fallax & 0 & 0 & 0 & 0 & 0 & 3 & 2 & 0 \\
\hline Xenophora sp. & 0 & 0 & 0 & 0 & 0 & 1 & 0 & 0 \\
\hline Homalopoma acaste n. sp. & 0 & 0 & 0 & 0 & 0 & 3 & 4 & 0 \\
\hline Smaragdia merignacensis & 0 & 0 & 0 & 0 & 0 & 3 & 3 & 1 \\
\hline Turritella turris & 0 & 0 & 0 & 0 & 0 & 4 & 19 & 12 \\
\hline Nodiscala cf. rugatina & 0 & 0 & 0 & 0 & 0 & 0 & 2 & 0 \\
\hline Bittium larrieyense & 0 & 0 & 0 & 0 & 0 & 39 & 230 & 181 \\
\hline Retusa truncatula & 0 & 0 & 0 & 0 & 0 & 0 & 4 & 0 \\
\hline Volvulella acuminata & 0 & 0 & 0 & 0 & 0 & 0 & 3 & 0 \\
\hline Cylichna cf. sublaevis & 0 & 0 & 0 & 0 & 0 & 0 & 4 & 0 \\
\hline Pyrunculus sp. & 0 & 0 & 0 & 0 & 0 & 0 & 4 & 0 \\
\hline Zebinella sp. & 0 & 0 & 0 & 0 & 0 & 0 & 4 & 0 \\
\hline Finella perpusilla & 0 & 0 & 0 & 0 & 0 & 8 & 76 & 16 \\
\hline Triphora (s.l.) sp. & 0 & 0 & 0 & 0 & 0 & 2 & 4 & 0 \\
\hline Metaxia sp. & 0 & 0 & 0 & 0 & 0 & 0 & 2 & 0 \\
\hline Xenophora sp. & 0 & 0 & 0 & 0 & 0 & 1 & 0 & 0 \\
\hline Cerithiopsis (s.l.) sp. 2 & 0 & 0 & 0 & 0 & 0 & 0 & 1 & 0 \\
\hline Gibborissoia varicosa & 0 & 0 & 0 & 0 & 0 & 0 & 12 & 18 \\
\hline Costoanachis terebralis & 0 & 0 & 0 & 0 & 0 & 0 & 3 & 2 \\
\hline Pusia cf. pyramidella & 0 & 0 & 0 & 0 & 0 & 0 & 4 & 0 \\
\hline Athleta rarispina & 0 & 0 & 0 & 0 & 0 & 0 & 1 & 0 \\
\hline Acteon cf. pinguis & 0 & 0 & 0 & 0 & 0 & 3 & 2 & 4 \\
\hline Rissoina subconoidea & 0 & 0 & 0 & 0 & 0 & 3 & 0 & 0 \\
\hline Alvania amphitrite $\mathrm{n} . \mathrm{sp}$. & 0 & 0 & 0 & 0 & 0 & 2 & 15 & 0 \\
\hline Alvania transiens & 0 & 0 & 0 & 0 & 0 & 3 & 5 & 0 \\
\hline Paroxystele orientalis & 0 & 0 & 0 & 0 & 0 & 0 & 1 & 0 \\
\hline Cerithium sp. & 0 & 0 & 0 & 0 & 0 & 0 & 3 & 2 \\
\hline Jujubinus sp. & 0 & 0 & 0 & 0 & 0 & 0 & 1 & 0 \\
\hline Ringicula minor & 0 & 0 & 0 & 0 & 0 & 0 & 44 & 9 \\
\hline Pyramidella plicosa & 0 & 0 & 0 & 0 & 0 & 0 & 3 & 0 \\
\hline 'Odostomia' (s.l.) sp. 1 & 0 & 0 & 0 & 0 & 0 & 0 & 1 & 0 \\
\hline 'Odostomia' (s.l.) sp. 2 & 0 & 0 & 0 & 0 & 0 & 0 & 2 & 0 \\
\hline Megastomia sp. 1 & 0 & 0 & 0 & 0 & 0 & 0 & 3 & 0 \\
\hline Megastomia sp. 2 & 0 & 0 & 0 & 0 & 0 & 0 & 7 & 0 \\
\hline Brachystomia sp. & 0 & 0 & 0 & 0 & 0 & 0 & 3 & 0 \\
\hline Pyramistomia aliakmoni $\mathrm{n}$. sp. & 0 & 0 & 0 & 0 & 0 & 0 & 3 & 0 \\
\hline Parthenina sp. 1 & 0 & 0 & 0 & 0 & 0 & 0 & 2 & 0 \\
\hline Parthenina sp. 2 & 0 & 0 & 0 & 0 & 0 & 0 & 2 & 0 \\
\hline ?Syrnola sp. & 0 & 0 & 0 & 0 & 0 & 0 & 3 & 0 \\
\hline Turbonilla (s.l.) sp. 1 & 0 & 0 & 0 & 0 & 0 & 0 & 3 & 0 \\
\hline Turbonilla (s.l.) sp. 2 & 0 & 0 & 0 & 0 & 0 & 0 & 1 & 0 \\
\hline Turbonilla (s.l.) sp. 3 & 0 & 0 & 0 & 0 & 0 & 0 & 2 & 0 \\
\hline Turbonilla (s.I.) sp. 4 & 0 & 0 & 0 & 0 & 0 & 0 & 12 & 0 \\
\hline Naticidae sp. & 0 & 0 & 0 & 0 & 0 & 5 & 15 & 10 \\
\hline Nassarius (s.l.) sp. & 0 & 0 & 0 & 0 & 0 & 3 & 8 & 5 \\
\hline Capuloidea sp. & 0 & 0 & 0 & 0 & 0 & 2 & 4 & 0 \\
\hline ?Lautoconus sp. & 0 & 0 & 0 & 0 & 0 & 0 & 1 & 0 \\
\hline Conus (s.l.) sp. & 0 & 0 & 0 & 0 & 0 & 0 & 1 & 0 \\
\hline Seila sp. & 0 & 0 & 0 & 0 & 0 & 0 & 1 & 0 \\
\hline Eulima sp. & 0 & 0 & 0 & 0 & 0 & 0 & 4 & 0 \\
\hline
\end{tabular}




\begin{tabular}{|c|c|c|c|c|c|c|c|c|}
\hline \multirow[b]{2}{*}{ Species } & \multicolumn{8}{|c|}{ Samples } \\
\hline & $\mathrm{F} 1$ & $\mathrm{~F} 2$ & F3 & $\mathrm{F} 7$ & F8 & F10 & F11 & $\mathrm{F} 12$ \\
\hline \multicolumn{9}{|l|}{ Bivalves } \\
\hline Chama sp. & 0 & 0 & 0 & 0 & 0 & 5 & 8 & 6 \\
\hline Arca sp. & 0 & 0 & 0 & 0 & 0 & 5 & 10 & 6 \\
\hline Acar sp. & 0 & 0 & 0 & 0 & 0 & 3 & 1 & 1 \\
\hline Glycymeris sp. & 0 & 0 & 0 & 0 & 0 & 2 & 9 & 7 \\
\hline Pectinidae sp. & 0 & 0 & 0 & 0 & 0 & 6 & 10 & 5 \\
\hline Ostreidae sp. & 0 & 0 & 0 & 0 & 0 & 8 & 15 & 6 \\
\hline Lucinidae sp. & 0 & 0 & 0 & 0 & 0 & 2 & 10 & 4 \\
\hline Nucula sp. & 0 & 0 & 0 & 0 & 0 & 1 & 0 & 0 \\
\hline Cardiidae sp. & 0 & 0 & 0 & 0 & 0 & 5 & 10 & 6 \\
\hline
\end{tabular}

\section{LIST OF FAMILIES}

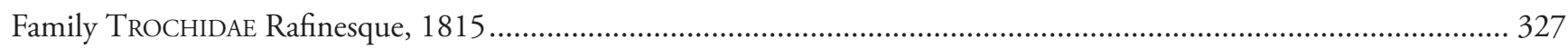

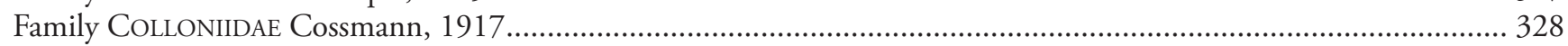

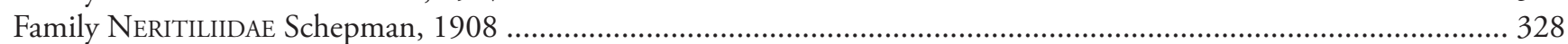

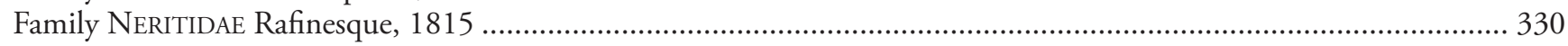

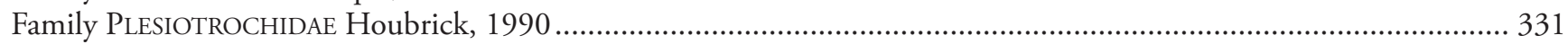

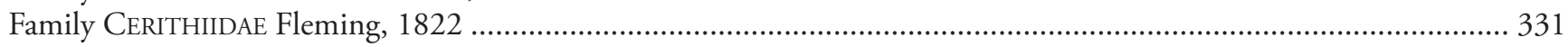

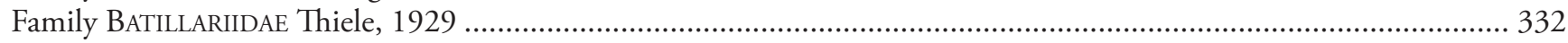

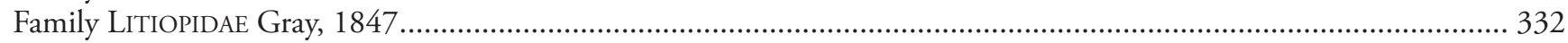

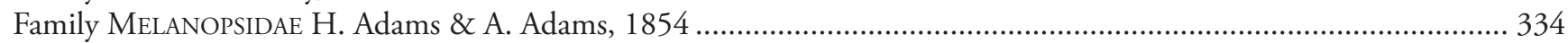

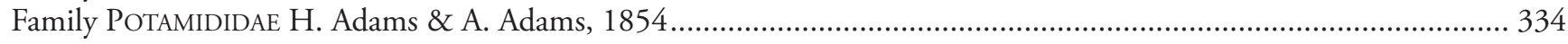

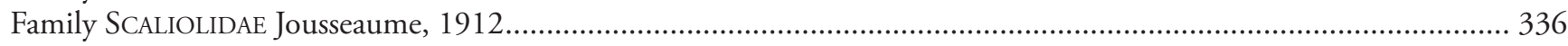

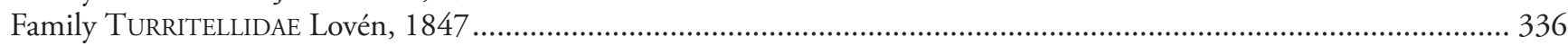

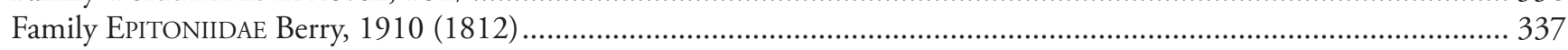

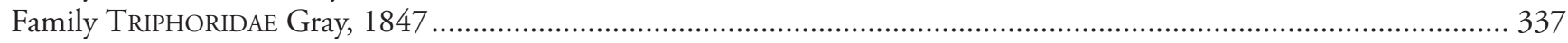

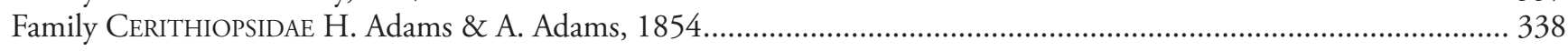

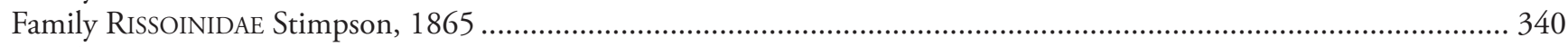

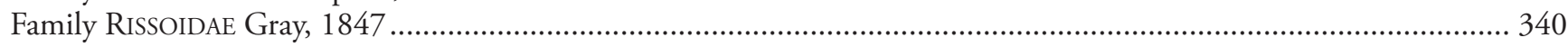

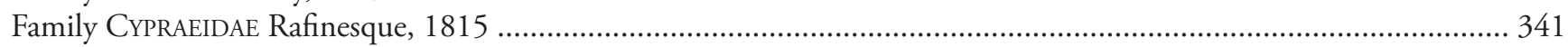

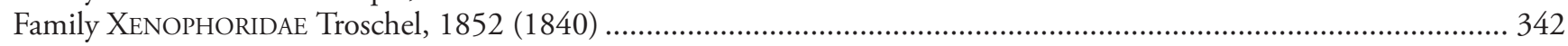

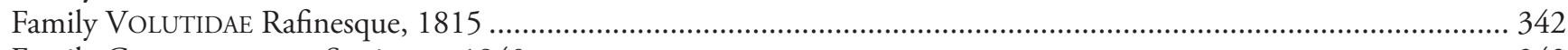

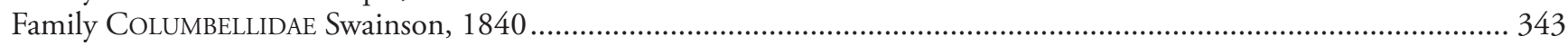

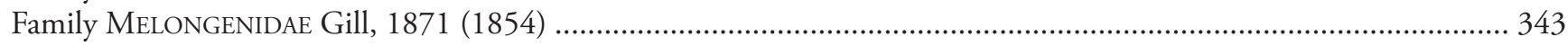

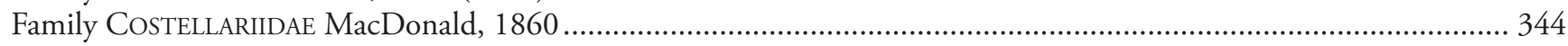

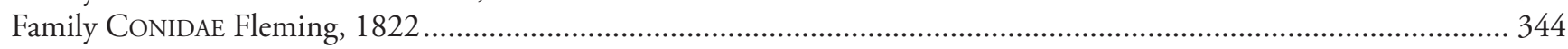

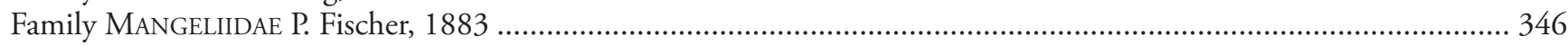

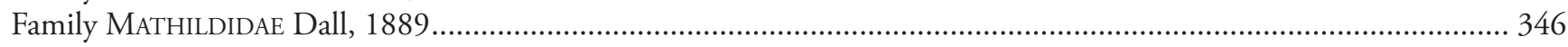

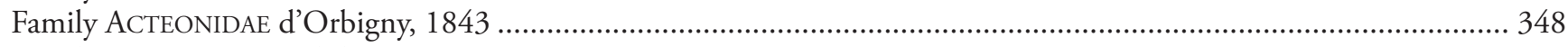

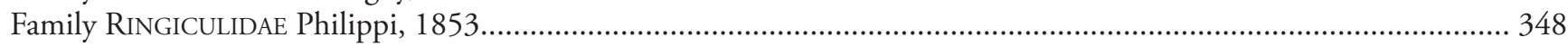

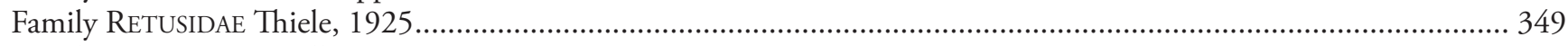

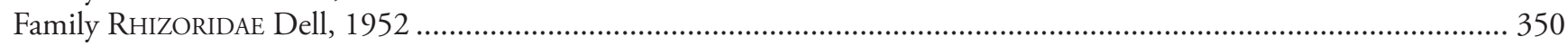

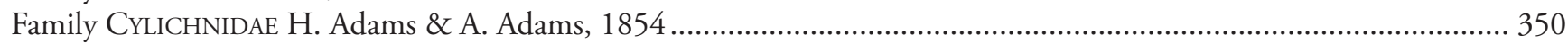

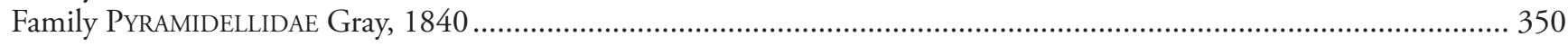

